\title{
Modification of C-seco Taxoids Through Ring Tethering and Substituent Replacement Leading to Effective Agents Against Tumor Drug Resistance Mediated by $\beta$ III-Tubulin and P-gp Overexpressions
}

\author{
Yong Tang, ${ }^{1}$ Javier Rodríguez-Salarichs, ${ }^{2}$ Yu Zhao, ${ }^{1}$ Pei Cai, ${ }^{1}$ Juan Estévez-Gallego, ${ }^{2}$ Francisco \\ Balaguer-Pérez, ${ }^{2}$, Mariano Redondo Horcajo ${ }^{2}$, Daniel Lucena-Agell, ${ }^{2}$ Isabel Barasoain, ${ }^{2} \mathrm{~J}$. \\ Fernando Díaz, ${ }^{2}$ Wei-Shuo Fang ${ }^{1, *}$ \\ ( ${ }^{1}$ State Key Laboratory of Bioactive Substances and Functions of Natural Medicines, Institute of \\ Materia Medica, CAMS \& PUMC, 2A Nan Wei Road, Beijing 100050, China; ${ }^{2}$ Centro de \\ Investigaciones Biológicas, Consejo Superior de Investigaciones Científicas, Ramiro de Maeztu 9, \\ 28040 Madrid, Spain) \\ *Corresponding author. E-mail: wfang@imm.ac.cn
}




\begin{abstract}
:
In our efforts to improve the efficacy of taxane-based microtubule (MT) stabilizing agents against tumor drug resistance mediated by multiple mechanisms, two clinically relevant factors were focused: i.e., P-glycoprotein and $\beta$ III-tubulin overexpression. Based on the structure of C-seco taxoid IDN5390 which was believed to more selectively interact with $\beta$ III-tubulin than paclitaxel, we prepared a series of C-seco taxoids bearing various 7,9-O-linkages and/or different substituents at $\mathrm{C} 2$ and $\mathrm{C} 13$ positions. Some of them exhibited much more potent binding affinity to MTs and cytotoxicity than their $\mathrm{C}$-seco parent compounds in drug resistant cells with both mechanisms. SAR analysis indicated that $\mathrm{C} 2$ modifications significantly enhanced MT binding but less cytotoxicity to some extent whereas 7,9-linkage and C13 modifications enhance cytotoxicity more efficiently than improve MT binding. These observations illustrate a better translation of molecular binding effect to cellular activity by $\mathrm{C}$ ring closure and $\mathrm{C} 13$ modification than $\mathrm{C} 2$ modification in $\mathrm{C}$-seco taxoids.
\end{abstract}




\section{Introduction}

The past twenty years have witnessed the success of taxane-based anticancer drug paclitaxel and docetaxel (Figure 1), both of which belong to the first known chemotype of microtubule stabilizing agents (MSAs). ${ }^{1,2}$ However, their clinical uses were severely restricted by intrinsic and acquired drug resistance.

Many efforts have been made to develop new generation of taxane-based drugs since late $1990 \mathrm{~s}^{3}$, among which the most prominent achievement is the FDA approval of cabazitaxel (Figure 1) in 2010 for the treatment of metastatic hormone-refractory prostate cancer, in combination with prednisone. Although the therapeutic effect of drug resistant tumor by cabazitaxel was ascribed, at least in part, to that this compound is a poor substrate for P-glycoprotein (P-gp, MDR1, ABCB1), many other drug candidates targeting P-gp overexpression mechanism did not achieve the expected efficacy in clinical trials ${ }^{4}$. Hence, it was proposed that only targeting P-gp overexpression is not sufficient to fight drug resistant tumors, because many other drug resistance mechanisms may operate simultaneously in patients.

Various tumor drug resistance mechanisms toward MSAs have been revealed ${ }^{5}$, however only a small part of them confirmed clinically, including overexpression of P-gp ${ }^{6}$ or $\beta I I I-t u b u l i n^{7-10}$. Besides, tumor drug resistance may also arise from the overexpression of other ABC transporters (e.g. BCRP, MRP and LRP) as well as $\beta$-tubulin mutations, which have been demonstrated in animal models. Although its prediction value in clinics was acclaimed in a paper published in $2001^{11}$, $\beta$-tubulin mutation as a clinically relevant drug resistance factor was questioned by a variety of following studies ${ }^{12,13}$.

Alternative strategies were explored recently to find more effective taxane-based antitumor agents to overcome drug resistance. These efforts include simultaneously targeting multiple ATP binding cassette (ABC) transporter proteins ${ }^{14}$, or $\beta$ III isotype of tubulin ${ }^{15,16}$.

Multiple targeting agents have gained more attention in recent years, as they could be more effective in treating complex diseases involving in multiple genes ${ }^{17,18}$. Our strategy is to discover novel antitumor agent simultaneously targeting clinically 
relevant drug resistance factors such as P-gp and $\beta$ III-tubulin overexpression.

This strategy has been applied successfully to the discovery of a high affinity taxane LX2-32C (Figure 1) in our labs, which is effective both in drug resistant cancer cells with P-gp overexpression and bearing $\beta$-tubulin mutations ${ }^{19}$ and also in drug resistant breast cancer MX-1/T xenograft mice ${ }^{20,21}$.

Based on the initial success, we tried to extend our efforts to the development of such multitargeting agents, with an emphasis on $\beta$ III-tubulin overexpression, a clinically relevant drug resistance mechanism which was recognized only in recent years and thus under-explored. In addition to be involved in the drug resistance toward taxane-based MSAs, $\beta$ III-tubulin has also been identified as a survival factor in several types of cancers, thus conferring resistance to various anticancer agents, such as MT destabilizing agents (MDAs) and DNA interacting agents ${ }^{7}$.

Some small molecules targeting tubulin have been designed to overcome drug resistance mediated by $\beta$ III-tubulin overexpression, but most of them failed to show excess potency than $\operatorname{taxol}^{22,23}$. Ixabepilone $\left(\operatorname{Ixempra}^{\circledR}\right)$, the only marketed MSA other than taxanes, exhibiting better cytotoxicity in $\beta$ III-tubulin overexpressing tumor cells than in sensitive cells ${ }^{24}$. A semi-synthetic taxane Yg-3-46a from our labs, which is effective against tumor drug resistance mediated by both P-gp and $\beta$ III-tubulin overexpression, has also been reported very recently ${ }^{25}$. However, both compounds were found to be effective against $\beta$ III-tubulin-mediated drug resistance serendipitously rather than by intentional design.

C-seco taxoid IDN5390 ${ }^{15}$ (Figure 1) is another molecule which was reported to be more cytotoxic than paclitaxel in $\beta$ III-tubulin overexpressing A2780TC3 cell, but is much less active than paclitaxel in drug sensitive counterpart A2780 ovarian cancer cell. The reason for more potent cytotoxicity of IDN5390 in BIII-tubulin overexpressing A2780TC3 cell was proposed as the opening of $\mathrm{C}$ ring which enhances its structural flexibility so as to adopt a more suitable conformation upon binding to $\beta$ III-tubulin based on molecular modeling studies ${ }^{26}$, whereas paclitaxel is not able to do so due to the rigidity of its C-ring. However, the same structure characteristics also accounts for the significantly decreased activity of IDN5390 in 
drug sensitive tumor cells, corresponding to the poorer binding to $\beta$-I tubulin, the major isotype of tubulin in cells.

Figure 1

In this study, we proposed to tether the opened $\mathrm{C}$ ring in $\mathrm{C}$-seco paclitaxel to reduce its flexibility so as to enhance the binding to $\beta$-I tubulin, while hopefully retaining the flexibility of $\mathrm{C}$ ring to some extent for its better binding to $\beta$ III-tubulin, in order to find modified taxanes effective in both drug sensitive and resistant tumor cells ( $\beta$ III-tubulin and/or P-gp overexpression mechanism) on a rational basis.

To fulfill this task, we synthesized 7,9-O-linked $\mathrm{C}$-seco taxoids together with further modifications at $\mathrm{C} 2$ and $\mathrm{C} 13$ positions, tested their anticancer activity and modeled their interactions with $\beta \mathrm{I}$ - and $\beta$ III-tubulin. Here we report such results for these antitubulin agents.

\section{Results}

As shown in Scheme 1, our synthesis began with the preparation of 2'-butyldimethylsilyl-10-deacetylpaclitaxel 3, which was oxidized by copper(II) diacetate to furnish $\mathbf{4}$ as a mixture of two epimers. The resulting mixture 4 was treated with L-selectride at $-20^{\circ} \mathrm{C}$ in THF to afford C-seco taxoid $\mathbf{5}$ as a key intermediate. This simplified synthetic route is developed on the basis of synthesis of C-secocephalomannine $^{27}$, with an improved overall yield.

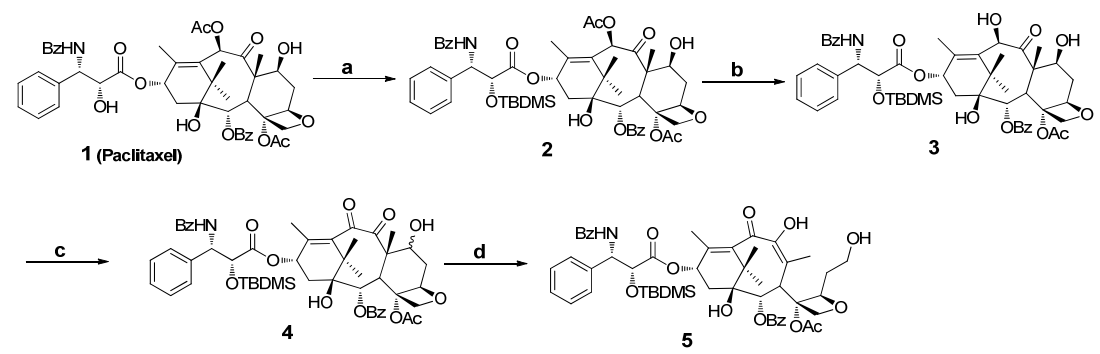

Scheme 1. Reagents and conditions: (a) tert-butylchlorodimethylsilane, imidazole, DMF, 4h, rt; (b) $\mathrm{NH}_{2} \mathrm{NH}_{2} \cdot \mathrm{H}_{2} \mathrm{O}, \mathrm{C}_{2} \mathrm{H}_{5} \mathrm{OH}, 2 \mathrm{~h}, \mathrm{rt}, 92.7 \%$ (for two steps); (c) $\mathrm{Cu}(\mathrm{OAc})_{2}, \mathrm{CH}_{3} \mathrm{OH}, 12 \mathrm{~h}, \mathrm{rt}, 92.8 \%$; (d) L-selectride, THF, $10 \mathrm{~min},-20^{\circ} \mathrm{C}, 54.6 \%$. 
With 7-hydroxyl-9-enol compound 5 at hand, we designed to introduce allyl or homoallyl groups, facilitating the further ring cyclization through metathesis. After several unsuccessful attempts to derivatize both 7- and 9-OH with allyl group simultaneously, we turned to take advantage of the acidity of 9-OH (an enol group) to be at first alkylated, using corresponding alkyl bromides and potassium carbonate in DMF. Compounds 6a-c with 9-O-alkylated groups bearing terminal alkenes were successfully obtained in this way. Then $7-\mathrm{OH}$ in 6a-c was alkylated by allyl trifluoromethanesulfonate in the presence of 2,6-di-tert-butyl-4-methylpyridine in dichloromethane ${ }^{28}$ to afford 7,9-O-dialkylated taxoids 7a-c.

Ring closure metathesis was performed in the presence of Grubbs' 2nd generation catalyst in 1,2-dichloroethane, furnishing desired macrocyclic taxoids 8a-c as well as $\mathbf{8 g}$. The trans-isomers were obtained in all cases and as major or sole products in most cases, whereas $\mathbf{8 g}$ was the only cis-isomer obtained as a minor product when a five atom 7,9-O-linkage was used. After the removal of 2'-O$t$-butyldimethylsilyl protecting group in $\mathbf{8 a - c}$ and $\mathbf{8 g}$, macrocyclic taxoids $\mathbf{1 a - c}$ and $\mathbf{1 g}$ with unsaturated 7,9-O-linkages were afforded.

Catalytic hydrogenation of $\mathbf{8 a}$ and $\mathbf{8 c}$ over $\mathrm{Pd} / \mathrm{C}$ in ethyl acetate afforded corresponding macrocyclic taxoids 9a and 9c. After desilylation at $\mathrm{C} 2$ ' $-\mathrm{OH}, \mathbf{1 d}$ and $\mathbf{1 f}$ bearing saturated linkers were obtained. Taxoid $\mathbf{8 b}$ was successively desilylated at $\mathrm{C} 2{ }^{\prime}$ and hydrogenated over $\mathrm{Pd} / \mathrm{C}$ in ethanol to furnish 1e bearing a saturated linker (scheme 2).

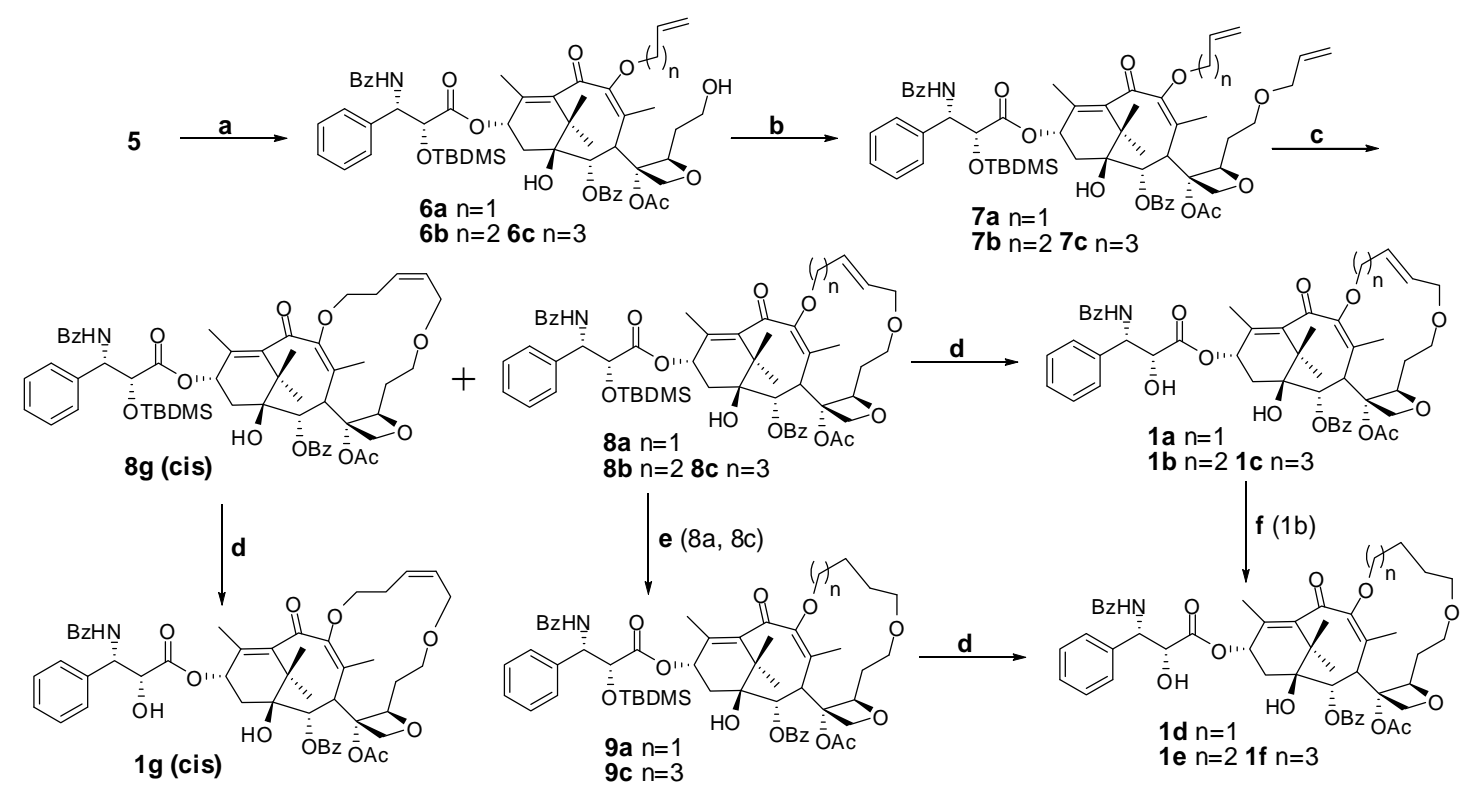


Scheme 2. Reagents and conditions: (a) 3-bromo-1-butene, $\mathrm{K}_{2} \mathrm{CO}_{3}$, KI, DMF, 3h, rt, 76.4\% (6a), 4-bromo-1-butene, $\mathrm{K}_{2} \mathrm{CO}_{3}$, KI, DMF, 4h, rt, 60.2\% (6b), 5-bromo-1-butene, $\mathrm{K}_{2} \mathrm{CO}_{3}$, $\mathrm{KI}$, DMF, 4h, rt, 59.7\% (6c); (b) allyl trifluoromethanesulfonate, 2,6-di-tert-butyl-4-methylpyridine, dichloromethane, $2 \mathrm{~h},-38^{\circ} \mathrm{C} \sim-49^{\circ} \mathrm{C}, 29.7 \%$ (7a), 38.2\% (7b), 27.7\% (7c); (c) Grubbs' catalyst 2nd, 1,2-dichloroethane, $3.5 \mathrm{~h}, 42^{\circ} \mathrm{C}, 43.2 \%$ (8a), Grubbs' catalyst $2 \mathrm{nd}, 1,2$-dichloroethane, $4 \mathrm{~h}, 55^{\circ} \mathrm{C}$, $24.7 \%(8 \mathbf{b}+\mathbf{8 g})$, Grubbs' catalyst 2nd, 1,2-dichloroethane, $4 \mathrm{~h}, 44^{\circ} \mathrm{C}, 40.6 \%(\mathbf{8 c})$; (d): HF/Py, $\mathrm{CH}_{3} \mathrm{CN}, 30 \mathrm{~h}, \mathrm{rt}, 61.8 \%$ (1a), $72.6 \%$ (1b), 58.6\% (1c), 41.1\% (1d) (for two steps) $49.8 \%$ (1f) (for two steps), 77.2\% (1g); (e) Pd/C, AcOEt, rt; (f) Pd/C, $\mathrm{C}_{2} \mathrm{H}_{5} \mathrm{OH}$, rt, 45.4\% (1e).

C-seco-taxol $\mathbf{1 h}$ reported by Appendino ${ }^{29}$ and two derivatives $\mathbf{1 i}$ and $\mathbf{1 j}$ were synthesized as reference compounds from key intermediate $\mathbf{5}$ according to the following methods respectively: 2'-O-desilylation yielded $\mathbf{1 h}$; 9-O-methylation by using iodomethane in DMF and then 2'-O-desilyation furnished 1i; 7-O-methylation by using methyl trifluoromethanesulfonate in dichloromethane and then 2'-O-desilyation afforded C-seco taxoid $\mathbf{1} \mathbf{j}$.

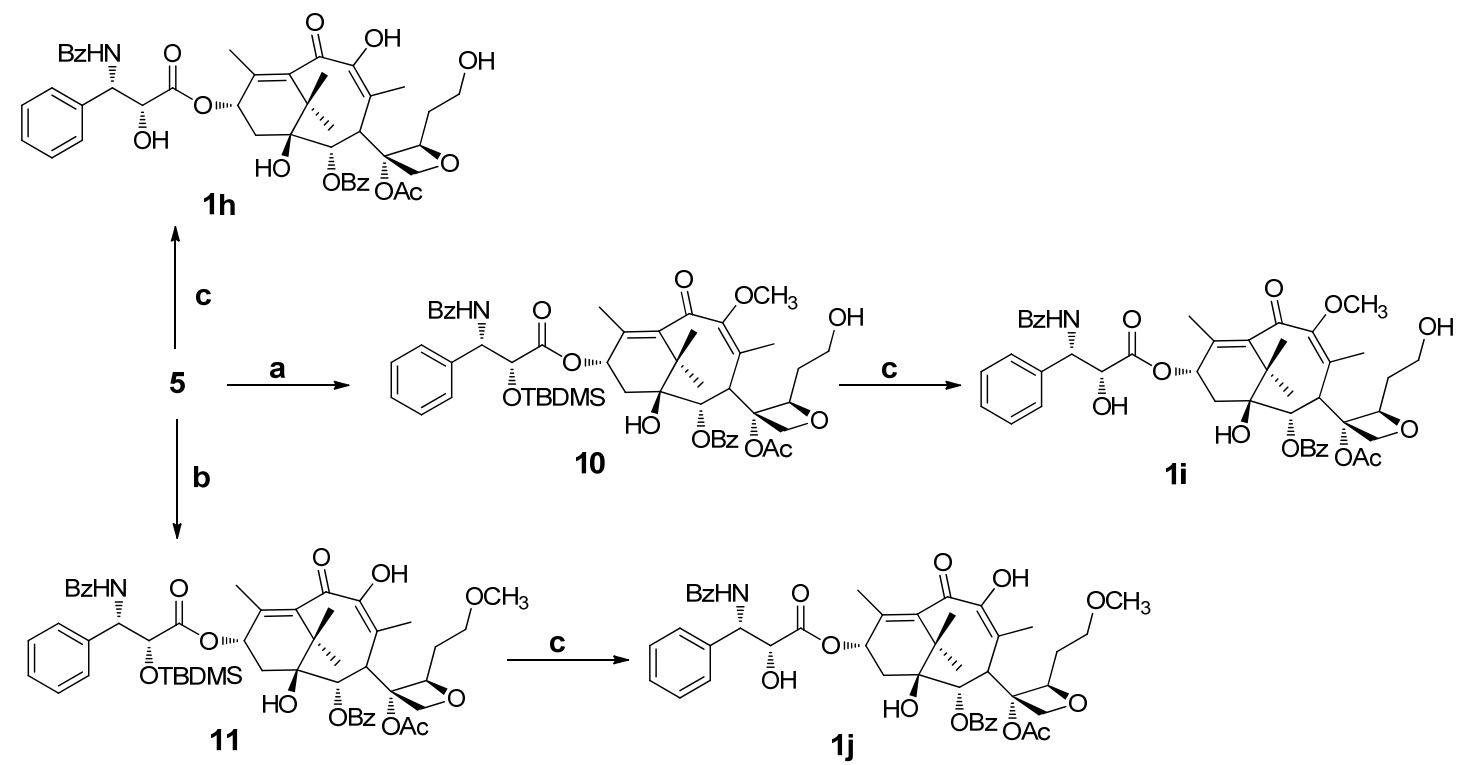

Scheme 3. Reagents and conditions: (a) iodomethane, $\mathrm{K}_{2} \mathrm{CO}_{3}$, DMF, 4h, rt, 69.0\%; (b) methyl trifluoromethanesulfonate, 2,6-di-tert-butyl-4-methylpyridine, dichloromethane, $0^{\circ} \mathrm{C} \sim \mathrm{rt}, 4 \mathrm{~h}, \mathrm{rt}$, $22.6 \%$; (c) $\mathrm{HF} / \mathrm{Py}, \mathrm{CH}_{3} \mathrm{CN}, 30 \mathrm{~h}, \mathrm{rt}, 49.1 \%$ (1h), 70.3\%(1i), 73.3\%(1j)

Taxoids 1a-i were then first evaluated for their cytotoxicity in Hela cancer cells and corresponding drug-resistant Hela- $\beta$ III cells, exhibiting stable $\beta I I I$ overexpression through gene transfection (Table 1). 
All 7,9-O-linked C-seco taxoids 1a-g exhibited significant activity enhancement against Hela and Hela- $\beta$ III tumor cell lines compared with C-seco paclitaxel derivative $\mathbf{1 h}$, an analogue of IDN5390. The R/S values ( IC $_{50}$ in drug resistant cells / $\mathrm{IC}_{50}$ in drug sensitive cells) of all macrocyclic taxoids $\mathbf{1 a - g}$ are lower than that of $\mathbf{1 h}$ or paclitaxel. Although the reference $\mathrm{C}$-seco taxoid $\mathbf{1 h}$ is much less active than paclitaxel both in drug sensitive Hela and resistant Hela- $\beta$ III cells, the significantly improved activity of the tethered analogs 1a-g over their parent $\mathrm{C}$-seco taxoids demonstrated the tethering strategy is successful in improving the cytotoxicity against tumor cells overexpressing $\beta$ III tubulin.

It was observed that the length and saturation degree of the linker influenced the binding affinity as well as the cytotoxicity of these macrocyclic taxoids. As shown in Table 1, the 7,9-O-linked C-seco taxoids bearing 4-5 atom linkers are generally more active, among which 1a, $\mathbf{d}$, e, and $\mathbf{g}$ exhibiting 30-60 times more potent cytotoxicity than $\mathrm{C}$-seco paclitaxel $\mathbf{1 h}$ in Hela cells and two orders of magnitude more potent than $\mathbf{1 h}$ in Hela- $\beta$ III cells, except $\mathbf{1 b}$ (trans-2-pentene linker) which is less active than other compounds bearing 4-5 atom linkers. When the 6 atom linker was incorporated (1c and 1f), the cytotoxicity against both drug sensitive and resistant cells decreased notably.

It is also interesting to note that methylation at different positions in C-seco taxoids also have differential impact on the cytotoxicity. While the methylation of 7-OH enhanced the activity by approximately 10 times, the methylation of $9-\mathrm{OH}$ slightly reduced the cytotoxicity.

As we have observed that enhancement of binding affinity to MTs could counteract multidrug (MDR) resistance mediated by P-gp overexpression ${ }^{30}$, we are also interested to see if there is any relationship between their interaction with MTs and the cytotoxicity in $\beta$ III-tubulin-mediated drug resistant cells. Although we are not able to draw a conclusion based on such a small number of samples, we did observe that the taxoids with more potent binding to MTs (1e, g) exhibited higher cytotoxicity in drug resistant Hela- $\beta$ III cells, as we had observed in other paclitaxel analogs with C-2, 7, 10, 3' and 3'-N modifications (unpublished results).

Among all the macrocyclic compounds, taxoid 1e exhibited highest MT binding affinity and cytotoxicity. It is 150 -fold more potent than $\mathbf{1 h}$ in Hela cells and 58-fold more potent than $\mathbf{1 h}$ in Hela- $\beta$ III cells. Compared to taxol, 1e showed slightly higher 
cytotoxicity than taxol in Hela- $\beta$ III cells and slightly lower cytotoxicity in Hela cells.

Since overexpression of P-gp is also a key factor responsible for taxol resistance, three 7,9-O-tethered $\mathrm{C}$-seco taxoids $\mathbf{1 a}, \mathbf{1 e}, \mathbf{1 g}$ with highly activity against Hela and Hela- $\beta$ III cells were tested for their growth inhibitory activity on the human ovarian cancer cell line A2780 and corresponding drug-resistant cell line A2780AD over-expressing P-gp. As shown in Table 1, all three compounds displayed better activities against A2780AD cell lines than $\mathbf{1 h}$ and lower $\mathrm{R} / \mathrm{S}$ values than that of paclitaxel (the effect of the . As same as we observed in Hela and Hela- $\beta$ III tumor cells, taxoid 1e is the best among the series. In drug resistant A2780AD cells, 1e was 2 3-fold more potent than paclitaxel and displayed a much lower R/S ratio (55) than paclitaxel (759), in line with our previous findings that taxanes with enhanced binding affinity to MTs exhibited better activity in P-gp overexpression-mediated multidrug resistance ${ }^{19,30}$.

\section{$\underline{\text { Table } 1}$}

To confirm the enhanced cytotoxicity of 1e in Hela- $\beta$ III cells is related to its better interaction with $\beta$ III-tubulin, we measured the cytotoxicity in the absence and the presence of $\beta$ III siRNA in this cell line. It was found that in the presence of siRNA, the cytotoxicity for paclitaxel against Hela- $\beta$ III cells was improved (4 times) more than that for 1e (1.5 times), demonstrating that $1 \mathrm{e}$ itself could reverse the $\beta$ III tubulin-mediated drug resistance to some extent.

\section{$\underline{\text { Table } 2}$}

In order to understand the molecular basis for the differences in binding of 7,9-tethered C-seco taxoids with $\beta \mathrm{I}$ - and $\beta$ III-tubulin isotypes, we built models for paclitaxel, IDN5390 and C-seco taxoids 1a-1h, in complex with $\beta$ I-tubulin in dimers, as well as with $\beta$ III-tubulin whose structure has been constructed from homology with $\beta \mathrm{I}$ - tubulin (1JFF). Taxoids were docked into the binding site, and the different possible conformers were explored using MC/MM algorithm while the protein-ligand interactions were optimized (Figure S1). 
The models were validated by computing the binding Gibbs free energies of the compounds bound to $\beta I$-tubulin, which were compared with the association constants measured (Table S1, Figure S3, S6 \& S7). The binding Gibbs free energy of the ligands bound to a $\beta$ III subunit was also calculated (Table S1, Figure S5 \& S6). The linear fit between experimental and calculated binding constants has an $\mathrm{R}^{2}$ equal to 0.938 (Figure S3). This value, for our purpose, can be considered acceptable. It indicates that the interactions of these compounds in the binding sites found by the modeling are in agreement with the experimental data.

In the complex of taxoids with $\beta \mathrm{I}$-and $\beta \mathrm{III}$-tubulins (Figure S1U), the position of paclitaxel is shifted to the eastern part of the binding site in $\beta$ III-tubulin as compared with the position in $\beta$ I-tubulin. This shift is induced by the S277A change in the $\beta I I I$ isotype, which causes a rearrangement and an increased flexibility of the M-loop. Therefore, the changes S277A and C241S, two residues which are close to the taxane binding site, resulted in the displacement of the protein interaction surface of the binding pocket towards the east part (Figure S4), rather than direct changes in the interaction of taxoids within the binding site in $\beta I I I$ isotype. Subsequently, no obvious difference of the interaction network of residues and ligands in the binding pocket can be observed. Nevertheless, the changes in $\beta$ III-tubulin (C241S and S277A) led to slight modifications in hydrogen bonding network (Figure S5) which change the binding contacts of $\mathrm{C}$-seco taxoids with these two isotypes.

The in silico atomic interaction of the ligands with the protein indicates that the western part of C-seco taxoids with larger volumes than paclitaxel is responsible for the decrease in their binding energies (Figure S2). In addition, when comparing the binding energies of paclitaxel, $\mathbf{1 h}, \mathbf{1 a}$ and $\mathbf{1 e}$ in their free and bound forms to $\beta I I I$, we observed that the energy of atoms in the western part showed significant differences between free and bound states $(-\Delta \Delta \mathrm{Gb}=5-10 \mathrm{~kJ} / \mathrm{mol})$, while the atoms in the rest part of ligands have similar contributions to the binding energy. In paclitaxel and C-seco taxoid $\mathbf{1 h}$ (Figures S2A and S2B), the western zone increases its energy in bound form to $\beta \mathrm{III}$, which results in an unfavorable contribution to the binding Gibbs free energy. Oppositely, the 7,9-O-linked C-seco taxoids 1a and 1e have favorable 
differences in the bound form to $\beta$ III with respect to the free ligand due to the ring closure, suggesting that they bind much tighter to $\beta$ III-tubulin. According to the modeling 7,9-O-linked $\mathrm{C}$-seco taxoids with larger volumes than $\mathrm{C}$-seco taxoids could induce a strong stabilization effect of the S7-H9 loops with the adjacent subunits ${ }^{31,32}$, leading to higher microtubule stabilization and thus enhanced cytotoxicity.

In addition, the larger molecular size of 7,9-O-linked C-seco taxoids could be contributed to the stabilizing effect of those compounds due to enhanced hydrophobicity, but this is not a dominant factor in the binding event.

All above observations indicate that the improvement of cytotoxicity in drug resistant cancer cells mediated by $\beta$ III overexpression can be realized by the enhancement of binding affinity of MTs through cyclization of opened C-ring. In addition, with the knowledge that enhanced binding affinity of taxane-site ligands to MTs could counteract drug resistance mediated by P-gp overexpression ${ }^{19,30}$, we sought to further enhance the cytotoxicity against tumor drug resistance mediated by both $\beta I I I$ and P-gp overexpression mechanisms, through modifying other positions in taxane to enhance the binding affinity to MTs.

C2 position in taxane has been known to play a critical role in the interaction with tubulin, and some $\mathrm{C} 2$ modifications (e.g. replacement of $\mathrm{C} 2$ benzoyloxy by $m$-azido-benzoyloxy group) could enhance binding affinity more than 400 times $^{30}$. Hence we introduced $m$-azido benzyloxy into $\mathrm{C} 2$ position to afford $\mathrm{C}$-seco taxoid $\mathbf{1 k}$ and 7,9-O-tethered C-seco taxoid $\mathbf{1 l}$ (supplemental materials).

Figure 2

Taxoid 1k bearing 2-( $m$-azido)benzyloxy group did exhibit higher binding potency to MT than its corresponding C-seco taxoid $\mathbf{1 h}$ bearing 2-benzyloxy group as expected. From the structural point of view the enhanced binding affinity is due to the mesomeric effect produced by the azide group, increasing the electron density on the benzene and resulting in a stronger interaction with H229 (positively charged under physiological condition) (Figure 3D). We performed additional calculations to understand the importance of this interaction in the association energy of compounds 
to tubulin. First, the classically calculated free energy of the interaction between H229 and the m-azidobenzoate is $28 \pm 1 \mathrm{~kJ} / \mathrm{mol}$, being in strength comparable to a strong H-bond. A quantum mechanical study was then used to describe the nature of interactions. Figure 4 shows the HOMO (A) and LUMO (B) orbitals of the interaction $\mathrm{H} 229$ and the $m$-azido benzoate, in which it can be seen that HOMO is located completely on the m-azido-benzoate, while LUMO orbital is localized on the H229 ring. The low distances between orbitals and their spatial dispositions make possible electronic transitions from HOMO to LUMO, resulting in tighter interactions and causing an enhanced binding Gibbs free energy for the azide substituted compounds (Table S1).

\section{Figure 3}

However, the ring cyclization of C-seco taxoid bearing 2-( $m$-azido)benzyloxy group (1k) did not further enhance the binding affinity to MTs (Table 3, 1l versus 1k). In order to compare the effect of the compounds in the same cell line (Hela) but resistant by $\mathrm{p}-\mathrm{Gp}$ overexpression, the compounds $1 \mathbf{k}$ to $\mathbf{1 0}$ were also evaluated in KB-3-1 (HeLa cells) derived from a cervical carcinoma and KB-V1 resistant by over-expressing P-gp. For cytotoxicity, $\mathrm{IC}_{50} \mathrm{~s}$ for $\mathbf{1 k}$ and $\mathbf{1 1}$ are comparable in drug sensitive A2780, Hela and KB cell lines, whereas $1 \mathbf{l}$ is significant more active than $\mathbf{1 k}$ in drug resistant $\mathrm{A} 2780 \mathrm{AD}$, Hela- $\beta \mathrm{III}$ and $\mathrm{KB}-\mathrm{V} 1$ cells.

In a recent report ${ }^{13}$, C-seco taxoid IDN5390 derivatives bearing proper C-2 modifications exhibited more potent cell killing ability in drug resistant tumor cells A2780TC3 harboring overexpressed BIII-tubulins. As IDN5390 is a C3'-modified analog of $\mathbf{1 h}$ and the proper modification at this position also known to improve the binding of taxanes to MTs, we decided to further explore simultaneous C-3' and C-2 modifications.

Taxoid 1o, a derivative of IDN5390 (1m) bearing C2 modification was synthesized together with IDN5390 itself and its known derivative SB-CST-10101(1n) ${ }^{16}$ (supplemental materials). 
It could be seen (Table 3) that $\mathrm{C}-13$ modifications (including $\mathrm{C}-3$ ' replacement of phenyl with 2-butanyl, and 3'N-Bz replacement with Boc) resulted in slight enhancement of binding affinity (1m versus $\mathbf{1 h})$, whereas simultaneous C-13 and C-2 modifications enhance it further by 20 -fold (1n versus $\mathbf{1 h}$ ).

\section{$\underline{\text { Table } 3}$}

Interestingly, the C3'-modified analog 1m (IDN5390) possessing less MT binding affinity, exhibited comparable cytotoxicity in two drug sensitive tumor cell lines to its $3^{\prime}-\mathrm{Ph}$ counterpart $\mathbf{1 k}$ and much more potent activity in all three drug-resistant tumor cell lines. The introduction of $m-\mathrm{N}_{3}$ and $m$-OMe substituents into C-2 benzoate in $\mathbf{1 m}$ did potentiate binding affinity to a large extent, but not cytotoxicity in most cell lines (10 vs. 1m), while 3'-isobutanyl C-seco taxoid 1n exhibited more potency in all drug resistant Hela- $\beta$ III, KB-V1 and A2780AD cells.

Among all C-seco taxoids, 11, bearing 2-(m-azido)benzoyl and 7,9-O(trans-butenyl) tether, and 1n, bearing 3'-butanyl and 2-(m-azido)benzoyl, are the most potent in all three pairs of drug sensitive and resistant cell lines.

In order to better understand the ability of our synthesized taxoids for promoting microtubule polymerization, the critical concentrations of microtubule assembly induction power (Table 4) and the time course of tubulin assembly (Figure 6) for taxoids 1k-o and paclitaxel were measured, all taxoids behave as microtubule assembly inducers allowing the assembly of microtubules in the conditions of the experiment. As shown in Figure 6, taxoids $\mathbf{1 1}$ and $\mathbf{1 n}$ promoted tubulin polymerization and reached to a plateau at a faster rate compared to paclitaxel. At the plateau, all the taxoids except 10 showed higher absorbance at $350 \mathrm{~nm}$ under the same concentration compared to paclitaxel, and the absorption curves could keep stable. These indicated higher potency of taxoids $\mathbf{1 k - n}$ in promoting tubulin polymerization and the ability of 10 to promote microtubule assembly. The data of critical concentrations in microtubule assembly induction power assay in table 4 also suggested all synthesized taxoids except 10 exhibited stronger induction power in microtubule polymerization than paclitaxel. All above results are in agreement with the most potent cytotoxicity for taxoids $\mathbf{1 1}$ and $\mathbf{1 n}$ in the series. 


\section{$\underline{\text { Table } 4}$}

\section{Figure 5}

Compounds 1k-o were tested for their effect on the cell cycle of Hela and Hela- $\beta$ III cells, in order to confirm that the structure modifications and the cell viability results described for this set of compounds correspond with the expected cytotoxic effect related to the interaction with tubulin/MT. The concentrations needed to obtain maximal accumulation of the cell cycle at $\mathrm{G}_{2} / \mathrm{M}$ were determined and compared with those required for paclitaxel to produce the same effect. We observed (Figure 6) that all these tested compounds arrest the cell cycle at $\mathrm{G}_{2} / \mathrm{M}$, thus confirming their cytotoxic effects are exerted by blocking cell division.

\section{$\underline{\text { Figure } 6}$}

The DNA content distribution of the Hela- $\beta$ III cells in the experiment nicely confirm those observed from the cytotoxicity data. While paclitaxel requires $35 \mathrm{nM}$ to obtain maximal accumulation of tetraploid cells (with a significant fraction of cells still diploid), compounds $11,1 \mathrm{~m}$ and $1 \mathrm{n}$ induced an almost complete accumulation of tetrapoid cells at concentrations lower than this required by paclitaxel for the same effect, thus confirming the good effect of the C-seco taxoids $\mathbf{1 m}$ and $\mathbf{1 n}$ on the resistant cells and the maintenance of the good properties in the 7,9-O-linked C-seco taxoid 11.

Finally, in order to find the molecular reasons for the higher activity on $\beta$ III tubulin, the molecular fingerprints for C-seco taxoids were obtained from a QSAR model, build employing the cytotoxicities (pIC50) measured for each compound on Hela and Hela- $\beta$ III cells and projected into the atoms of the chemical structures. The model allows to cluster the taxoids $\mathbf{1 a - h}, \mathbf{1 k}$ and $\mathbf{1 l}$, allowing us to evaluate their structural similarities and differences and to predict fingerprints which correlate with the activities of ligands.

The taxanes clustered in five different groups, the most populated one comprises the taxanes with the ring closed while the rest of groups comprise just one taxane. 
From the four taxanes out of the main cluster, paclitaxel has the most divergent structure followed by $\mathbf{1 k}$ and $\mathbf{1 h}$ (ring opened ligands). The clustering indicates that the ring closure and opening and the azide-substitution are the main structural identity factors among this set of molecules (Figure S8).

To understand how these two chemical identities affect taxoids cytotoxicities in the cells, the QSAR model was represented onto 2D structures (Figure S9). Considering the $\mathrm{IC}_{50} \mathrm{~S}$ of paclitaxel in Hela and Hela- $\beta$ III as the reference value, we could find that the saturated closed-ring always shows a positive contribution to the activity of the compound, both in Hela and Hela- $\beta$ III cells. However, an unsaturated closed ring may have different contributions, the presence of an unsaturated bond in the structure of closed-ring has a negative effect in the cytotoxicity of the compounds in Hela cells, while the same feature has an opposite effect in Hela- $\beta$ III cells, resulting in a positive contribution in cytotoxicity with respect to paclitaxel.

The effect of azide-substitution on the activity of the taxanes in $\beta I-$ and $\beta I I I-$ tubulin dominant cells was further analyzed. In all cases, the presence of the azide group on the $\mathrm{C} 2$ benzoyl group results in an enhancement of the cytotoxicity of taxoids.

\section{Discussion}

Tumor drug resistance has shown to limit the use of MT targeting agents in clinics. In the past two decades, most taxane-based drug candidates failed in phase II clinical trials due to unsatisfactory results on drug resistance, except two marketed MSAs carbazitaxel (paclitaxel analog) and ixabepilone (binding to taxane site) ${ }^{24}$, after paclitaxel and docetaxel were launched to market in 1990s. Numerous drug resistance mechanisms have been documented for MSAs in cells, animals and clinical specimens, among which only $\beta I I I$ isotype and P-gp overexpression mechanisms have been supported by clinical evidences. In this attempt we sought to simultaneously target the above two clinically relevant drug resistance mechanisms.

Starting from a C-seco taxoid which was known to be better in drug resistant tumor cells (high $\beta I I I / \beta$ I ratio) but less active in drug sensitive cells (low $\beta$ III/ $\beta$ I ratio), we hope to modulate the structure to find better molecules in both drug sensitive and 
resistant cells, in another word, better interactions with both $\beta$ III- and $\beta I$ - tubulin isotypes. Besides, we also hope to enable some of them to be more effective in P-gp overexpressed tumor cells through enhancing their binding affinity to MTs, as we demonstrated earlier ${ }^{30}$.

During the discovery of C-seco taxoid IDN5390 and subsequent studies of its derivatives $^{15,16,26,27}$, the tumor cell lines with both overexpressed $\beta I I I$ and P-gp drug resistance mechanisms (e.g. A2780TC3) have been employed to test modified taxanes. By using this kind of drug resistant cell line, it is difficult to discriminate the individual contribution of these two clinically relevant mechanisms. To solve this problem, we took advantage of two pairs of cells in this study, one of which possessing P-gp overexpression (A2780AD) and another having a $\beta$ III overexpression mechanism (Hela- $\beta$ III).

We found in this study that the tethering of 7- and 9-OH with proper linkage (C ring closure) in C-seco taxoids could significantly enhance the binding affinity (as much as 10-fold), and improved the cytotoxicity in both drug sensitive (as much as 60-fold) and in drug resistant cells with both mechanisms (as much as 100-fold).

Meanwhile, C-2 and C-13 (C-3' and 3'-N) modifications were introduced into $\mathrm{C}$-seco taxoids (opened $\mathrm{C}$ ring) as well as 7,9-O-tethered counterparts (closed $\mathrm{C}$ ring). It was found C-2 modification could enhance the binding affinity (10-fold) to a larger extent than the cytotoxicity (2- to 8-fold), whereas C-13 modification causes only slightly better binding affinity (as much as 2-fold) but significantly improved cytotoxicity (as much as 100-fold).

For the ring closed $\mathrm{C}$-seco taxoids, C-2 modification did not enhance binding affinity but improved cytotoxicity further especially in drug resistant cells with both P-gp and $\beta$ III overexpression resistance mechanisms (1l versus $\mathbf{1 k}$ ).

The above observations suggested that the closure of opened $\mathrm{C}$ ring as well as C-13 modifications could result in much more potent cytotoxicity even without similar extent of improvement in binding affinity as C-2 modification, and in another word, that the former two structural modifications could be translated the MT binding ability into cytotoxicity more efficiently than C-2 modification. The cell biology experiments confirmed that the observed cytotoxic effects are due to the interaction of the compounds with the cytoskeleton to block the chromosome segregation.

At molecular level, the more potent activity in $\beta$ III overexpressed cells of 
C-seco taxoid IDN5390 was initially explained as the stronger interaction with the change at 277 position in $\beta$ III isotype than paclitaxe ${ }^{15}$. During the exploration of IDN5390 derivatives, the researchers proposed that two mutations (C241S and S277A) in $\beta$ III may not interact directly with either paclitaxel or C-seco taxoid. Instead, H-bonding of 7-OH of taxoid to Arg284 can be well kept in C-seco when binding to $\beta$ III due to its flexibility ${ }^{16}$.

In our modeling studies, we also noticed that there is no direct contact of paclitaxel and $\mathrm{C}$-seco taxoids (including their 7,9-O-tethered ones) with the two mutations within the taxane binding site, and the better activity of 7,9-O-linked compounds in both cells (high and low $\beta$ III/ $/$ I ratio) could be ascribed to the tethered ring occupying more space in the enlarged binding site in $\beta$ III isotype.

The phenomenon that $\mathrm{C}-13$ modification causes more potent cytotoxicity than binding affinity was also observed previously in some close analogs of paclitaxel $^{33}$. To understand this, we have to consider that there are two components to impact on the cytotoxicity of a compound: (1) The free energy of binding (which is representative of the amount of compound bound at a certain free compound concentration) and (2) the effect of the ligand to MT dyanmics. These two effects are additive or even synergistic to result in the cytotoxicity of a ligand, which means that a ligand with a higher structural impact requires a lower percentage of bound molecules to produce the same effect as another ligand with a higher affinity and a lower structural impact.

The difference of C-seco taxoids $\mathbf{1 n}$ and $\mathbf{1 k}$ which differs just in the C3' side chain exemplifies the above situation. Although $\mathbf{1 n}$ is twice more powerful in binding to tubulin, both ligands are equipotent in Hela cells and $\mathbf{1 k}$ is slightly more powerful in A2780, but 1n is significant more potent in both kind of resistant cells Hela- $\beta I I I$ and A2780AD. The difference is unlikely to be resulted from a change in the free energy of ligand binding of $\mathbf{1 n}$ over $1 \mathbf{k}$ to $\beta$ III-tubulin, since there is no significant changes in their binding pose in $\beta$ I and $\beta$ III binding site but to the difference in their structural effect in tubulin, implying that the change in C3' is significantly important to enhance the toxicity in the resistant cells. This argument is reinforced when $1 \mathbf{k}$ and $\mathbf{1 m}$ are compared, $\mathbf{1 m}$ is a significantly weaker binder to tubulin due to the elimination of the azide group at $\mathrm{C} 2$, but in despite of that is significantly more active in the resistant cells, showing that the enhanced effect of $\mathbf{1 n}$ on resistant cells is not 
due to its higher binding affinity.

The structural effect caused by the C-3' modification of C-seco taxoids may be related to a change of the H-bond between the ligand and R284, resulting in the conformational change of the M-loop. Due to its smaller volume compared with their 7,9-O-tethered analogs, neither $\mathbf{1 k}$ nor $\mathbf{1 n}$ can occupy the space in the binding site forcing the M-loop to be more rigid, however 1n has a weaker interaction with the loop, implying that this loop remains more flexible and has a more open conformation which may affect the lateral contact between the protofilaments and modify the microtubular dynamics. Since the modification in C13 is the one responsible of this change, $1 \mathbf{n}$ is more cytotoxic in $\beta$ III overexpressing cells than $\mathbf{1 k}$.

Besides, we also reasoned why $m$-azido group of 2-benzoate could make a significant contribution of binding affinity to taxane. As early as $1990 \mathrm{~s}^{34}$, introduction of $m$-azido group to 2-benzoate in paclitaxel has been found to be highly active, and its contribution to binding affinity (and cytotoxicity in most cases) has not been surpassed to date. However, the exact reason for such contribution has not been explained. In this article, we proposed the possible reason for this amazing functional group to enhance significantly the interaction with tubulin/MT (more than $20 \mathrm{~kJ} / \mathrm{mol}$ free energy change to the whole molecule by a single substitution).

In addition to the better activity found in the $\beta$ III overexpressed drug resistant Hela- $\beta$ III cells, 7,9-O-linked C-seco taxoids are also more effective than paclitaxel in P-gp overexpressed drug resistant A2780AD cells. Thus, new C-seco taxoids such as 11 or 1n warrant further investigation to combat drug resistance mediated by those two clinically relevant factors. As in patients' tumors are in heterogeneity possessing different drug resistance mechanisms, such molecules counteracting multiple drug resistance mechanisms are expected to exhibit better antitumor activity in vivo.

\section{Experimentals}

\section{Chemical Synthesis}

General Methods: ${ }^{1} \mathrm{H}$ and ${ }^{13} \mathrm{C}$ NMR spectra were measured on Varian 300 , 400, or $500 \mathrm{MHz}$ NMR spectrometers. Mass spectra (ESI) were measured on JEOL Accu TOF CS (JMS T100CS). High-resolution mass spectrometry (HR-MS) spectra were measured on Agilent 1100 Seris LC-MSD-Trap-SL. Reagents were purchased from 
Aldrich and Alfa Aesar Chemical companies. All solvents were purified and dried according to standard procedures, unless otherwise indicated. Reactions were monitored by TLC (silica gel, GF254) with UV light and $\mathrm{H}_{2} \mathrm{SO}_{4}$-anisaldehyde spray visualization. All tested compounds $(\mathbf{1} \mathbf{a} \sim \mathbf{1 j})$ were $\geq 95 \%$ pure by HPLC.

\section{2'-tert-butyldimethylsilyl-10-dehydro-10-deacetylpaclitaxel (4)}

To a solution of $3(788 \mathrm{mg}, 0.852 \mathrm{mmol})$ in methanol $(22.5 \mathrm{~mL})$ was added $\mathrm{Cu}(\mathrm{OAc})_{2} \mathrm{H}_{2} \mathrm{O}$ (848 mg, $\left.4.260 \mathrm{mmol}\right)$. The suspension was stirred at room temperature overnight (open air) and then diluted with ethyl acetate. The organic phase was washed sequentially with saturated aqueous $\mathrm{NaCl}, 2 \mathrm{~N} \mathrm{NH}_{3}$ to remove copper salts and saturated aqueous $\mathrm{NH}_{4} \mathrm{Cl}$. After drying $\left(\mathrm{Na}_{2} \mathrm{SO}_{4}\right)$ and evaporation under reduced pressure, the crude product was purified by silica gel chromatography (ethyl acetate $:$ petroleum ether $=3.8: 10)$ to give normal product $(7-\beta-\mathrm{OH})$ as a white solid (112 mg) and a mixture of epimers $(7-\alpha-\mathrm{OH}$ and $7-\beta-\mathrm{OH}, 618 \mathrm{mg}$, $92.8 \%$ total yield). ${ }^{1} \mathrm{H}$ NMR $\left(600 \mathrm{MHz}, \mathrm{CDCl}_{3}\right) \delta-0.30\left(\mathrm{~s}, 3 \mathrm{H} \mathrm{Si}\left(\mathrm{CH}_{3}\right)_{2}\right),-0.04(\mathrm{~s}, 3 \mathrm{H}$, $\left.\mathrm{Si}\left(\mathrm{CH}_{3}\right)_{2}\right), 0.79\left(\mathrm{~s}, 9 \mathrm{H}, \mathrm{SiC}\left(\mathrm{CH}_{3}\right)_{3}\right), 1.13\left(\mathrm{~s}, 3 \mathrm{H}, \mathrm{CH}_{3}\right), 1.21\left(\mathrm{~s}, 3 \mathrm{H}, \mathrm{CH}_{3}\right), 1.75(\mathrm{~s}, 3 \mathrm{H}$, $\mathrm{CH}_{3}$ ), $1.86\left(\mathrm{~s}, 3 \mathrm{H}, \mathrm{CH}_{3}\right.$ ), 2.18-2.21 (m, 1H, H-6b), 2.28-2.30 (overlap, 2H, H-14b, H-14a), 2.48 (dd, $J=15.6,9.6 \mathrm{~Hz}, 1 \mathrm{H}, \mathrm{H}-6 \mathrm{a}), 2.68$ (s, 3H, $\left.\mathrm{CH}_{3}\right), 3.87-3.89$ (m, 1H, 7-OH), 4.04 (d, $J=7.2 \mathrm{~Hz}, 1 \mathrm{H}, \mathrm{H}-3), 4.38$ (d, $J=9.0 \mathrm{~Hz}, 1 \mathrm{H}, \mathrm{H}-20 \mathrm{~b}), 4.44$ (d, $J=$ $8.4 \mathrm{~Hz}, 1 \mathrm{H}, \mathrm{H}-20 \mathrm{a}), 4.50$ (d, $J=11.4 \mathrm{~Hz}, 1 \mathrm{H}, \mathrm{H}-7), 4.67$ (d, $J=1.8 \mathrm{~Hz}, 1 \mathrm{H}, \mathrm{H}-2$ '), 4.92-4.94 (m, 1H, H-5), 5.79 (dd, $J=8.7,1.5 \mathrm{~Hz}, 1 \mathrm{H}, \mathrm{H}-3$ '), 5.87 (d, $J=7.2 \mathrm{~Hz}, 1 \mathrm{H}$, $\mathrm{H}-2), 6.28$ (t, $J=8.7 \mathrm{~Hz}, 1 \mathrm{H}, \mathrm{H}-13), 7.06$ (d, $J=9.0 \mathrm{~Hz}, 1 \mathrm{H}, \mathrm{NH}), 7.31-7.64(\mathrm{~m}, 11 \mathrm{H}$, Ar), 7.73 (d, $J=7.8 \mathrm{~Hz}, 2 \mathrm{H}, \mathrm{Ar}), 8.19$ (d, $J=7.8 \mathrm{~Hz}, 1 \mathrm{H}, \mathrm{Ar})$; MS (ESI) $m / z[\mathrm{M}+\mathrm{H}]^{+}$ 924.2.

\section{2'-tert-butyldimethylsilyl-10-dehydro-7-8-seco-10-deacetylpaclitaxel (5)}

L-selectride (1M solution in THF, $3.15 \mathrm{~mL}$ ) was added, dropwise to a solution of 4 (728 $\mathrm{mg}, 0.789 \mathrm{mmol})$ in THF $(10.0 \mathrm{~mL})$ at $-20^{\circ} \mathrm{C}$. After $8 \mathrm{~min}$, the reaction was quenched by addition of cold ethyl acetate $(20.0 \mathrm{~mL})$ and $2 \mathrm{~N} \mathrm{H}_{2} \mathrm{SO}_{4}(4.0 \mathrm{~mL})$. The reaction mixture was extracted with ethyl acetate and the combined organic phases were washed with saturated aqueous $\mathrm{NaHCO}_{3}$ and saturated aqueous $\mathrm{NH}_{4} \mathrm{Cl}$. The 
resulting solution was dried over anhydrous $\mathrm{MgSO}_{4}$ and the solvent evaporated under reduced pressure to give a crude product. The crude product was purified by silica gel chromatography (ethyl acetate : petroleum ether $=1: 2$ ) gave product 5 as a white solid (398 mg, 54.6\% yield): ${ }^{1} \mathrm{H}$ NMR (400 MHz, $\left.\mathrm{CDCl}_{3}\right) \delta-0.31\left(\mathrm{~s}, 3 \mathrm{H}, \mathrm{Si}\left(\mathrm{CH}_{3}\right)_{2}\right)$, -0.08 (s, 3H, $\left.\mathrm{Si}\left(\mathrm{CH}_{3}\right)_{2}\right), 0.78\left(\mathrm{~s}, 9 \mathrm{H}, \mathrm{SiC}\left(\mathrm{CH}_{3}\right)_{3}\right), 1.10\left(\mathrm{~s}, 3 \mathrm{H}, \mathrm{CH}_{3}\right), 1.27$ (s, 3H, $\left.\mathrm{CH}_{3}\right)$, $1.86\left(\mathrm{br}, 6 \mathrm{H}, 2 \times \mathrm{CH}_{3}\right), 1.91\left(\mathrm{~s}, 3 \mathrm{H}, \mathrm{CH}_{3}\right), 2.03-2.08(\mathrm{~m}, 1 \mathrm{H}, \mathrm{H}-6 \mathrm{~b}), 2.25$ (dd, $J=15.6$, 9.3Hz, 1H, H-14b), 2.69 (br, 1H, H-14a), 2.79 (br, 1H, H-6a), 3.79 (br, 1H, H-7b), 3.95 (br, 1H, H-7a), 4.21 (br, 1H, H- 20b), 4.30 (d, J = 7.8Hz, 1H, H-3), 4.71 (d, $J=$ 1.8Hz, 1H, H-2'), 5.24-5.30 (br, 2H, H-5, H-20a), 5.60 (d, J =9.6Hz, 1H, H-2), 5.91 (d, $J=9.0 \mathrm{~Hz}, 1 \mathrm{H}, \mathrm{H}-3$ '), 6.30 (t, $J=8.7 \mathrm{~Hz}, 1 \mathrm{H}, \mathrm{H}-13$ ), 6.43 (s, 1H, 9-OH), 7.29-7.59 (m, 11H, Ar), $7.66(\mathrm{~d}, J=7.8 \mathrm{~Hz}, 2 \mathrm{H}, \mathrm{Ar}), 8.09$ (d, $J=7.8 \mathrm{~Hz}, 2 \mathrm{H}, \mathrm{Ar})$; MS (ESI) $m / z$ $[\mathrm{M}+\mathrm{H}]^{+}$926.4, $[\mathrm{M}+\mathrm{Na}]^{+}$948.4.

\section{2'-tert-butyldimethylsilyl-9-0-allyl-10-dehydro-7-8-seco-10-deacetylpaclitaxel}

(6a)

To a mixture of 5 (148 $\mathrm{mg}, 0.16 \mathrm{mmol})$, potassium carbonate $(155 \mathrm{mg}, 1.12 \mathrm{mmol})$ and potassium iodide $(20 \mathrm{mg}, 0.121 \mathrm{mmol})$ in $\mathrm{DMF}(2.5 \mathrm{~mL})$ was added 3-bromoprop-1-ene $(97 \mu \mathrm{L} 1.12 \mathrm{mmol})$ dropwise at $0^{\circ} \mathrm{C}$. The reaction mixture was stirred for $3 \mathrm{~h}$ at room temperature and then diluted with ethyl acetate. The organic phase was washed with saturated aqueous $\mathrm{NH}_{4} \mathrm{Cl}$. The organic layer dried over anhydrous $\mathrm{Na}_{2} \mathrm{SO}_{4}$ and then concentrated under reduced pressure. Purification of the crude product by silica gel chromatography (ethyl acetate : petroleum ether $=7: 18$ ) gave product 6a as a white solid (118 mg, 76.4\% yield): ${ }^{1} \mathrm{H} \mathrm{NMR}\left(300 \mathrm{MHz}, \mathrm{CDCl}_{3}\right) \delta$ -0.33 (s, 3H, $\left.\mathrm{Si}\left(\mathrm{CH}_{3}\right)_{2}\right),-0.10$ (s, 3H, $\left.\mathrm{Si}\left(\mathrm{CH}_{3}\right)_{2}\right), 0.76$ (s, 9H, $\left.\mathrm{SiC}\left(\mathrm{CH}_{3}\right)_{3}\right), 1.18(\mathrm{~s}, 3 \mathrm{H}$, $\mathrm{CH}_{3}$ ), 1.27 (s, 3H, $\mathrm{CH}_{3}$ ), 1.81 (br, 3H, $\mathrm{CH}_{3}$ ), 1.88 (br, 3H, $\mathrm{CH}_{3}$ ), 1.94 (s, 3H, $\mathrm{CH}_{3}$ ), 2.14-2.32 (m, 2H, H-6b, H-14b), 2.75 (m, 2H, H-6a, H-14a), 3.76 (br, 1H, H-7b), 3.96 (br, 1H, H-7a), 4.20 (d, $J=8.4 \mathrm{~Hz}, 1 \mathrm{H}, \mathrm{H}-20 \mathrm{~b}$ ), 4.26-4.34 (overlap, 1H, 9-OCH $\mathrm{Cb}_{2}$ ), $4.27(\mathrm{~d}, J=7.5 \mathrm{~Hz}, 1 \mathrm{H}, \mathrm{H}-3), 4.47\left(\mathrm{dd}, J=11.9,6.2 \mathrm{~Hz}, 1 \mathrm{H}, 9-\mathrm{OCH}_{2 \mathrm{a}}\right), 4.70(\mathrm{~d}, J=$ 2.1Hz, 1H, H-2'), 5.20-5.32 (overlap, 2H, H-5, H-20a), 5.25 (d, $J=10.8 \mathrm{~Hz}, 1 \mathrm{H}$, 9- $\left.\mathrm{OCH}_{2} \mathrm{CH}=\mathrm{CH}_{2 \mathrm{~b}}\right), 5.35\left(\mathrm{~d}, J=17.1 \mathrm{~Hz}, 1 \mathrm{H}, 9-\mathrm{OCH}_{2} \mathrm{CH}=\mathrm{CH}_{2 \mathrm{a}}\right), 5.57(\mathrm{~d}, J=9.6 \mathrm{~Hz}$, 
1H, H-2), 5.90 (d, J = 9.0Hz, 1H, H-3'), 5.98-6.11 (m, 1H, 9- $\left.-\mathrm{OCH}_{2} \mathrm{CH}=\mathrm{CH}\right), 6.29$ (t, $J=8.6 \mathrm{~Hz}, 1 \mathrm{H}, \mathrm{H}-13), 7.29-7.58(\mathrm{~m}, 11 \mathrm{H}, \mathrm{Ar}), 7.63$ (d, $J=7.5 \mathrm{~Hz}, 2 \mathrm{H}, \mathrm{Ar}), 8.08$ (d, $J$ $=7.2 \mathrm{~Hz}, 2 \mathrm{H}, \mathrm{Ar}) ; \mathrm{MS}(\mathrm{ESI}) \mathrm{m} / \mathrm{z}[\mathrm{M}+\mathrm{H}]^{+}$966.3, $[\mathrm{M}+\mathrm{Na}]^{+}$988.3.

\section{2'-tert-butyldimethylsilyl-9-O-homoallyl-10-dehydro-7-8-seco-10-deacetyl paclitaxel (6b)}

The experimental procedure is the same as that prepared compound $\mathbf{6 a}$, but, the reaction time was prolonged to $4 \mathrm{~h}$. Yield of $60.2 \%$; white solid; ${ }^{1} \mathrm{H}$ NMR $(400 \mathrm{MHz}$, $\left.\mathrm{CDCl}_{3}\right) \delta-0.33\left(\mathrm{~s}, 3 \mathrm{H}, \mathrm{Si}\left(\mathrm{CH}_{3}\right)_{2}\right),-0.09\left(\mathrm{~s}, 3 \mathrm{H}, \mathrm{Si}\left(\mathrm{CH}_{3}\right)_{2}\right), 0.76\left(\mathrm{~s}, 9 \mathrm{H}, \mathrm{SiC}\left(\mathrm{CH}_{3}\right)_{3}\right)$, $1.19\left(\mathrm{~s}, 3 \mathrm{H}, \mathrm{CH}_{3}\right), 1.27$ (s, 3H, $\left.\mathrm{CH}_{3}\right), 1.81\left(\mathrm{br}, 3 \mathrm{H}, \mathrm{CH}_{3}\right), 1.87$ (br, $\left.3 \mathrm{H}, \mathrm{CH}_{3}\right), 1.96$ (s, $3 \mathrm{H}, \mathrm{CH}_{3}$ ), 1.99-2.07 (m, 2H, H-6b, OH), 2.21-2-27 (m, 1H, H-14b), 2.50 (dd, J=13.0, $6.6 \mathrm{~Hz}, 2 \mathrm{H}, \mathrm{OCH}_{2} \mathrm{CH}_{2}$ ), 2.65 (br, 1H, H-6a), 2.73 (m, 1H, H-14a), 3.76-3.81, 3.93-3.98 (m, 4H, H-7a, H-7b, 9-OCH $), 4.19$ (d, $J=6.8 \mathrm{~Hz}, 1 \mathrm{H}, \mathrm{H}-20 \mathrm{~b}), 4.27$ (d, $J=$ $7.6 \mathrm{~Hz}, 1 \mathrm{H}, \mathrm{H}-3), 4.69$ (s, 1H, H-2'), 5.10 (d, $\left.J=10.0 \mathrm{~Hz}, 1 \mathrm{H}, 9-\mathrm{OCH}_{2} \mathrm{CH}=\mathrm{CH}_{2 \mathrm{~b}}\right), 5.17$ (d, $J=17.2 \mathrm{~Hz}, 1 \mathrm{H}, 9-\mathrm{OCH}_{2} \mathrm{CH}=\mathrm{CH}_{2 \mathrm{a}}$ ), 5.20-5.28 (overlap, 2H, H-5, H-20a), 5.57 (d, $J=9.2 \mathrm{~Hz}, 1 \mathrm{H}, \mathrm{H}-2$ ), 5.85-5.91 (overlap, $\left.1 \mathrm{H}, 9-\mathrm{OCH}_{2} \mathrm{CH}=\mathrm{CH}\right), 5.90(\mathrm{~d}, J=8.0 \mathrm{~Hz}, 1 \mathrm{H}$, H-3'), 6.30 (t, $J=8.2 \mathrm{~Hz}, 1 \mathrm{H}, \mathrm{H}-13), 7.29-7.59$ (m, 11H, Ar), 7.63 (d, J=7.6Hz, 2H, Ar), $8.08(\mathrm{~d}, J=7.6 \mathrm{~Hz}, 2 \mathrm{H}, \mathrm{Ar})$; MS (ESI) $m / z[\mathrm{M}+\mathrm{H}]^{+} 980.3,[\mathrm{M}+\mathrm{Na}]^{+} 1002.3$.

\section{2'-tert-butyldimethylsilyl-9-O-(3-ethenyl)-propyl-10-dehydro-7-8-seco-10-}

\section{deacetylpaclitaxel (6c)}

Yield of 59.7\%; white solid; ${ }^{1} \mathrm{H}$ NMR $\left(400 \mathrm{MHz}, \mathrm{CDCl}_{3}\right) \delta-0.33$ (s, $\left.3 \mathrm{H}, \mathrm{Si}\left(\mathrm{CH}_{3}\right)_{2}\right)$, -0.09 (s, 3H, $\left.\mathrm{Si}\left(\mathrm{CH}_{3}\right)_{2}\right), 0.76$ (s, 9H, $\left.\mathrm{SiC}\left(\mathrm{CH}_{3}\right)_{3}\right), 1.19$ (s, 3H, $\left.\mathrm{CH}_{3}\right), 1.27$ (s, 3H, $\left.\mathrm{CH}_{3}\right)$, 1.80 2.27 (m, 13H, $\left.2 \times \mathrm{CH}_{3}, \mathrm{H}-6 \mathrm{~b}, \mathrm{H}-14 \mathrm{~b}, \mathrm{H}-6 \mathrm{a}, 9-\mathrm{OCH}_{2} \mathrm{CH}_{2} \mathrm{CH}_{2}\right), 1.96\left(\mathrm{~s}, 3 \mathrm{H}, \mathrm{CH}_{3}\right)$, 2.70 (m, 1H, H-14a), 3.71 3.77, 3.85 3.96 (m, 4H, 9-OCH $\left.\mathrm{Ob}_{2 \mathrm{~b}} \mathrm{H}-7 \mathrm{~b}, 9-\mathrm{OCH}_{2 \mathrm{a}}, \mathrm{H}-7 \mathrm{a}\right)$, $4.17 \sim 4.20$ (m, 1H, H-20b), 4.27 (d, $J=8.0 \mathrm{~Hz}, 1 \mathrm{H}, \mathrm{H}-3), 4.69(\mathrm{~d}, J=2.0 \mathrm{~Hz}, 1 \mathrm{H}$, H-2'), 4.99 5.09 (m, 2H, 9-O $\left.\left(\mathrm{CH}_{2}\right)_{3} \mathrm{CH}=\mathrm{CH}_{2}\right)$, 5.26-5.28 (m, 2H, H-5, H-20a), 5.57 (d, $J=9.6 \mathrm{~Hz}, 1 \mathrm{H}, \mathrm{H}-2), 5.80-5.87\left(\mathrm{~m}, 1 \mathrm{H}, 9-\mathrm{OCH}_{2} \mathrm{CH}=\mathrm{CH}\right), 5.91(\mathrm{~d}, J=8.0 \mathrm{~Hz}, 1 \mathrm{H}$, H-3'), 6.30 (t, $J=8.8 \mathrm{~Hz}, 1 \mathrm{H}, \mathrm{H}-13), 7.28-7.59$ (m, 11H, Ar), 7.63 (d, $J=7.6 \mathrm{~Hz}, 2 \mathrm{H}$, $\operatorname{Ar}), 8.09(\mathrm{~d}, J=7.2 \mathrm{~Hz}, 2 \mathrm{H}, \mathrm{Ar})$; MS (ESI) $\mathrm{m} / \mathrm{z}[\mathrm{M}+\mathrm{H}]^{+}$994.4, $[\mathrm{M}+\mathrm{Na}]^{+} 1016.4$. 


\section{2'-tert-butyldimethylsilyl-7,9-O-bis(allyl)-10-dehydro-7-8-seco-10-deacetyl}

paclitaxel (7a)

Trifluoromethanesulfonic anhydride (134 $\mu \mathrm{L}, 0.793 \mathrm{mmol})$ was added to dry dichloromethane $(1.3 \mathrm{~mL})$ at $-55^{\circ} \mathrm{C}$. A solution of prop-2-en-1-ol $(60 \mu \mathrm{L}, 0.878 \mathrm{mmol})$ and 2,6-di-tert-butyl-4-methylpyridine $(156 \mu \mathrm{L}, 1.12 \mathrm{mmol})$ in dichloromethane $(1.0$ $\mathrm{mL}$ ) was added dropwise. The reaction was stirred at $-40{ }^{\circ} \mathrm{C}$ for $25 \mathrm{~min}$ and the reaction solution was maintained at $-50{ }^{\circ} \mathrm{C}$. To a solution of $\mathbf{6 a}(84 \mathrm{mg}, 0.0870 \mathrm{mmol})$ and 2,6-di-tert-butyl-4-methylpyridine $(91 \mu \mathrm{L}, 0.653 \mathrm{mmol})$ in dichloromethane (1.3 $\mathrm{mL})$ was added a solution of allyl trifluoromethanesulfonate $(1.2 \mathrm{~mL})$ in dichloromethane prepared above, the reaction mixture was stirred for $1 \mathrm{~h} 20 \mathrm{~min}$ between $-38{ }^{\circ} \mathrm{C}$ and $-49{ }^{\circ} \mathrm{C}$ and then another portion of allyl trifluoromethanesulfonate solution $(0.3 \mathrm{~mL})$ and 2,6-di-tert-butyl-4-methylpyridine (40 $\mu \mathrm{L}, 0.288 \mathrm{mmol})$ was added again. The reaction mixture was stirred for $35 \mathrm{~min}$ at the same temperature and then diluted with ethyl acetate $(30 \mathrm{~mL})$. The mixture was washed with saturated aqueous $\mathrm{Na}_{2} \mathrm{CO}_{3}(10 \mathrm{~mL})$ and saturated aqueous $\mathrm{NH}_{4} \mathrm{Cl}(2 \times 10 \mathrm{~mL})$. The organic layer dried over anhydrous $\mathrm{Na}_{2} \mathrm{SO}_{4}$ and then concentrated under reduced pressure. Purification of the crude product by silica gel chromatography (ethyl acetate : petroleum ether $=2: 7$ ) gave product $7 \mathbf{a}$ as a white solid (26 mg, 29.7\% yield) and recovered start material $(18 \mathrm{mg}):{ }^{1} \mathrm{H}$ NMR $\left(300 \mathrm{MHz}, \mathrm{CDCl}_{3}\right) \delta-0.27(\mathrm{~s}, 3 \mathrm{H}$, $\left.\mathrm{Si}\left(\mathrm{CH}_{3}\right)_{2}\right),-0.05\left(\mathrm{~s}, 3 \mathrm{H}, \mathrm{Si}\left(\mathrm{CH}_{3}\right)_{2}\right), 0.81$ (s, 9H, $\left.\mathrm{SiC}\left(\mathrm{CH}_{3}\right)_{3}\right), 1.20\left(\mathrm{~s}, 3 \mathrm{H}, \mathrm{CH}_{3}\right), 1.22$ (s, $3 \mathrm{H}, \mathrm{CH}_{3}$ ), 1.94-2.10 (overlap, 6H, $\left.2 \times \mathrm{CH}_{3}\right), 1.88\left(\mathrm{~s}, 3 \mathrm{H}, \mathrm{CH}_{3}\right), 2.17-2.32(\mathrm{~m}, 2 \mathrm{H}$, H-6b, H-14b), 2.66 (br, 1H, H-6a), 2.79 (br, 1H, H-14a), 3.58 (br, 2H, H-7a, H-7b), $3.87\left(\mathrm{~d}, J=5.7 \mathrm{~Hz}, 2 \mathrm{H}, 7-\mathrm{OCH}_{2}\right), 4.27-4.36$ (m, 3H, H-3, H-20b, 9-OCH $\mathrm{Ob}_{2 \mathrm{~b}}$ ), 4.48 (dd, $J=8.4,6.0 \mathrm{~Hz}, 1 \mathrm{H}, 9-\mathrm{OCH}_{2 \mathrm{a}}$ ), 4.67 (s, 1H, H-2'), 5.07-5.27 (overlap, 2H, H-5, H-20a), $5.09\left(\mathrm{~d}, J=10.5 \mathrm{~Hz}, 1 \mathrm{H}, 7-\mathrm{OCH}_{2} \mathrm{CH}=\mathrm{CH}_{2 \mathrm{~b}}\right), \quad 5.17(\mathrm{~d}, J=17.4 \mathrm{~Hz}, 1 \mathrm{H}$, $\left.7-\mathrm{OCH}_{2} \mathrm{CH}=\mathrm{CH}_{2 \mathrm{a}}\right), 5.25\left(\mathrm{~d}, J=10.2 \mathrm{~Hz}, 1 \mathrm{H}, 9-\mathrm{OCH}_{2} \mathrm{CH}=\mathrm{CH}_{2 \mathrm{~b}}\right), 5.36(\mathrm{~d}, J=17.1 \mathrm{~Hz}$, $\left.1 \mathrm{H}, 9-\mathrm{OCH}_{2} \mathrm{CH}=\mathrm{CH}_{2 \mathrm{a}}\right), 5.62(\mathrm{~d}, J=9.3 \mathrm{~Hz}, 1 \mathrm{H}, \mathrm{H}-2), 5.75(\mathrm{~d}, J=8.7,1.2 \mathrm{~Hz}, 1 \mathrm{H}$, H-3'), 5.77-5.88 (m, 1H, 7- $\left.\mathrm{OCH}_{2} \mathrm{CH}=\mathrm{CH}\right), 5.99-6.13$ (m, 1H, 9- $\left.\mathrm{OCH}_{2} \mathrm{CH}=\mathrm{CH}\right), 6.21$ (t, $J=8.3 \mathrm{~Hz}, 1 \mathrm{H}, \mathrm{H}-13), 7.10(\mathrm{~d}, J=9.3 \mathrm{~Hz}, 1 \mathrm{H}, \mathrm{NH}), 7.26-7.62(\mathrm{~m}, 11 \mathrm{H}, \mathrm{Ar}), 7.72(\mathrm{~d}$, 
$J=6.9 \mathrm{~Hz}, 2 \mathrm{H}, \mathrm{Ar}), 8.15(\mathrm{~d}, J=7.2 \mathrm{~Hz}, 2 \mathrm{H}, \mathrm{Ar}) ; \mathrm{MS}(\mathrm{ESI}) \mathrm{m} / \mathrm{z}[\mathrm{M}+\mathrm{H}]^{+} 1006.6,[\mathrm{M}+$ $\mathrm{Na}]^{+} 1028.5$.

\section{2'-tert-butyldimethylsilyl-7-O-allyl-9-O-homoallyl-10-dehydro-7-8-seco-10-} deacetyl paclitaxel (7b)

Yield of 38.2\%; white solid; ${ }^{1} \mathrm{H}$ NMR (400 $\left.\mathrm{MHz}, \mathrm{CDCl}_{3}\right) \delta-0.33\left(\mathrm{~s}, 3 \mathrm{H}, \mathrm{Si}\left(\mathrm{CH}_{3}\right)_{2}\right)$, -0.05 (s, 3H, $\left.\mathrm{Si}\left(\mathrm{CH}_{3}\right)_{2}\right), 0.80\left(\mathrm{~s}, 9 \mathrm{H}, \mathrm{SiC}\left(\mathrm{CH}_{3}\right)_{3}\right), 1.20\left(\mathrm{~s}, 3 \mathrm{H}, \mathrm{CH}_{3}\right), 1.22\left(\mathrm{~s}, 3 \mathrm{H}, \mathrm{CH}_{3}\right)$, 1.73-2.17 (overlap, 7H, $2 \times \mathrm{CH}_{3}, \mathrm{H}-6 \mathrm{~b}$ ), $1.88\left(\mathrm{~s}, 3 \mathrm{H}, \mathrm{CH}_{3}\right), 2.25-2.31$ (m, 1H, H-14b), 2.50 (m, 2H, $\mathrm{OCH}_{2} \mathrm{CH}_{2}$ ), 2.66 (br, 1H, H-6a), 2.80 (br, 1H, H-14a), 3.58 (br, 2H, H-7a, $\mathrm{H}-7 \mathrm{~b}), 3.87$ (d, $J=4.8 \mathrm{~Hz}, 2 \mathrm{H}, 7-\mathrm{OCH}_{2}$ ), 3.77-3.83 (m, 1H, 9-OCH $\mathrm{Ob}_{2}$ ), 3.93-3.99 (m, 1H, 9-OCH $\mathrm{Oa}_{\mathrm{a}}$ ), 4.27-4.34 (m, 2H, H-3, H-20b), 4.68 (s, 1H, H-2'), 5.08-5.19 (m, 4H, 7- $\mathrm{OCH}_{2} \mathrm{CH}=\mathrm{CH}_{2}, 9-\mathrm{O}\left(\mathrm{CH}_{2}\right)_{2} \mathrm{CH}=\mathrm{CH}_{2}$ ), 5.08-5.25 (overlap, $2 \mathrm{H}, \mathrm{H}-5+\mathrm{H}-20 \mathrm{a}$ ), 5.61 $(\mathrm{d}, J=9.2 \mathrm{~Hz}, 1 \mathrm{H}, \mathrm{H}-2), 5.75(\mathrm{~d}, J=8.8 \mathrm{~Hz}, 1 \mathrm{H}, \mathrm{H}-3$ ') $5.79-5.92(\mathrm{~m}, 2 \mathrm{H}$, 7- $\left.\mathrm{OCH}_{2} \mathrm{CH}=\mathrm{CH}_{2}, 9-\mathrm{O}\left(\mathrm{CH}_{2}\right)_{2} \mathrm{CH}=\mathrm{CH}\right), 6.21(\mathrm{t}, J=8.0 \mathrm{~Hz}, 1 \mathrm{H}, \mathrm{H}-13), 7.10(\mathrm{~d}, J=$ $8.8 \mathrm{~Hz}, 1 \mathrm{H}, \mathrm{NH}), 7.30-7.61(\mathrm{~m}, 11 \mathrm{H}, \mathrm{Ar}), 7.72(\mathrm{~d}, J=7.6 \mathrm{~Hz}, 2 \mathrm{H}, \mathrm{Ar}), 8.14$ (d, $J=$ 7.2Hz, $2 \mathrm{H}, \mathrm{Ar}$ ); HRMS (ESI, $\left[\mathrm{M}+\mathrm{Na}^{+}\right]$) m/z calcd for $\mathrm{C}_{58} \mathrm{H}_{73} \mathrm{NO}_{13} \mathrm{Si} \mathrm{Na}$ : 1042.4749; Found: 1042.4753 .

\section{2'-tert-butyldimethylsilyl-7-O-allyl-9-O-(3-ethenyl)-propyl-10-dehydro-7-8-seco-}

\section{0- deacetyl paclitaxel (7c)}

Yield of 27.7\%; white solid; ${ }^{1} \mathrm{H}$ NMR (400 MHz, $\left.\mathrm{CDCl}_{3}\right) \delta-0.28\left(\mathrm{~s}, 3 \mathrm{H}, \mathrm{Si}\left(\mathrm{CH}_{3}\right)_{2}\right)$, -0.05 (s, 3H, $\left.\mathrm{Si}\left(\mathrm{CH}_{3}\right)_{2}\right), 0.80\left(\mathrm{~s}, 9 \mathrm{H}, \mathrm{SiC}\left(\mathrm{CH}_{3}\right)_{3}\right), 1.20\left(\mathrm{~s}, 3 \mathrm{H}, \mathrm{CH}_{3}\right), 1.22\left(\mathrm{~s}, 3 \mathrm{H}, \mathrm{CH}_{3}\right)$, 1.82-2.31 (m, $\left.12 \mathrm{H}, 2 \times \mathrm{CH}_{3}, \mathrm{H}-6 \mathrm{~b}, \mathrm{H}-14 \mathrm{~b}, 9-\mathrm{OCH}_{2} \mathrm{CH}_{2} \mathrm{CH}_{2}\right), 1.88\left(\mathrm{~s}, 3 \mathrm{H}, \mathrm{CH}_{3}\right)$, 2.66-2.80 (m, 2H, H-6a, H-14a), 3.58 (br, 2H, H-7a, H-7b), 3.73-3.93 (m, 4H, 9- $\left.\mathrm{OCH}_{2}, 7-\mathrm{OCH}_{2}\right), 4.28$ (d, $\left.J=8.0 \mathrm{~Hz}, 1 \mathrm{H}, \mathrm{H}-3\right), 4.36$ (br, 1H, H-20b), 4.67 (s, 1H, H-2'), 4.98-5.19 (m, 5H, 7- $\mathrm{OCH}_{2} \mathrm{CH}=\mathrm{CH}_{2}, 9-\mathrm{O}\left(\mathrm{CH}_{2}\right)_{3} \mathrm{CH}=\mathrm{CH}_{2}, \mathrm{H}-5$ ), 5.26 (overlap, 1H, H-20a), 5.61 (d, $J=9.2 \mathrm{~Hz}, 1 \mathrm{H}, \mathrm{H}-2), 5.75$ (d, $J=8.8 \mathrm{~Hz}, 1 \mathrm{H}, \mathrm{H}-3$ '), $5.76-5.88$ (m, $\left.2 \mathrm{H}, 7-\mathrm{OCH}_{2} \mathrm{CH}=\mathrm{CH}, 9-\mathrm{O}\left(\mathrm{CH}_{2}\right)_{3} \mathrm{CH}=\mathrm{CH}\right), 6.21(\mathrm{t}, J=8.4 \mathrm{~Hz}, 1 \mathrm{H}, \mathrm{H}-13), 7.08(\mathrm{~d}, J=$ $\left.8.8 \mathrm{~Hz}, 1 \mathrm{H}, 3^{\prime}-\mathrm{NH}\right), 7.29-7.62$ (m, 11H, Ar), 7.72 (d, $\left.J=8.0 \mathrm{~Hz}, 2 \mathrm{H}, \mathrm{Ar}\right), 8.14$ (d, $J=$ 7.2Hz, $2 \mathrm{H}, \mathrm{Ar}$ ); HRMS (ESI, $\left[\mathrm{M}+\mathrm{Na}^{+}\right]$) m/z calcd for $\mathrm{C}_{59} \mathrm{H}_{75} \mathrm{NO}_{13} \mathrm{Si} \mathrm{Na}: 1056.4905$; Found: 1056.4902. 


\section{Macrocyclic Taxoid (8a)}

To a solution of $7 \mathbf{a}(18 \mathrm{mg}, 0.0179 \mathrm{mmol})$ in 1,2-dichloroethane $(7.0 \mathrm{~mL})$ was added Grubbs second generation catalyst $(3.0 \mathrm{mg}, 0.00353 \mathrm{mmol})$. The reaction was stirred for $3 \mathrm{~h} 30 \mathrm{~min}$ at $42{ }^{\circ} \mathrm{C}$ and then another portion of catalyst $(1.5 \mathrm{mg}, 0.00177 \mathrm{mmol})$ was added and the reaction was stirred for $12 \mathrm{~h}$ at the same temperature. The solvent was removed by reduced pressure. The residue was purified by silica gel chromatography (ethyl acetate : petroleum ether $=2: 7$ ) to give product 8a as a light yellow solid (8 mg, 45.7\% yield): ${ }^{1} \mathrm{H}$ NMR (500 MHz, Acetone- $\left.d_{6}\right) \delta-0.16\left(\mathrm{~s}, 3 \mathrm{H}, \mathrm{Si}\left(\mathrm{CH}_{3}\right)_{2}\right),-0.01$ (s, 3H, $\left.\mathrm{Si}\left(\mathrm{CH}_{3}\right)_{2}\right), 0.81\left(\mathrm{~s}, 9 \mathrm{H}, \mathrm{SiC}\left(\mathrm{CH}_{3}\right)_{3}\right), 1.17\left(\mathrm{~s}, 3 \mathrm{H}, \mathrm{CH}_{3}\right), 1.19\left(\mathrm{~s}, 3 \mathrm{H}, \mathrm{CH}_{3}\right), 1.76$ (d, $J=1.0 \mathrm{~Hz}, 3 \mathrm{H}, \mathrm{CH}_{3}$ ), 1.92-1.97 (m, 1H, H-6b), 2.24 (dd, $\left.J=15.3,8.8 \mathrm{~Hz}, 1 \mathrm{H}, \mathrm{H}-14 \mathrm{~b}\right)$, $2.50\left(\mathrm{~s}, 3 \mathrm{H}, \mathrm{CH}_{3}\right), 2.56\left(\mathrm{~s}, 3 \mathrm{H}, \mathrm{CH}_{3}\right), 2.46$ (dd, $\left.J=15.3,9.0 \mathrm{~Hz}, 1 \mathrm{H}, \mathrm{H}-14 \mathrm{a}\right), 2.83-2.88$ (m, 1H, H-6a), 3.47 (m, 2H, H-7a, H-7b), $3.84(\mathrm{dd}, J=14.0,8.5 \mathrm{~Hz}, 1 \mathrm{H}$, $\left.7-\mathrm{OCH}_{2 \mathrm{~b}} \mathrm{CH}=\mathrm{CH}\right), 4.14\left(\mathrm{~d}, J=14.0 \mathrm{~Hz}, 1 \mathrm{H}, 7-\mathrm{OCH}_{2 \mathrm{a}} \mathrm{CH}=\mathrm{CH}\right), 4.20(\mathrm{~d}, J=8.0 \mathrm{~Hz}$, $1 \mathrm{H}, \mathrm{H}-20 \mathrm{~b}), 4.31$ (s, 1H, 1-OH), 4.41 (d, $J=8.0 \mathrm{~Hz}, 1 \mathrm{H}, \mathrm{H}-20 \mathrm{a}), 4.56$ (dd, $J=12.5$, $\left.4.0 \mathrm{~Hz}, 1 \mathrm{H}, 9-\mathrm{OCH}_{2 \mathrm{~b}} \cdot \mathrm{CH}=\mathrm{CH}\right), 4.67\left(\mathrm{dd}, J=10.3 \mathrm{~Hz}, 4.3 \mathrm{~Hz}, 1 \mathrm{H}, 9-\mathrm{OCH}_{2 \mathrm{a}} \mathrm{CH}=\mathrm{CH}\right)$, $4.73(\mathrm{~d}, J=7.5 \mathrm{~Hz}, 1 \mathrm{H}, \mathrm{H}-3), 4.90$ (d, $J=4.0 \mathrm{~Hz}, 1 \mathrm{H}, \mathrm{H}-2$ '), 5.24 (dd, $J=12.1,10.6 \mathrm{~Hz}$, 1H, H-5), 5.55 (d, $J=7.5 \mathrm{~Hz}, 1 \mathrm{H}, \mathrm{H}-2), 5.91$ (dd, $J=9.5 \mathrm{~Hz}, 4.0 \mathrm{~Hz}, 1 \mathrm{H}, \mathrm{H}-3$ '), 5.96 $(\mathrm{ddd}, J=15.5,8.5,3.5 \mathrm{~Hz}, 1 \mathrm{H}, \mathrm{CH}=\mathrm{CH}), 6.08(\mathrm{ddd}, J=15.4,10.6,3.5 \mathrm{~Hz}, 1 \mathrm{H}$, $\mathrm{CH}=\mathrm{CH}), 6.17(\mathrm{t}, J=8.5 \mathrm{~Hz}, 1 \mathrm{H}, \mathrm{H}-13), 7.31-7.67(\mathrm{~m}, 11 \mathrm{H}, \mathrm{Ar}), 7.82(\mathrm{dd}, J=7.8$, $1.5 \mathrm{~Hz}, 2 \mathrm{H}, \mathrm{Ar}), 7.93(\mathrm{~d}, J=9.5 \mathrm{~Hz}, 1 \mathrm{H}, \mathrm{NH}), 8.18(\mathrm{dd}, J=7.8,1.5 \mathrm{~Hz}, 1 \mathrm{H}, \mathrm{Ar}) ;{ }^{13} \mathrm{C}$ NMR $\left(150 \mathrm{MHz}, \mathrm{CDCl}_{3}\right) \delta-5.9,-5.2,13.7,14.7,18.1,21.6,23.0,25.5,26.2,33.5$, $36.3,42.4,42.8,55.6,69.3,70.8,71.7,73.7,75.1,75.3,76.5,78.5,84.5,90.8,126.3$, $127.0,127.9,128.7,128.8,129.1,129.6,130.2,131.8,133.7,134.1,137.8,138.1$, $138.4,138.3,139.2,144.9,149.9,166.8,167.0,169.2,171.1,194.0 ;$ MS (ESI) $m / z$ [M $+\mathrm{H}]^{+}$978.4, $[\mathrm{M}+\mathrm{Na}]^{+} 1000.4$.

\section{2'-tert-butyldimethylsilyl-Macrocyclic Taxoid (8b)}

To a solution of $7 \mathbf{b}(20 \mathrm{mg}, 0.0196 \mathrm{mmol})$ in 1,2-dichloroethane $(9.8 \mathrm{~mL})$ was added Grubbs second generation catalyst $(6.0 \mathrm{mg}, 0.00707 \mathrm{mmol})$. The reaction was stirred 
for $4 \mathrm{~h}$ at $55{ }^{\circ} \mathrm{C}$. The solvent was removed by reduced pressure. The residue was purified by silica gel preparative TLC (ethyl acetate : dichloromethane $=1: 12$ ) to afford product $\mathbf{8 b}$ as a white solid (4 $\mathrm{mg}$ ) and another trans isomer $\mathbf{8 g}(0.8 \mathrm{mg})$, the total yield is $24.7 \%$ : ${ }^{1} \mathrm{H}$ NMR (400 MHz, Acetone- $\left.d_{6}\right) \delta-0.16\left(\mathrm{~s}, 3 \mathrm{H}, \mathrm{Si}\left(\mathrm{CH}_{3}\right)_{2}\right), 0.02$ (s, 3H, $\left.\mathrm{Si}\left(\mathrm{CH}_{3}\right)_{2}\right), 0.81\left(\mathrm{~s}, 9 \mathrm{H}, \mathrm{SiC}\left(\mathrm{CH}_{3}\right)_{3}\right), 1.15$ (s, 3H, $\left.\mathrm{CH}_{3}\right), 1.19$ (s, 3H, $\left.\mathrm{CH}_{3}\right), 1.73$ (s, 3H, $\mathrm{CH}_{3}$ ), 1.99 (m, 1H, H-6b), 2.25-2.60 (overlap, 5H, H-14b, H-14a, H-6a, $\left.\mathrm{OCH}_{2} \mathrm{CH}_{2}\right), 2.45\left(\mathrm{~s}, 3 \mathrm{H}, \mathrm{CH}_{3}\right), 2.60\left(\mathrm{~s}, 3 \mathrm{H}, \mathrm{CH}_{3}\right), 3.36(\mathrm{~m}, 1 \mathrm{H}, \mathrm{H}-7 \mathrm{a}), 3.57(\mathrm{~m}, 1 \mathrm{H}$, wdH-7b), $3.72\left(\mathrm{dd}, J=14.0,7.2 \mathrm{~Hz}, 1 \mathrm{H}, \mathrm{OCH}_{2 \mathrm{~b}}\right), 4.12\left(\mathrm{~m}, 1 \mathrm{H}, \mathrm{OCH}_{2 \mathrm{a}}\right), 4.18-4.25(\mathrm{~m}$, $3 \mathrm{H}, \mathrm{H}-20 \mathrm{~b}, 1-\mathrm{OH}, \mathrm{OCH}_{2 \mathrm{~b}}$ ), 4.41 (d, $\left.J=7.6 \mathrm{~Hz}, 1 \mathrm{H}, \mathrm{H}-20 \mathrm{a}\right), 4.58-4.64$ (m, 2H, H-5, $\mathrm{OCH}_{2 \mathrm{a}}$ ), 4.79 (d, $\left.J=8.0 \mathrm{~Hz}, 1 \mathrm{H}, \mathrm{H}-3\right), 4.94$ (d, $J=4.0 \mathrm{~Hz}, 1 \mathrm{H}, \mathrm{H}-2$ '), 5.61 (d, $J=$ $8.0 \mathrm{~Hz}, 1 \mathrm{H}, \mathrm{H}-2$ ), 5.92 (dd, $J=9.2,4.0 \mathrm{~Hz}, 1 \mathrm{H}, \mathrm{H}-3$ '), 5.71 (ddd, $J=15.6,6.8,4.4 \mathrm{~Hz}$, $1 \mathrm{H}, \mathrm{CH}=\mathrm{CH}), 5.96($ overlap, $1 \mathrm{H}, \mathrm{CH}=\mathrm{CH}), 6.17(\mathrm{t}, J=8.8 \mathrm{~Hz}, 1 \mathrm{H}, \mathrm{H}-13), 7.29-7.68$ (m, 11H, Ar), 7.82 (d, $J=7.6 \mathrm{~Hz}, 2 \mathrm{H}, \mathrm{Ar}), 7.93(\mathrm{~d}, J=9.2 \mathrm{~Hz}, 1 \mathrm{H}, \mathrm{NH}), 8.20$ (d, $J=$ 7.2Hz, 1H, Ar). ${ }^{13} \mathrm{C} \mathrm{NMR}\left(150 \mathrm{MHz}, \mathrm{CDCl}_{3}\right):-5.91,-5.28,13.8 .14 .3,18.1,21.2,22.9$, $25.5,26,1,30.9,32,6,33.0,36.3,42.8,55.6,60.4,70.7,70.8,73.1,75.2,75.8,76.2$, $78.8,85.1,91.4,126.4,127.0,127.9,128.70,128.73,128.8,129.2,130.2,131.0$, 131.8, 132.0, 133.7, 134.1, 134.2, 138.0, 138.4, 144.6, 151.9, 166.90, 166.98, 169.3, 171.0, 192.5; HRMS (ESI, $\left[\mathrm{M}+\mathrm{Na}^{+}\right]$) $\mathrm{m} / \mathrm{z}$ calcd for $\mathrm{C}_{56} \mathrm{H}_{69} \mathrm{NO}_{13} \mathrm{Si} \mathrm{Na}$ : 1014.4436; Found: 1014.4447. Trans isomer ( $8 \mathrm{~g}$ ): ${ }^{1} \mathrm{H}$ NMR (500 MHz, $\left.\mathrm{CDCl}_{3}\right) \delta-0.31(\mathrm{~s}, 3 \mathrm{H}$, $\left.\mathrm{Si}\left(\mathrm{CH}_{3}\right)_{2}\right),-0.04$ (s, 3H, $\left.\mathrm{Si}\left(\mathrm{CH}_{3}\right)_{2}\right), 0.79$ (s, 9H, $\left.\mathrm{SiC}\left(\mathrm{CH}_{3}\right)_{3}\right), 1.18\left(\mathrm{~s}, 3 \mathrm{H}, \mathrm{CH}_{3}\right), 1.24$ (s, $\left.3 \mathrm{H}, \mathrm{CH}_{3}\right), 1.84\left(\mathrm{~s}, 3 \mathrm{H}, \mathrm{CH}_{3}\right), 2.15-2.28,2.36-2.42,2.63-2.72$ (m, 6H, H-6b, H-14b, H-14a, H-6a, $\mathrm{OCH}_{2} \mathrm{CH}_{2}$ ), 2.53 (s, 3H, $\mathrm{CH}_{3}$ ), 2.60 (s, 3H, $\mathrm{CH}_{3}$ ), 3.42-3.51, 3.89-4.00 (m, 5H, H-7a, H-7b, OCH ${ }_{2 \mathrm{~b}}, \mathrm{OCH}_{2 \mathrm{a}}, \mathrm{OCH}_{2 \mathrm{~b}}$ ), 4.15 (m, 1H, OCH $\mathrm{Oa}_{\mathrm{a}}$ ), 3.36, 4.49 (d, J $=8.0 \mathrm{~Hz}, 2 \mathrm{H}, \mathrm{H}-20 \mathrm{~b}, \mathrm{H}-20 \mathrm{a}), 4.67$ (d, $J=1.5 \mathrm{~Hz}, 1 \mathrm{H}, \mathrm{H}-2$ '), 4.69 (dd, $J=10.5,3.0 \mathrm{~Hz}$, $1 \mathrm{H}, \mathrm{H}-5), 4.84$ (d, $J=8.0 \mathrm{~Hz}, 1 \mathrm{H}, \mathrm{H}-3), 5.60(\mathrm{~d}, J=7.5 \mathrm{~Hz}, 1 \mathrm{H}, \mathrm{H}-2), 5.71(\mathrm{dt}, J=$ $10.5,8.0 \mathrm{~Hz}, 1 \mathrm{H}, \mathrm{CH}=\mathrm{CH}), 5.76-5.80(\mathrm{~m}, 2 \mathrm{H}, \mathrm{CH}=\mathrm{CH}, \mathrm{H}-3$ '), $6.28(\mathrm{t}, J=9.0 \mathrm{~Hz}, 1 \mathrm{H}$, H-13), 7.09 (d, $\left.J=9.0 \mathrm{~Hz}, 1 \mathrm{H}, 3^{\prime}-\mathrm{NH}\right), 7.29-7.64$ (m, 11H, Ar), 7.76 (d, $J=8.0 \mathrm{~Hz}, 2 \mathrm{H}$, $\mathrm{Ar}), 8.18$ (d, $J=8.0 \mathrm{~Hz}, 1 \mathrm{H}, \mathrm{Ar}) ;{ }^{13} \mathrm{C} \mathrm{NMR}\left(125 \mathrm{MHz}, \mathrm{CDCl}_{3}\right):-5.67,-5.01,14.6 .14 .8$, 18.4, 22.1, 23.1, 25.7, 26.5, 29.6, 32,3, 36.8, 42.9, 43.1, 55.8, 63.2, 65.4, 70.6, 72.5, $75.5,75.6,76.5,78.9,84.8,90.5,126.6,127.2,128.1,128.95,129.02,129.05,129.4$, 
$130.37,130.44,132.1,134.0,134.4,136.9,138.6,139.6,144.9,152.6,167.1,167.2$, 169.8, 171.2, 192.3; HRMS (ESI, $\left[\mathrm{M}+\mathrm{Na}^{+}\right]$) $\mathrm{m} / \mathrm{z}$ calcd for $\mathrm{C}_{56} \mathrm{H}_{69} \mathrm{NO}_{13} \mathrm{Si} \mathrm{Na}$ : 1014.4436; Found: 1014.4438.

\section{2'- tert-butyldimethylsilyl-Macrocyclic Taxoid (8c)}

To a solution of $7 \mathbf{c}(38 \mathrm{mg}, 0.0368 \mathrm{mmol})$ in 1,2-dichloroethane $(9.0 \mathrm{~mL})$ was added Grubbs second generation catalyst $(8.5 \mathrm{mg}, 0.0100 \mathrm{mmol})$. The reaction was stirred for $4 \mathrm{~h}$ at $44^{\circ} \mathrm{C}$. The solvent was removed by reduced pressure. The residue was purified by silica gel preparative TLC (ethyl acetate : dichloromethane $=1: 10$ ) to afford product $8 \mathrm{c}$ as a white solid (15 mg, 40.6\% yield): ${ }^{1} \mathrm{H}$ NMR (500 MHz, Acetone- $\left.d_{6}\right) \delta-0.16\left(\mathrm{~s}, 3 \mathrm{H}, \mathrm{Si}\left(\mathrm{CH}_{3}\right)_{2}\right), 0.02\left(\mathrm{~s}, 3 \mathrm{H}, \mathrm{Si}\left(\mathrm{CH}_{3}\right)_{2}\right), 0.81\left(\mathrm{~s}, 9 \mathrm{H}, \mathrm{SiC}\left(\mathrm{CH}_{3}\right)_{3}\right)$, $1.18\left(\mathrm{~s}, 3 \mathrm{H}, \mathrm{CH}_{3}\right), 1.20\left(\mathrm{~s}, 3 \mathrm{H}, \mathrm{CH}_{3}\right), 1.73\left(\mathrm{~s}, 3 \mathrm{H}, \mathrm{CH}_{3}\right), 1.82-1.88(\mathrm{~m}, 1 \mathrm{H}, \mathrm{H}-6 \mathrm{~b})$, 1.92-2.00 (m, 2H, H-14a, H-14b), 2.25-2.41, 2.48-2.53 (m, 5H, $\left.\mathrm{OCH}_{2} \mathrm{CH}_{2} \mathrm{CH}_{2}, \mathrm{H}-6 \mathrm{a}\right)$, $2.56\left(\mathrm{~s}, 3 \mathrm{H}, \mathrm{CH}_{3}\right), 2.59$ (s, 3H, $\left.\mathrm{CH}_{3}\right), 3.39-3.45$ (m, 1H, H-7b), 3.49-3.55 (m, 1H, H-7a), 3.76-3.81 (m, 1H, OCH ${ }_{2 b}$ ), 3.84 (dd, $J=13.3,5.8 \mathrm{~Hz}, 1 \mathrm{H}, \mathrm{OCH}_{2 \mathrm{~b}}$ ), 3.97 (dd, $J$ $\left.=13.0,7.0 \mathrm{~Hz}, 1 \mathrm{H}, \mathrm{OCH}_{2 \mathrm{a}}\right)^{\prime}, 4.23(\mathrm{~d}, J=8.0 \mathrm{~Hz}, 1 \mathrm{H}, \mathrm{H}-20 \mathrm{~b}), 4.31(\mathrm{~s}, 1 \mathrm{H}, 1-\mathrm{OH}), 4.44$ (d, $J=7.5 \mathrm{~Hz}, 1 \mathrm{H}, \mathrm{H}-20 \mathrm{a}), 4.55$ (br, $1 \mathrm{H}, \mathrm{OCH}_{2 \mathrm{a}}$ ), 4.69 (d, $\left.J=10.0 \mathrm{~Hz}, 1 \mathrm{H}, \mathrm{H}-5\right), 4.77$ (d, $J=8.0 \mathrm{~Hz}, 1 \mathrm{H}, \mathrm{H}-3), 4.94$ (d, $J=4.0 \mathrm{~Hz}, 1 \mathrm{H}, \mathrm{H}-2$ '), 5.61 (d, $J=7.5 \mathrm{~Hz}, 1 \mathrm{H}, \mathrm{H}-2)$, 5.63-5.66 (overlap, 1H, $\mathrm{CH}=\mathrm{CH}), 5.72(\mathrm{dt}, J=15.5,6.3 \mathrm{~Hz}, 1 \mathrm{H}, \mathrm{CH}=\mathrm{CH}), 5.93(\mathrm{dd}, J$ $=9.5,4.0 \mathrm{~Hz}, 1 \mathrm{H}, \mathrm{H}-3$ ') $, 6.20(\mathrm{t}, J=8.3 \mathrm{~Hz}, 1 \mathrm{H}, \mathrm{H}-13), 7.30-7.68(\mathrm{~m}, 11 \mathrm{H}, \mathrm{Ar}), 7.82$ $(\mathrm{dd}, J=8.5,1.5 \mathrm{~Hz}, 2 \mathrm{H}, \mathrm{Ar}), 7.93(\mathrm{~d}, J=9.5 \mathrm{~Hz}, 1 \mathrm{H}, \mathrm{NH}), 8.20(\mathrm{dd}, J=8.0,1,0 \mathrm{~Hz}, 1 \mathrm{H}$,

Ar); ${ }^{13} \mathrm{C}$ NMR (125MHz, Acetone- $\left.d_{6}\right) \delta$-5.4, -5.0, 14.4, 14.7, 18.8, 22.4, 23.2, 26.0, $26.8,28.2,28.8,35.0,37.4,43.6,43.7,56.8,70.7,71.6,72.0,73.8,76.3,76.5,76.6$, $78.5,85.9,93.0,128.2,128.3,128.5,129.2,129.3,129.4,130.4,131.2,131.5,132.1$, 133.3 , 134.1, 135.8, 136.3, 139.5, 139.9, 146.5, 153.7, 166.7, 167.6, 170.5, 172.1, 193.1; HRMS (ESI, [M+Na $\left.{ }^{+}\right]$) m/z calcd for $\mathrm{C}_{57} \mathrm{H}_{71} \mathrm{NO}_{13} \mathrm{SiNa}$ : 1028.4592; Found: 1005.4547.

\section{General experimental procedure for compounds 9a and 9c}

To a solution of $8 \mathbf{a}(22 \mathrm{mg}, 0.0225 \mathrm{mmol})$ in ethyl acetate $(0.7 \mathrm{~mL})$ was added $\mathrm{Pd} / \mathrm{C}$ 
(3.3 mg). The reaction mixture was stirred under hydrogen atmosphere for $5 \mathrm{~h}$ at room temperature then diluted with ethyl acetate. After filtration, the solvent was removed by reduced pressure to give a crude product $9 \mathbf{a}(20 \mathrm{mg})$ as a white solid and the crude product can be used directly.

\section{2'-tert-butyldimethylsilyl-9-O-methyl-10-dehydro-7-8-seco-10-deacetyl paclitaxel} (10)

To a mixture of $5(40 \mathrm{mg}, 0.04324 \mathrm{mmol})$ and potassium carbonate (42 $\mathrm{mg}, 0.304$ $\mathrm{mmol})$ in DMF $(0.65 \mathrm{~mL})$ was added iodomethane $(22 \mu \mathrm{L} 0.353 \mathrm{mmol})$ dropwise at $0^{\circ} \mathrm{C}$. The reaction mixture was stirred for $4 \mathrm{~h}$ at $20^{\circ} \mathrm{C}$ and then diluted with ethyl acetate. The organic phase was washed with saturated aqueous $\mathrm{NH}_{4} \mathrm{Cl}$. The organic layer dried over anhydrous $\mathrm{Na}_{2} \mathrm{SO}_{4}$ and then concentrated under reduced pressure. Purification of the crude product by silica gel chromatography (ethyl acetate : petroleum ether $=1: 1.5)$ gave product 10 as a white solid $(28 \mathrm{mg}, 69.0 \%$ yield $):{ }^{1} \mathrm{H}$ NMR (400 MHz, $\left.\mathrm{CDCl}_{3}\right) \delta-0.32\left(\mathrm{~s}, 3 \mathrm{H}, \mathrm{Si}\left(\mathrm{CH}_{3}\right)_{2}\right),-0.09$ (s, 3H, $\left.\mathrm{Si}\left(\mathrm{CH}_{3}\right)_{2}\right), 0.77$ (s, 9H, $\left.\mathrm{SiC}\left(\mathrm{CH}_{3}\right)_{3}\right), 1.20\left(\mathrm{~s}, 3 \mathrm{H}, \mathrm{CH}_{3}\right), 1.28\left(\mathrm{~s}, 3 \mathrm{H}, \mathrm{CH}_{3}\right), 1.81$ (br, 3H, $\left.\mathrm{CH}_{3}\right), 1.87$ (br, 3H, $\mathrm{CH}_{3}$ ), 1.97 (s, 3H, $\mathrm{CH}_{3}$ ), 2.03-2.27 (overlap, 2H, H-6b, H-14b), 2.65-2.73 (br, 2H, H-6a, H-14a), 3.72 (s, 3H, $\mathrm{OCH}_{3}$ ), 3.77 (br, 1H, H-7b), 3.96 (br, 1H, H-7a), 4.19 (br, 1H, H-20b), 4.27 (d, $J=8.0 \mathrm{~Hz}, 1 \mathrm{H}, \mathrm{H}-3), 4.69$ (s, 1H, H-2'), 5.26 (overlap, 1H, H-20a), $5.27(\mathrm{~d}, J=11.2 \mathrm{~Hz}, 1 \mathrm{H}, \mathrm{H}-5), 5.58(\mathrm{~d}, J=9.6 \mathrm{~Hz}, 1 \mathrm{H}, \mathrm{H}-2), 5.90(\mathrm{~d}, J=$ 9.2Hz, 1H, H-3'), 6.30 (t, $J=8.4 \mathrm{~Hz}, \mathrm{H}-13), 7.29-7.59$ (m, 11H, Ar), 7.63 (d, $J=$ 7.6Hz, 2H, Ar), 8.09 (d, $J=7.6 \mathrm{~Hz}, 2 \mathrm{H}, \mathrm{Ar})$; MS (ESI) $m / z[\mathrm{M}+\mathrm{H}]^{+} 940.2$.

2'-tert-butyldimethylsilyl-7-O-methyl-10-dehydro-7-8-seco-10-deacetyl paclitaxel (11)

To a solution of 5 (48 mg, $0.0519 \mathrm{mmol})$ and 2,6-di-tert-butyl-4-methylpyridine $(62 \mu \mathrm{L}, \quad 0.446 \mathrm{mmol})$ in dichloromethane $(0.8 \mathrm{~mL})$ was added methyl trifluoromethanesulfonate $(41 \mu \mathrm{L}, 0.362 \mathrm{mmol})$ at $0^{\circ} \mathrm{C}$, the reaction mixture was stirred for $2 \mathrm{~h}$ at $0^{\circ} \mathrm{C}$ and then another portion of methyl trifluoromethanesulfonate $(20$ $\mu \mathrm{L})$ and 2,6-di-tert-butyl-4-methylpyridine $(30 \mu \mathrm{L})$ was added again. The reaction mixture was stirred at room temperature. After $1 \mathrm{~h}$, the third portion of methyl 
trifluoromethanesulfonate $(20 \mu \mathrm{L})$ and 2,6-di-tert-butyl-4-methylpyridine (30 $\mu \mathrm{L})$ was added and the reaction mixture was stirred at the same temperature for another $1 \mathrm{~h}$ and then diluted with ethyl acetate. The mixture was washed with saturated aqueous $\mathrm{Na}_{2} \mathrm{CO}_{3}$ and saturated aqueous $\mathrm{NH}_{4} \mathrm{Cl}$. The organic layer dried over anhydrous $\mathrm{Na}_{2} \mathrm{SO}_{4}$ and then concentrated under reduced pressure. Purification of the crude product by silica gel chromatography (acetone : petroleum ether $=1: 4$ ) gave product 11 as a white solid (11 mg, 22.6\% yield): ${ }^{1} \mathrm{H}$ NMR (300 MHz, $\left.\mathrm{CDCl}_{3}\right) \delta-0.27(\mathrm{~s}, 3 \mathrm{H}$, $\left.\mathrm{Si}\left(\mathrm{CH}_{3}\right)_{2}\right),-0.05\left(\mathrm{~s}, 3 \mathrm{H}, \mathrm{Si}\left(\mathrm{CH}_{3}\right)_{2}\right), 0.81\left(\mathrm{~s}, 9 \mathrm{H}, \mathrm{SiC}\left(\mathrm{CH}_{3}\right)_{3}\right), 1.10\left(\mathrm{~s}, 3 \mathrm{H}, \mathrm{CH}_{3}\right), 1.22(\mathrm{~s}$, $\left.3 \mathrm{H}, \mathrm{CH}_{3}\right), 1.85\left(\mathrm{~s}, 3 \mathrm{H}, \mathrm{CH}_{3}\right), 1.97$ (br, 6H, $\left.2 \times \mathrm{CH}_{3}\right), 1.97-2.10(\mathrm{~m}, 1 \mathrm{H}, \mathrm{H}-6 \mathrm{~b})$, 2.23-2.36 (m, 1H, H-14b), 2.68-2.80 (m, 2H, H-6a, H-14a), 3.23 (s, 3H, $\left.\mathrm{OCH}_{3}\right), 3.53$ (br, 2H, H-7a, H-7b), 4.32 (m, 2H, H-3, H-20b), 4.70 (s, 1H, H-2'), 5.21 (m, 2H, H-20a, H-5), 5.63 (d, $J=9.0 \mathrm{~Hz}, 1 \mathrm{H}, \mathrm{H}-2), 5.75$ (d, $J=9.3 \mathrm{~Hz}, 1 \mathrm{H}, \mathrm{H}-3$ '), 6.20 (t, $J=$ 7.5Hz, 1H, H-13), 6.42 (s, 1H, 9-OH), $7.11(\mathrm{~d}, J=9.0 \mathrm{~Hz}, 1 \mathrm{H}, \mathrm{NH}), 7.31-7.65$ (m, $11 \mathrm{H}, \operatorname{Ar}), 7.75(\mathrm{~d}, J=7.2 \mathrm{~Hz}, 2 \mathrm{H}, \mathrm{Ar}), 8.14(\mathrm{~d}, J=7.5 \mathrm{~Hz}, 2 \mathrm{H}, \mathrm{Ar}) ; \mathrm{MS}(\mathrm{ESI}) \mathrm{m} / \mathrm{z}[\mathrm{M}+$ $\mathrm{H}]^{+} 940.4$.

\section{General procedure for the syntheses of compounds $1 \mathrm{a} \sim 1 \mathrm{~d}$ and $1 \mathrm{f} \sim 1 \mathrm{j}$ Macrocyclic Taxoid 1a}

To a solution of of $8 \mathbf{a}(20 \mathrm{mg}, 0.0205 \mathrm{mmol})$ in acetonitrile $(0.9 \mathrm{ml})$ was added dropwise $0.35 \mathrm{ml}$ of $\mathrm{HF} /$ pyridine $(\mathrm{v}: \mathrm{v}=1: 2)$ at $0{ }^{\circ} \mathrm{C}$, and the reaction mixture was stirred at room temperature for $30 \mathrm{~h}$. The reaction was quenched with saturated aqueous $\mathrm{NaHCO}_{3}$, diluted with ethyl acetate, washed with saturated $\mathrm{NH}_{4} \mathrm{Cl}$. The organic layer dried over anhydrous $\mathrm{Na}_{2} \mathrm{SO}_{4}$ and then concentrated under reduced pressure. Purification of the crude product by silica gel chromatography (ethyl acetate $:$ petroleum ether $=1: 1.4)$ gave product $1 \mathrm{a}$ as a white solid $(11 \mathrm{mg}, 62.3 \%$

yield): ${ }^{1} \mathrm{H}$ NMR (500 MHz, $\left.\mathrm{CDCl}_{3}\right) \delta 1.17\left(\mathrm{~s}, 3 \mathrm{H}, \mathrm{CH}_{3}\right), 1.21\left(\mathrm{~s}, 3 \mathrm{H}, \mathrm{CH}_{3}\right), 1.68(\mathrm{~s}$, $1 \mathrm{H}, \mathrm{CH}_{3}$ ), 1.96-2.02 (m, 1H, H-6b), 2.35 (s, 3H, $\mathrm{CH}_{3}$ ), 2.28-2.38 (overlap, 2H, H-14b, H-14a), 2.55 (s, 3H, $\mathrm{CH}_{3}$ ), 2.83-2.89 (m, 1H, H-6a), 3.50-3.60 (m, 2H, H-7a, H-7b), $3.62\left(\mathrm{br}, 1 \mathrm{H}, 2^{\prime}-\mathrm{OH}\right), 3.83\left(\mathrm{dd}, J=14.0,7.0 \mathrm{~Hz}, 1 \mathrm{H}, 7-\mathrm{OCH}_{2 \mathrm{~b}} \mathrm{CH}=\mathrm{CH}\right), 4.21(\mathrm{~d}, J=$ $\left.14.0 \mathrm{~Hz}, 1 \mathrm{H}, 7-\mathrm{OCH}_{2 \mathrm{a}} \mathrm{CH}=\mathrm{CH}\right), 4.32(\mathrm{~d}, J=8.5 \mathrm{~Hz}, 1 \mathrm{H}, \mathrm{H}-20 \mathrm{~b}), 4.42(\mathrm{~d}, J=8.0 \mathrm{~Hz}$, 
1H, H-20a), 4.61 (m, 2H, 9-OCH $\left.\mathrm{CH}_{2} \mathrm{CH}\right), 4.74$ (d, $\left.J=7.0 \mathrm{~Hz}, 1 \mathrm{H}, \mathrm{H}-3\right), 4.80$ (s, 1H, H-2'), 5.22 (m, 1H, H-5), 5.54 (d, $J=7.5 \mathrm{~Hz}, 1 \mathrm{H}, \mathrm{H}-2), 5.81$ (d, $J=9.0 \mathrm{~Hz}, 1 \mathrm{H}, \mathrm{H}-3$ '), 5.93-6.02 (m, 2H, CH=CH), $6.16(\mathrm{t}, J=8.5 \mathrm{~Hz}, 1 \mathrm{H}, \mathrm{H}-13), 7.06(\mathrm{~d}, J=9.0 \mathrm{~Hz}, 1 \mathrm{H}$, $\mathrm{NH}), 7.33-7.65(\mathrm{~m}, 11 \mathrm{H}, \mathrm{Ar}), 7.76(\mathrm{~d}, J=7.5 \mathrm{~Hz}, 2 \mathrm{H}, \mathrm{Ar}), 8.15$ (d, $J=8.0 \mathrm{~Hz}, 2 \mathrm{H}, \mathrm{Ar})$;

${ }^{13} \mathrm{C}$ NMR $\left(150 \mathrm{MHz}, \mathrm{CDCl}_{3}\right) \delta 13.8,13.9,21.1,22.6,26.2,33.3,36.2,42.4,42.7,54.8$, 69.3, 71.7, 71.8, 73.2, 73.7, 75.2, 76.5, 78.4, 84.6, 90.6, 127.0, 128.3, 128.7, 129.0, $129.1,129.5,130.1,132.0,133.7,133.8,137.8,137.96,138.03,138.6,145.2,149.9$, $166.8, \quad 166.9, \quad 169.6,172.2,193.7$; HRMS (ESI, $\left.\left[\mathrm{M}+\mathrm{Na}^{+}\right]\right) \mathrm{m} / \mathrm{z}$ calcd for $\mathrm{C}_{49} \mathrm{H}_{53} \mathrm{NO}_{13} \mathrm{Na}, 886.3415$; Found: 886.3430.

\section{Macrocyclic Taxoid 1b}

Yield of $72.6 \%$, white solid; ${ }^{1} \mathrm{H}$ NMR $\left(400 \mathrm{MHz}, \mathrm{CDCl}_{3}\right) \delta 1.14\left(\mathrm{~s}, 3 \mathrm{H}, \mathrm{CH}_{3}\right), 1.20(\mathrm{~s}$, 3H, $\mathrm{CH}_{3}$ ), 1.68 (s, 1H, $\mathrm{CH}_{3}$ ), 2.04 (br, 1H, H-6b), 2.23-2.53 (overlap, 5H, H-14a, H-14b, $\left.\mathrm{OCH}_{2} \mathrm{CH}_{2}, \mathrm{H}-6 \mathrm{a}\right), 2.34$ (s, 3H, $\left.\mathrm{CH}_{3}\right), 2.45$ (s, 1H, $\left.\mathrm{CH}_{3}\right), 3.43$ (m, 1H, H-7a), 3.57-3.62 (overlap, 1H, H-7b), 3.61 (s, 1H, 2'-OH), 3.78 (dd, $J=13.2,6.8 \mathrm{~Hz}, 1 \mathrm{H}$, $\left.\mathrm{OCH}_{2 \mathrm{~b}} \mathrm{CH}=\mathrm{CH}\right), 4.05-4.68\left(\mathrm{~m}, 6 \mathrm{H}, \mathrm{OCH}_{2 \mathrm{a}} \mathrm{CH}=\mathrm{CH}, \mathrm{OCH}_{2} \mathrm{CH}_{2} \mathrm{CH}=\mathrm{CH}, \mathrm{H}-20 \mathrm{a}, \mathrm{H}-20 \mathrm{~b}\right.$, H-5), 4.75 (d, $J=8.0 \mathrm{~Hz}, 1 \mathrm{H}, \mathrm{H}-3$ ), 4.78 (br, 1H, H-2'), 5.58 (d, J = 8.0Hz, 1H, H-2), $5.70(\mathrm{dt}, 1 \mathrm{H}, J=15.2,5.6 \mathrm{~Hz}, \mathrm{CH}=\mathrm{CH}), 5.80$ (d, $J=8.8 \mathrm{~Hz}, 1 \mathrm{H}, \mathrm{H}-3$ ') , 5.86-5.90 (m, $1 \mathrm{H}, \mathrm{CH}=\mathrm{CH}), 6.15(\mathrm{t}, J=8.4 \mathrm{~Hz}, 1 \mathrm{H}, \mathrm{H}-13), 7.04(\mathrm{~d}, J=8.8 \mathrm{~Hz}, 1 \mathrm{H}, \mathrm{NH}), 7.31-7.64$ $(\mathrm{m}, 11 \mathrm{H}, \mathrm{Ar}), 7.73$ (d, $J=7.6 \mathrm{~Hz}, 2 \mathrm{H}, \mathrm{Ar}), 8.16$ (d, $J=7.6 \mathrm{~Hz}, 2 \mathrm{H}, \mathrm{Ar}) .{ }^{13} \mathrm{C} \mathrm{NMR}$ $\left(100 \mathrm{MHz}, \mathrm{CDCl}_{3}\right) \delta 13.8,13.9,20.9,21.0,22.5,26.1,32.6,32.9,36.2,42.7,42.8$, 54.8, 60.4, 70.6, 71.8, 73.1, 75.1, 75.8, 76.2, 78.6, 85.1, 91.3, 126.96, 127.02, 128.2, 128.67, 128.71, 129.0, 129.2, 130.1, 131.0, 131.9, 133.68, 133.75, 134.5, 137.0, 138.1, 144.8, 151.9, 167.0, 169.6, 172.4, 192.2; HRMS (ESI, $\left.\left[\mathrm{M}+\mathrm{Na}^{+}\right]\right) \mathrm{m} / \mathrm{z}$ calcd for $\mathrm{C}_{50} \mathrm{H}_{55} \mathrm{NO}_{13} \mathrm{Na}$ : 900.3571; Found: 900.3589.

\section{Macrocyclic Taxoid 1c}

Yield of 58.6\%, white solid; ${ }^{1} \mathrm{H}$ NMR $\left(500 \mathrm{MHz}, \mathrm{CDCl}_{3}\right) \delta 1.17\left(\mathrm{~s}, 3 \mathrm{H}, \mathrm{CH}_{3}\right), 1.21(\mathrm{~s}$, $3 \mathrm{H}, \mathrm{CH}_{3}$ ), 1.66 (s, 1H, $\mathrm{CH}_{3}$ ), 1.80 (br, 1H, H-6b), 1.80-1.90 (overlap, 2H, H-14a, H-14b), 2.22-2.46 (overlap, 5H, 9- $\mathrm{OCH}_{2} \mathrm{CH}_{2} \mathrm{CH}_{2}, \mathrm{H}-6 \mathrm{a}$ ), 2.35 (s, 3H, $\mathrm{CH}_{3}$ ), 2.60 (s, 
3H, $\mathrm{CH}_{3}$ ), 3.51-3.61 (overlap, 2H, H-7a, H-7b), 3.57 (d, J = 5.0Hz, 1H, 2'-OH), 3.67 $\left(\mathrm{m}, 1 \mathrm{H}, \mathrm{OCH}_{2 \mathrm{~b}}\right), 3.89\left(\mathrm{dd}, J=13.0,8.0 \mathrm{~Hz}, 1 \mathrm{H}, \mathrm{OCH}_{2 \mathrm{~b}}\right.$ ), $4.03(\mathrm{dd}, J=13.0 \mathrm{~Hz}, 7.0 \mathrm{~Hz}$, $1 \mathrm{H}, \mathrm{OCH}_{2 \mathrm{a}}$ ), 4.35 (d, J=7.5Hz, 1H, H-20b), 4.44 (d, J=8.5Hz, 1H, H-20a), 4.69 (d, $J=11.5 \mathrm{~Hz}, 1 \mathrm{H}, \mathrm{H}-5), 4.68-4.71$ (overlap, $1 \mathrm{H}, \mathrm{OCH}_{2 \mathrm{a}}$ ), 4.75 (d, $J=8.0 \mathrm{~Hz}, 1 \mathrm{H}, \mathrm{H}-3$ ), $4.78\left(\mathrm{dd}, J=4.5,2.5 \mathrm{~Hz}, 1 \mathrm{H}, \mathrm{H}-2^{\prime}\right), 5.54(\mathrm{ddd}, J=15.3 \mathrm{~Hz}, 8.0 \mathrm{~Hz}, 5.2 \mathrm{~Hz}, 1 \mathrm{H}$, $\mathrm{CH}=\mathrm{CH}), 5.59(\mathrm{~d}, J=7.5 \mathrm{~Hz}, 1 \mathrm{H}, \mathrm{H}-2), 5.70(\mathrm{dt}, J=15.2,7.0 \mathrm{~Hz}, 1 \mathrm{H}, \mathrm{CH}=\mathrm{CH}), 5.80$ (dd, 1H, $J=9.0,2.0 \mathrm{~Hz}, \mathrm{H}-3$ '), 6.17 (t, $J=8.8 \mathrm{~Hz}, 1 \mathrm{H}, \mathrm{H}-13$ ), 7.04 (d, $J=9.0 \mathrm{~Hz}, 1 \mathrm{H}$, $\mathrm{NH}), 7.31-7.65$ (m, 11H, Ar), 7.74 (d, $J=7.5 \mathrm{~Hz}, 2 \mathrm{H}, \mathrm{Ar}), 8.17$ (d, $J=7.5 \mathrm{~Hz}, 2 \mathrm{H}, \mathrm{Ar})$; ${ }^{13} \mathrm{C}$ NMR $\left(125 \mathrm{MHz}, \mathrm{CDCl}_{3}\right) \delta 13.9,14.2,21.4,22.5,23.2,26.2,27.7,28.1,33.2,36.4$, $42.6,54.7,60.4,70.5,71.4,71.8,74.0,75.1,76.4,78.6,85.3,93.2,126.97,127.02$, 128.2, 128.69, 128.74, 129.0, 129.2, 130.1, 130.7, 131.9, 132.8, 133.7, 133.8, 137.2, 137.6, 138.0, 144.9, 152.9, 166.87, 166.91, 169.7, 172.3, 192.4; HRMS (ESI, $\left.\left[\mathrm{M}+\mathrm{Na}^{+}\right]\right) \mathrm{m} / \mathrm{z}$ calcd for $\mathrm{C}_{51} \mathrm{H}_{57} \mathrm{NO}_{13} \mathrm{Na}$ : 914.3728; Found: 914.3727 .

\section{Macrocyclic Taxoid 1d}

Yield of 41.1\% ( i\&h, two steps), white solid; ${ }^{1} \mathrm{H}$ NMR (400 MHz, $\left.\mathrm{CDCl}_{3}\right) \delta 1.17$ (s, $\left.3 \mathrm{H}, \mathrm{CH}_{3}\right), 1.23\left(\mathrm{~s}, 3 \mathrm{H}, \mathrm{CH}_{3}\right), 1.44-1.90\left(\mathrm{~m}, 4 \mathrm{H}, \mathrm{OCH}_{2} \mathrm{CH}_{2} \mathrm{CH}_{2} \mathrm{CH}_{2} \mathrm{O}\right), 1.68(\mathrm{~s}, 1 \mathrm{H}$, $\mathrm{CH}_{3}$ ), 1.90-2.41 (m, 4H, H-6b, H-14a, H-14b, H-6a), 2.35 (s, 3H, CH $), 2.61$ (s, 3H, $\left.\mathrm{CH}_{3}\right), 3.26\left(\mathrm{~m}, 2 \mathrm{H}, \mathrm{OCH}_{2}\right), 3.56\left(\mathrm{~m}, 1 \mathrm{H}, \mathrm{OCH}_{2 \mathrm{~b}}\right), 3.63\left(\mathrm{~d}, J=3.6 \mathrm{~Hz}, 1 \mathrm{H}, 2^{\prime}-\mathrm{OH}\right)$, 3.72-3.75 (m, 1H, $\left.\mathrm{OCH}_{2 \mathrm{a}}\right), 4.12\left(\mathrm{~m}, 1 \mathrm{H}, \mathrm{OCH}_{2 \mathrm{~b}}\right.$ ), 4.29 (overlap, $1 \mathrm{H}, \mathrm{OCH}_{2 \mathrm{a}}$ ), $4.34(\mathrm{~d}$, $J=8.0 \mathrm{~Hz}, 1 \mathrm{H}, \mathrm{H}-20 \mathrm{~b}), 4.53(\mathrm{~d}, J=8.0 \mathrm{~Hz}, 1 \mathrm{H}, \mathrm{H}-20 \mathrm{a}), 4.68$ (d, $J=9.2 \mathrm{~Hz}, 1 \mathrm{H}, \mathrm{H}-3)$, 4.81 (s, 1H, H-2'), 4.87 (d, J = 7.2Hz, 1H, H-5), 5.59 (d, J=7.6Hz, 1H, H-2), 5.82 (d, $\left.J=9.2 \mathrm{~Hz}, 1 \mathrm{H}, \mathrm{H}-3^{\prime}\right), 6.18(\mathrm{t}, J=8.2 \mathrm{~Hz}, 1 \mathrm{H}, \mathrm{H}-13), 7.09$ (d, $\left.J=8.8 \mathrm{~Hz}, 1 \mathrm{H}, \mathrm{NH}\right)$, 7.32-7.66 (m, 11H, Ar), 7.77 (d, $J=7.6 \mathrm{~Hz}, 2 \mathrm{H}, \mathrm{Ar}), 8.16$ (d, $J=7.6 \mathrm{~Hz}, 2 \mathrm{H}, \mathrm{Ar}) ;{ }^{13} \mathrm{C}$ NMR $\left(100 \mathrm{MHz}, \mathrm{CDCl}_{3}\right) \delta 14.0,14.9,21.3,22.5,25.1,25.7,26.2,33.6,36.6,42.6$, $42.7,54.7,66.8,68.6,70.8,71.7,73.2,75.5,76.4,78.3,84.6,89.4,126.97,127.01$, $128.2,128.7,128.9,129.1,130.1,132.0,133.7,133.8,136.6,138.0,138.1,145.0$, 151.7, 166.7, 166.8, 169.7, 172.1, 191.7. HRMS (ESI, $\left.\left[\mathrm{M}+\mathrm{Na}^{+}\right]\right) \mathrm{m} / \mathrm{z}$ calcd for $\mathrm{C}_{49} \mathrm{H}_{55} \mathrm{NO}_{13} \mathrm{Na}$ : 888.3571; Found: 888.3587. 


\section{Macrocyclic Taxoid 1f}

Yield of $49.8 \%$ ( i\&h, two steps), white solid; ${ }^{1} \mathrm{H}$ NMR (500 MHz, $\left.\mathrm{CDCl}_{3}\right) \delta 1.18$ (s, $\left.3 \mathrm{H}, \mathrm{CH}_{3}\right), 1.22$ (s, 3H, $\left.\mathrm{CH}_{3}\right), 1.30-1.43,1.51-1.61,1.65-1.72,1.89-1.95,2.06-2.14$, 2.18-2.24 (m, 10H, $\left.\mathrm{OCH}_{2}\left(\mathrm{CH}_{2}\right)_{4} \mathrm{CH}_{2} \mathrm{O}, \mathrm{H}-6 \mathrm{~b}, \mathrm{H}-14 \mathrm{~b}\right), 1.68\left(\mathrm{~s}, 1 \mathrm{H}, \mathrm{CH}_{3}\right), 1.87(\mathrm{~s}, 1 \mathrm{H}$, OH), 2.29-2.39 (m, 2H, H-6a, H-14a), 2.37 (s, 3H, $\left.\mathrm{CH}_{3}\right), 2.54$ (s, 3H, $\left.\mathrm{CH}_{3}\right), 3.26$ (td, $J$ $\left.=11.5 \mathrm{~Hz}, 4.3 \mathrm{~Hz}, 1 \mathrm{H}, \mathrm{OCH}_{2 \mathrm{~b}}\right), 3.41-3.50,3.97-4.02,4.41-4.46\left(\mathrm{~m}, 5 \mathrm{H}, \mathrm{OCH}_{2 \mathrm{a}}, 2\right.$ $\left.\times \mathrm{OCH}_{2}\right), 3.52\left(\mathrm{~d}, J=4.5 \mathrm{~Hz}, 1 \mathrm{H}, 2^{\prime}-\mathrm{OH}\right), 4.35$ (d, $\left.J=8.5 \mathrm{~Hz}, 1 \mathrm{H}, \mathrm{H}-20 \mathrm{~b}\right), 4.45$ (d, $J=$

$8.5 \mathrm{~Hz}, 1 \mathrm{H}, \mathrm{H}-20 \mathrm{a}), 4.62$ (dd, $J=10.8,2.3 \mathrm{~Hz}, 1 \mathrm{H}, \mathrm{H}-5), 4.77$ (d, $J=7.0 \mathrm{~Hz}, 1 \mathrm{H}, \mathrm{H}-3$ ), $4.79(\mathrm{dd}, J=4.0,2.5 \mathrm{~Hz}, 1 \mathrm{H}, \mathrm{H}-2$ ') 5.59 (d, $J=7.5 \mathrm{~Hz}, 1 \mathrm{H}, \mathrm{H}-2), 5.81$ (dd, $J=9.0$, 2.0Hz, 1H, H-3'), 6.18 (t, $J=8.3 \mathrm{~Hz}, 1 \mathrm{H}, \mathrm{H}-13$ ), 7.02 (d, $J=9.0 \mathrm{~Hz}, 1 \mathrm{H}, \mathrm{NH}$ ), 7.32-7.65 (m, 11H, Ar), 7.75 (d, $J=7.0 \mathrm{~Hz}, 2 \mathrm{H}, \mathrm{Ar}), 8.18$ (d, $J=7.5 \mathrm{~Hz}, 2 \mathrm{H}, \mathrm{Ar}) ;{ }^{13} \mathrm{C}$ NMR $\left(125 \mathrm{MHz}, \mathrm{CDCl}_{3}\right) \delta 13.9,21.3,22.5,23.7,23.8,26.2,28.5,29.5,32.5,36.3$, 42.6, 42.7, 54.7, 67.0, 69.7, 71.9, 72.9, 73.1, 75.2, 76.2, 78.6, 85.1, 90.3, 126.96, $127.00,128.3,128.69,128.72,129.0,129.2,130.1,131.9,133.7,133.8,134.7,138.04$, 138.01, 145.1, 152.0, 166.8, 166.9, 169.6, 172.4, 192.3; HRMS (ESI, $\left[\mathrm{M}+\mathrm{H}^{+}\right]$) m/z calcd for $\mathrm{C}_{51} \mathrm{H}_{59} \mathrm{NO}_{13} \cdot \mathrm{H}: 894.4065$; Found: 894.4602 .

\section{Macrocyclic Taxoid $1 \mathrm{~g}$}

Yield of 77.2\%, white solid; ${ }^{1} \mathrm{H}$ NMR $\left(500 \mathrm{MHz}, \mathrm{CDCl}_{3}\right) \delta 1.17\left(\mathrm{~s}, 3 \mathrm{H}, \mathrm{CH}_{3}\right), 1.23$ (s, $\left.3 \mathrm{H}, \mathrm{CH}_{3}\right), 1.68\left(\mathrm{br}, 3 \mathrm{H}, \mathrm{CH}_{3}\right), 1.87(\mathrm{~s}, 1 \mathrm{H}, 1-\mathrm{OH}), 2.36\left(\mathrm{~s}, 3 \mathrm{H}, \mathrm{CH}_{3}\right), 2.18-2.24(\mathrm{~m}$, 1H, H-6b), 2.32-2.36 (overlap, 3H, H-14b, 9- $\mathrm{OCH}_{2} \mathrm{CH}_{2}$ ), 2.60 (s, 3H, $\mathrm{CH}_{3}$ ), 2.58-2.70 (m, 2H, H-14 $\left.{ }^{\mathrm{a}}, \mathrm{H}-6^{\mathrm{a}}\right), 3.40-3.48$ (m, 2H, H-7b, H-7 $), 3.55$ (d, J = 4.5Hz, 1H, 2'-OH), 3.88-3.98, 4.10-4.16 (m, 4H, 9- $\left.\mathrm{OCH}_{2}, 7-\mathrm{OCH}_{2}\right), 4.35$ (d, J =9.0Hz, 1H, H-20b), 4.48 $\left(\mathrm{d}, J=8.5 \mathrm{~Hz}, 1 \mathrm{H}, \mathrm{H}-20^{\mathrm{a}}\right), 4.66(\mathrm{dd}, J=11.0,3.5 \mathrm{~Hz}, 1 \mathrm{H}, \mathrm{H}-5), 4.79(\mathrm{dd}, J=4.3$, $2.8 \mathrm{~Hz}, 1 \mathrm{H}, \mathrm{H}-2$ '), 4.83 (d, J = 8.0Hz, 1H, H-3), 5.59 (d, J = 7.5Hz, 1H, H-2), 5.70 (dt, $J=10.5,8.0 \mathrm{~Hz}, 1 \mathrm{H}, \mathrm{CH}=\mathrm{CH}), 5.78(\mathrm{dt}, J=11.0,7.5 \mathrm{~Hz}, 1 \mathrm{H}, \mathrm{CH}=\mathrm{CH}), 5.82(\mathrm{dd}, J=$ 9.0, 2.0Hz, 1H, H-3'), 6.19 (t, $J=8.5 \mathrm{~Hz}, 1 \mathrm{H}, \mathrm{H}-13), 7.04$ (d, $J=9.5 \mathrm{~Hz}, 1 \mathrm{H}, \mathrm{NH})$, 7.34-7.64 (m, 11H, Ar), 7.76 (d, $J=7.5 \mathrm{~Hz}, 2 \mathrm{H}, \mathrm{Ar}), 8.17$ (d, $J=7.5 \mathrm{~Hz}, 2 \mathrm{H}, \mathrm{Ar}) ;{ }^{13} \mathrm{C}$ NMR $\left(125 \mathrm{MHz}, \mathrm{CDCl}_{3}\right) \delta 14.0,14.7,21.4,22.5,26.2,29.3,32.0,36.5,42.6,42.7$, $54.7,63.0,65.1,70.6,72.3,73.2,75.3,76.2,78.5,84.6,90.1,126.95,127.00,128.3$, 
128.67, 128.71, 128.74, 128.76, 129.0, 129.1, 130.0, 130.1, 131.9, 133.7, 133.8, 136.9,

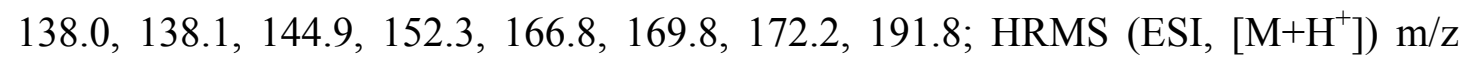
calcd for $\mathrm{C}_{50} \mathrm{H}_{55} \mathrm{NO}_{13} \cdot \mathrm{H}: 878.3752$; Found: 878.3751 .

\section{0-dehydro-7-8-seco-10-deacetyl paclitaxel $1 \mathrm{~h}$}

Yield of 49.1\%, white solid; ${ }^{1} \mathrm{H}$ NMR $\left(500 \mathrm{MHz}, \mathrm{CDCl}_{3}\right) \delta 1.09$ (s, 3H, $\left.\mathrm{CH}_{3}\right), 1.10$ (s, $\left.3 \mathrm{H}, \mathrm{CH}_{3}\right), 1.23\left(\mathrm{~s}, 3 \mathrm{H}, \mathrm{CH}_{3}\right), 1.80\left(\mathrm{~s}, 3 \mathrm{H}, \mathrm{CH}_{3}\right), 1.84$ (s, 3H, $\left.\mathrm{CH}_{3}\right), 2.12$ (overlap, $2 \mathrm{H}$, H-6b, OH), 2.38-2.40 (m, 1H, H-14b), 2.65 (br, 1H, H-14a), 2.78 (br, 1H, H-6a), 3.37 (br, 1H, 2'-OH), 3.71 (br, 1H, H-7b), 3.93 (br, 1H, H-7a), 4.29 (overlap, 1H, H- 20b), 4.29 (d, $J=7.5 \mathrm{~Hz}, 1 \mathrm{H}, \mathrm{H}-3$ ), 4.82 (d, $J=2.5 \mathrm{~Hz}, 1 \mathrm{H}, \mathrm{H}-2$ '), 5.22 (m, 2H, H-5, H-20a), $5.61(\mathrm{~d}, J=9.5 \mathrm{~Hz}, 1 \mathrm{H}, \mathrm{H}-2), 5.90$ (d, $J=7.5 \mathrm{~Hz}, 1 \mathrm{H}, \mathrm{H}-3$ '), 6.22 (t, $J=8.3 \mathrm{~Hz}, 1 \mathrm{H}$, H-13), 6.44 (s, 1H, 9-OH), 7.19 (d, $J=9.5 \mathrm{~Hz}, 1 \mathrm{H}, \mathrm{NH}), 7.31-7.50$ (m, 11H, Ar), 7.69 (d, $J=7.5 \mathrm{~Hz}, 2 \mathrm{H}, \mathrm{Ar}), 8.07$ (d, $J=7.5 \mathrm{~Hz}, 1 \mathrm{H}, \mathrm{Ar}) ;{ }^{13} \mathrm{C}$ NMR $\left(125 \mathrm{MHz}\right.$, Acetone- $\left.d_{6}\right)$ $\delta 14.6,14.8,22.0,22.4,25.5,26.2,29.3,37.9,39.0,43.8,45.4,56.5,59.2,71.1,74.8$, 74.9, 75.6, 87.0, 124.7, 128.21, 128.25, 129.16, 129.23, 129.6, 130.6, 131.5, 132.3, 134.0, 135.4, 137.4, 140.6, 144.2, 150.1, 166.5, 167.6, 169.4, 173.3, 1920; MS (ESI) $\mathrm{m} / \mathrm{z} 812.4\left(\mathrm{M}+\mathrm{H}^{+}\right), 834.3\left(\mathrm{M}+\mathrm{Na}^{+}\right)$.

\section{9-O-methyl-10-dehydro-7-8-seco-10-deacetyl paclitaxel 1i}

Yield of $70.3 \%$, white solid; ${ }^{1} \mathrm{H}$ NMR (500 MHz, $\left.\mathrm{CDCl}_{3}\right) 1.19$ (s, 3H, $\left.\mathrm{CH}_{3}\right), 1.24$ (s, $3 \mathrm{H}, \mathrm{CH}_{3}$ ), 1.82 (br, 3H, $\left.\mathrm{CH}_{3}\right), 1.86$ (br, 6H, $2 \times \mathrm{CH}_{3}$ ), 2.06-2.09 (m, 1H, H-6b), 2.35 (dd, $J=15.5,10.0 \mathrm{~Hz}, 1 \mathrm{H}, \mathrm{H}-14 \mathrm{~b}), 2.62$ (br, 1H, H-6a), 2.77 (br, 1H, H-14a), 3.48 (br, 1H, 2'-OH), 3.71 (s, 3H, 9-OCH 3 ), 3.67-3.71 (overlap, 1H, H-7b), 3.93 (br, 1H, 7-Ha), 4.23 (overlap, $1 \mathrm{H}, \mathrm{H}-20 \mathrm{~b}$ ), 4.26 (d, $J=7.5 \mathrm{~Hz}, 1 \mathrm{H}, \mathrm{H}-3), 4.81$ (d, $J=2.5 \mathrm{~Hz}, 1 \mathrm{H}$, H-2'), 5.23 (br, 2H, H-5, H-20a), 5.59 (d, $J=9.5 \mathrm{~Hz}, 1 \mathrm{H}, \mathrm{H}-2$ ), 5.90 (dd, $J=9.5$, $2.0 \mathrm{~Hz}, 1 \mathrm{H}, \mathrm{H}-3$ '), 6.24 (t, $J=8.0 \mathrm{~Hz}, 1 \mathrm{H}, \mathrm{H}-13$ ), 7.17 (d, $\left.J=9.5 \mathrm{~Hz}, 1 \mathrm{H}, 3^{\prime}-\mathrm{NH}\right)$, 7.31-7.61 (m, 11H, Ar), 7.66 (d, $J=7.5 \mathrm{~Hz}, 2 \mathrm{H}, \mathrm{Ar}), 8.08(\mathrm{~d}, J=8.0 \mathrm{~Hz}, 2 \mathrm{H}, \mathrm{Ar}) .{ }^{13} \mathrm{C}$ NMR $\left(125 \mathrm{MHz}, \mathrm{CDCl}_{3}\right) \delta 14.4,14.8,22.1,23.1,25.2,36.6,37.6,42.6,44.6,42.6$, $44.6,54.5,59.3,59.4,60.4,71.1,73.6,74.3,74.3,80.1,86.8,126.9,127.0,128.2$, $128.7,128.9,129.0,129.1,129.8,132.0,133.5,133.9,137.9,144.6,167.2,167.4$, 
168.8, 172.3, 190.5; HRMS (ESI, $\left[\mathrm{M}+\mathrm{H}^{+}\right]$) m/z calcd for $\mathrm{C}_{46} \mathrm{H}_{51} \mathrm{NO}_{13} \cdot \mathrm{H}: 826.3439$; Found: 826.3441.

\section{7-O-methyl-10-dehydro-7-8-seco-10-deacetyl paclitaxel $1 \mathbf{j}$}

Yield of $73.3 \%$, white solid; ${ }^{1} \mathrm{H}$ NMR (500 MHz, $\left.\mathrm{CDCl}_{3}\right) 1.07$ (s, 3H, $\left.\mathrm{CH}_{3}\right), 1.21$ (s, $\left.3 \mathrm{H}, \mathrm{CH}_{3}\right), 1.63\left(\mathrm{~s}, 3 \mathrm{H}, \mathrm{CH}_{3}\right), 1.83$ (br, 3H, $\left.\mathrm{CH}_{3}\right), 1.85$ (br, $\left.3 \mathrm{H}, \mathrm{CH}_{3}\right), 2.09-2.13(\mathrm{~m}, 1 \mathrm{H}$, H-6b), 2.51-2.66 (m, 3H, H-14b, H-6a, H-14a), 3.26 (s, 3H, $\left.\mathrm{OCH}_{3}\right), 3.29-3.34$ (m, 1H, H-7a), 3.60 (br, 1H, H-7b), 4.14 (br, 1H, H-20b), 4.25 (d, J = 7.5Hz, 1H, H-3), 4.73 (dd, $J=4.0,2.5 \mathrm{~Hz}, 1 \mathrm{H}, \mathrm{H}-2$ ') 5.00 (d, $J=11.5 \mathrm{~Hz}, 1 \mathrm{H}, \mathrm{H}-5), 5.22$ (br, 2H, H-20b, H-20a), 5.60 (d, $J=9.5 \mathrm{~Hz}, 1 \mathrm{H}, \mathrm{H}-2), 5.84$ (dd, $J=9.3,2.3 \mathrm{~Hz}, 1 \mathrm{H}, \mathrm{H}-3$ '), 6.03 (br, $1 \mathrm{H}$, H-13), 6.46 (s, 1H, 9-OH), 7.27-7.64, 7.95-7.96 (m, 12H, Ar, NH), 7.82 (d, J=7.0Hz, 2H, Ar), $7.95(\mathrm{~d}, J=6.5 \mathrm{~Hz}, 2 \mathrm{H}, \mathrm{Ar}) ;{ }^{13} \mathrm{C} \mathrm{NMR}\left(100 \mathrm{MHz}, \mathrm{CDCl}_{3}\right) \delta 14.46,14.54$, $20.8,22.1,25.0,30.9,34.9,36.7,42.7,44.7,54.8,59.1,70.0,73.5,74.6,74.8,80.3$, $85.9,86.3,124.1,127.0,127.1,127.9,128.5,128.6,128.9,129.4,131.7,133.86$, 133.94, 136.6, 138.9, 141.9, 148.8, 166.2, 167.1, 169.0, 172.4, 190.9; HRMS (ESI, $\left.\left[\mathrm{M}+\mathrm{H}^{+}\right]\right) \mathrm{m} / \mathrm{z}$ calcd for $\mathrm{C}_{46} \mathrm{H}_{51} \mathrm{NO}_{13}: 826.3442$; Found: 826.3441 .

\section{Macrocyclic Taxoid 1e}

To a solution of $\mathbf{1 b}(11 \mathrm{mg}, 0.0125 \mathrm{mmol})$ in ethanol $(0.4 \mathrm{~mL})$ was added $\mathrm{Pd} / \mathrm{C}(3.0$ $\mathrm{mg}$ ). The reaction mixture was stirred under hydrogen atmosphere for $5 \mathrm{~h}$ at room temperature and then diluted with ethyl acetate. After filtration, the solution dried over anhydrous $\mathrm{Na}_{2} \mathrm{SO}_{4}$ and then concentrated under reduced pressure. Purification of the crude product by silica gel chromatography (ethyl acetate $:$ petroleum ether $=1: 1.3$ ) gave product $1 \mathrm{e}$ as a white solid (5 mg, $45.4 \%$ yield); ${ }^{1} \mathrm{H}$ NMR $\left(500 \mathrm{MHz}, \mathrm{CDCl}_{3}\right) \delta$ 1.18 (s, 3H, $\left.\mathrm{CH}_{3}\right), 1.23\left(\mathrm{~s}, 3 \mathrm{H}, \mathrm{CH}_{3}\right), 1.41-1.67$ (m, 6H, $\mathrm{OCH}_{2} \mathrm{CH}_{2} \mathrm{CH}_{2} \mathrm{CH}_{2} \mathrm{CH}_{2} \mathrm{O}$ ), 1.70 (s, 1H, $\mathrm{CH}_{3}$ ), 1.82-1.89 (m, 2H, H-6b, H-14b) 1.95-1.97 (m, 1H, H-14a), 2.37 (s, $3 \mathrm{H}, \mathrm{CH}_{3}$ ), 2.38-2.42 (overlap, 1H, H-6a), 2.57 (s, 3H, $\mathrm{CH}_{3}$ ), 3.34-3.44 (m, 2H, $\mathrm{OCH}_{2}$ ), 3.47-3.49 (m, 2H, $\left.\mathrm{OCH}_{2}\right), 3.54\left(\mathrm{~s}, 1 \mathrm{H}, 2^{\prime}-\mathrm{OH}\right), 4.08-4.16\left(\mathrm{~m}, 2 \mathrm{H}, \mathrm{OCH}_{2}\right), 4.34(\mathrm{~d}, J=$ $8.5 \mathrm{~Hz}, 1 \mathrm{H}, \mathrm{H}-20 \mathrm{~b}), 4.47$ (d, $J=8.5 \mathrm{~Hz}, 1 \mathrm{H}, \mathrm{H}-20 \mathrm{a}), 4.58$ (dd, $J=9.5,2.0 \mathrm{~Hz}, 1 \mathrm{H}, \mathrm{H}-3$ ), 4.81 (overlap, 1H, H-2'), 4.81 (d, $J=7.5 \mathrm{~Hz}, 1 \mathrm{H}, \mathrm{H}-5), 5.60$ (d, $J=7.5 \mathrm{~Hz}, 1 \mathrm{H}, \mathrm{H}-2$ ), 
$5.81(\mathrm{dd}, J=9.5,2.0 \mathrm{~Hz}, 1 \mathrm{H}, \mathrm{H}-3$ '), 6.19 (t, $J=8.3 \mathrm{~Hz}, 1 \mathrm{H}, \mathrm{H}-13), 7.03$ (d, $J=9.0 \mathrm{~Hz}$, 1H, NH), 7.33-7.65 (m, 11H, Ar), 7.75 (d, J=7.5Hz, 2H, Ar), 8.17 (d, J=7.5Hz, 2H, $\mathrm{Ar}) ;{ }^{13} \mathrm{C} \mathrm{NMR}\left(125 \mathrm{MHz}, \mathrm{CDCl}_{3}\right) \delta 14.2,14.7,20.1,21.6,26.4,27.1,27.8,31.2,32.6$, $36.7,42.9,43.0,55.0,66.8,66.9,72.1,73.4,73.8,75.6,76.4,78.7,85.3,90.2,127.2$, $127.3,128.5,128.97,128.99,129.2,129.4,130.4,132.2,133.9,134.1,136.0,138.2$, 138.4, 145.4, 152.2, 167.1, 167.2, 170.1, 172.6, 192.3; HRMS (ESI, $\left.\left[\mathrm{M}+\mathrm{H}^{+}\right]\right) \mathrm{m} / \mathrm{z}$ calcd for $\mathrm{C}_{50} \mathrm{H}_{57} \mathrm{NO}_{13} \cdot \mathrm{H}: 880.3908$; Found: 880.3912.

Information about synthesis of taxoids $1 \mathrm{k}-1 \mathrm{o}$ are available in supplemental materials. All tested compounds $(\mathbf{1} \mathbf{k} \sim \mathbf{1 0})$ were $\geq 95 \%$ pure by HPLC

\section{2-debenzoyl-2-(3-azidobenzoyl)-10-dehydro-7-8-seco-10-deacetyl paclitaxel (1k)}

Yield of $76.6 \%$, white solid; ${ }^{1} \mathrm{H}$ NMR $\left(400 \mathrm{MHz}, \mathrm{CDCl}_{3}\right) \delta 1.08\left(\mathrm{~s}, 3 \mathrm{H}, \mathrm{CH}_{3}\right), 1.22$ (s, $\left.3 \mathrm{H}, \mathrm{CH}_{3}\right), 1.78\left(\mathrm{~s}, 3 \mathrm{H}, \mathrm{CH}_{3}\right), 1.83\left(\mathrm{~s}, 3 \mathrm{H}, \mathrm{CH}_{3}\right), 1.86\left(\mathrm{~s}, 3 \mathrm{H}, \mathrm{CH}_{3}\right), 2.03-2.11(\mathrm{~m}, 1 \mathrm{H}$, H-14b), 2.39 (dd, $J=15.6,9.6 \mathrm{~Hz}, 1 \mathrm{H}, \mathrm{H}-6 \mathrm{~b}), 2.59$ (br, 1H, H-14a), 2.80 (br, 1H, H-6a), 3.67-3.73 (m, 1H, H-7b), 3.93 (br, 1H, H-7a), 4.20 (d, J=8.4Hz, 1H, H-20b), 4.28-4.32 (m, 1H, H-3), 4.80 (d, J=2.8Hz, 1H, H-2'), 5.20 (m, 2H, H-5, H-20a), 5.59 (d, $J=8.4 \mathrm{~Hz}, 1 \mathrm{H}, \mathrm{H}-3$ '), 6.18 (d, $J=8.0 \mathrm{~Hz}, 1 \mathrm{H}, \mathrm{H}-13$ ), 6.45 (s, 1H, 9-OH), 7.28-7.41 (m, 6H, Ar), 7.46-7.52 (m, 4H, Ar), 7.62 (s, 1H, Ar), 7.70 (d, J=8.0Hz, 2H, Ar), 7.87 $(\mathrm{d}, J=8.0 \mathrm{~Hz}, 1 \mathrm{H}, \mathrm{Ar}) ;{ }^{13} \mathrm{C} \mathrm{NMR}\left(150 \mathrm{MHz}, \mathrm{CDCl}_{3}\right) \delta 14.5,14.7,21.2,22.2,24.9$, 29.3, 30.9, 31.7, 36.6, 37.5, 43.0, 44.4, 53.8, 54.7, 59.7, 70.7, 73.6, 74.7, 75.2, 80.6, $86.1,120.0,123.0,124.1,124.4,126.1,127.0,128.2$, 128.7, 128.9, 130.6, 131.1, 132.0, 133.7, 138.0, 141.1, 142.1, 148.9, 166.4, 167.1, 168.9, 172.4, 191.0; MS (ESI) $m / z[\mathrm{M}+\mathrm{H}]^{+} 853.2,[\mathrm{M}+\mathrm{Na}]^{+} 875.2$.

\section{2-debenzoyl-2-(3-azidobenzoyl)-macrocyclic Taxoid (11)}

Yield of $55.3 \%$, white solid; ${ }^{1} \mathrm{H}$ NMR (400 MHz, $\left.\mathrm{CDCl}_{3}\right) \delta 1.17\left(\mathrm{~s}, 3 \mathrm{H}, \mathrm{CH}_{3}\right), 1.22(\mathrm{~s}$, $3 \mathrm{H}, \mathrm{CH}_{3}$ ), 1.69 (s, 1H, $\mathrm{CH}_{3}$ ), 2.00 (dd, $\left.J=12.4,6.8 \mathrm{~Hz}, 1 \mathrm{H}, \mathrm{H}-6 \mathrm{~b}\right), 2.30$ (dd, $J=15.6$, 8.4Hz, 1H, H-14b), 2.35(s, 3H, $\left.\mathrm{CH}_{3}\right), 2.38$ (dd, $\left.J=15.6,9.2 \mathrm{~Hz}, 1 \mathrm{H}, \mathrm{H}-14 \mathrm{a}\right), 2.54$ (s, $3 \mathrm{H}, \mathrm{CH}_{3}$ ), 2.81-2.91 (m, 1H, H-6a), 3.49-3.61 (m, 3H, H-7a, H-7b, 2'-OH), 3.84 (dd, 
$\left.J=14.4,7.2 \mathrm{~Hz}, 1 \mathrm{H}, \mathrm{OCH}_{2 \mathrm{~b}} \mathrm{CH}=\mathrm{CH}\right), 4.21\left(\mathrm{~d}, J=14.0 \mathrm{~Hz}, 1 \mathrm{H}, \mathrm{OCH}_{2 \mathrm{a}} \mathrm{CH}=\mathrm{CH}\right), 4.27$ $(\mathrm{d}, J=8.4 \mathrm{~Hz}, 1 \mathrm{H}, \mathrm{H}-2 \mathrm{~b}), 4.61-4.65\left(\mathrm{~m}, 2 \mathrm{H}, \mathrm{CH}=\mathrm{CHCH}_{2} \mathrm{O}\right), 4.75(\mathrm{~d}, J=7.2 \mathrm{~Hz}, 1 \mathrm{H}$, H-3), 4.78 (s, 1H, H-2'), 5.22 (dd, $J=12.0,9.6 \mathrm{~Hz}, 1 \mathrm{H}, \mathrm{H}-5), 5.55$ (d, $J=7.2 \mathrm{~Hz}, 1 \mathrm{H}$, $\mathrm{H}-2), 5.79(\mathrm{dd}, J=9.2,1.6 \mathrm{~Hz}, 1 \mathrm{H}, \mathrm{H}-3$ ') $, 5.97-6.00(\mathrm{~m}, 2 \mathrm{H}, \mathrm{CH}=\mathrm{CH}), 6.14$ (t, $J=$ 7.2Hz, 1H, H-13), 7.00 (d, $J=9.2 \mathrm{~Hz}, 1 \mathrm{H}, \mathrm{NH}), 7.29-7.36$ (m, 2H, Ar), 7.39-7.44 (m, 4H, Ar), 7.47-7.53 (m, 4H, Ar), 7.75 (d, $J=7.2 \mathrm{~Hz}, 2 \mathrm{H}, \mathrm{Ar}$ ), 7.81 (s, 1H, Ar), 7.93 (d, $J=7.6 \mathrm{~Hz}, 1 \mathrm{H}, \mathrm{Ar}) ;{ }^{13} \mathrm{C} \mathrm{NMR}\left(125 \mathrm{MHz}, \mathrm{CDCl}_{3}\right) \delta 13.7,13.9,21.1,22.6,26.1,29.7$, $33.3,36.1,42.3,42.7,54.8,69.3,71.8,73.1,73.8,75.5,78.4,84.6,90.6,115.2,120.3$, 120.7, 124.3, 126.6, 127.0, 127.1, 128.3, 128.7, 129.0, 129.4, 129.6, 130.2, 130.9, 132.0, 133.7, 137.9, 138.0, 138.1, 138.3, 140.9, 145.1, 150.0, 155.5, 166.0, 167.0, 172.3, 193.6; MS (ESI) $m / z[\mathrm{M}+\mathrm{H}]^{+}$905.3, $[\mathrm{M}+\mathrm{Na}]^{+}$927.3.

\section{3'-dephenyl-3'-(2-methyl-1-propyl)-2-debenzoyl-2-(3-azidobenzoyl)-10-dehydro-}

\section{7-8-seco-docetaxel (1n)}

Yield of 48.1\%, white solid; ${ }^{1} \mathrm{H}$ NMR $\left(400 \mathrm{MHz}, \mathrm{CDCl}_{3}\right) \delta 0.97(\mathrm{~d}, J=6.4 \mathrm{~Hz}, 6 \mathrm{H}$, 6'- $\left.-\mathrm{CH}_{3}, 7^{\prime}-\mathrm{CH}_{3}\right), 1.10\left(\mathrm{~s}, 3 \mathrm{H}, \mathrm{CH}_{3}\right), 1.25\left(\mathrm{~s}, 3 \mathrm{H}, \mathrm{CH}_{3}\right), 1.30$ (s, 9H, $\left.\mathrm{OC}\left(\mathrm{CH}_{3}\right)_{3}\right), 1.42$ (m, 1H, H-4'b), 1.60-1.69 (m, 5H, CH $3, \mathrm{H}-4$ 'a, H-5'), 1.84 (s, 3H, $\mathrm{CH}_{3}$ ), 1.89 (s, 3H, $\mathrm{CH}_{3}$ ), 2.01 (m, 1H, H-6b), 2.44 (dd, $\left.J=16.0,10.0 \mathrm{~Hz}, 1 \mathrm{H}, \mathrm{H}-14 \mathrm{~b}\right), 2.50$ (m, 1H, H-6a), 2.82 (m, 1H, H-14a), 3.71 (m, 1H, H-7b), 3.92 (m, 1H, H-7a), 4.15-4.32 (m, 4H, H-2', H-3, H-3', H-20b), 4.73 (br, 1H, NH), 5.24 (br, 2H, H-5, H-20a), 5.60 (d, J $=9.2 \mathrm{~Hz}, 1 \mathrm{H}, \mathrm{H}-2), 6.19(\mathrm{br}, 1 \mathrm{H}, \mathrm{H}-13), 6.45(\mathrm{~s}, 1 \mathrm{H}, 9-\mathrm{OH}), 7.48(\mathrm{t}, J=8.0 \mathrm{~Hz}, 1 \mathrm{H}$, Ar), $7.63(\mathrm{~m}, 1 \mathrm{H}, \mathrm{Ar}), 7.82$ (d, $J=8.8 \mathrm{~Hz}, 1 \mathrm{H}, \mathrm{Ar}), 7.84$ (m, 1H, Ar); ${ }^{13} \mathrm{C}$ NMR $\left(125 \mathrm{MHz}, \mathrm{CDCl}_{3}\right) \delta 14.9,15.2,21.8,22.3,22.9,24.9,26.1,28.3,32.9,36.4,40.5$, $43.3,43.5,51.5,52.0,67.8,70.0,72.8,73.4,80.1,80.4,80.8,81.1,91.0,92.2,94.4$, $119.9,123.3,125.9,126.4,129.8,132.9,137.5,140.5,148.2,156.2,164.0,170.1$, 172.7, 190.1; MS (ESI) $\mathrm{m} / \mathrm{z}[\mathrm{M}+\mathrm{Na}]^{+} 851.4,[\mathrm{M}+\mathrm{K}]^{+} 867.4$.

\section{Cell Assays}

Cytotoxicity evaluation was performed with A2780, A2780AD, (overexpressing P-gp), ${ }^{35}$ human ovarian carcinoma cell lines, Hela and Hela- $\beta$ III 
transfected cells ${ }^{36}$ with the MTT assay modified as previously described. ${ }^{19}$ Cell cycle analysis was performed as previously described. ${ }^{37} \mathrm{~KB}-3-1$ (HeLa cells ) derived from a cervical carcinoma and KB-V1 cells multidrug resistant line are grown in DMEM ,10 \% FCS, $1 \mathrm{mM}$ piruvate and penicillin (50 units/ml) -streptomycin (50 $\mu \mathrm{g} / \mathrm{ml}$ ), the latter cell line with $1 \mu \mathrm{g} / \mathrm{ml}$ of vinblastine (Shen, D-W., Cardarelli, C., Hwang, J., Cornwell, M., Richert, N., Ishii, S., Pastan, I., and Gottesman, M.M.(1986) Multiple drug resistant human KB carcinoma cells independently selected for high-level resistance to colchicine, adryamycin or vinblastine show changes in expression of specific proteins. J. Biol. 261., 7762-7770.). These 2 lines were a generous gift from Dr. Michel M. Gottesman.

\section{Binding Affinity Measurement}

Calf brain tubulin was purified as described. ${ }^{38}$ Glutaraldehyde-stabilized microtubules with active paclitaxel binding sites were prepared as described. ${ }^{39}$ The binding constants of the compounds to these microtubules were measured as previously described. $^{40}$

\section{Molecular Modeling}

Models of 1a-h, 1k and $\mathbf{1 l}$ were built departing from paclitaxel using the MAESTRO graphic interface ${ }^{41}$ integrated in the Schrödinger Suite 2014-3 ${ }^{42}$. Later, the tubulin dimer containing the $\beta$ III isotype was built by homology modeling with Prime Structure Prediction version $3.0^{43}$ employing the 1JFF structure of the tubulin dimer $^{44}$. The sequence of human $\beta$ III-tubulin was this of UniProtKB with code Q13509 (Figure S10).

The first step was to collect the $\beta$-tubulin sequences whose structure is available in NCBI PDB. BLAST with the matrix BLOSUM62 with an expectation value of 10.000 was employed to do so. The $1 \mathrm{JFF}$ was selected due to its higher sequence identity with $\beta I I I$, and its high structural resolution for a tubulin molecule assembled into microtubules. Then, the positions of the backbone atoms and those of the side chains of the conserved residues were kept, and the missing side chains and the 
missing regions with a length lower than 20 residues were added. $\alpha$-tubulin, GTP, GDP and the magnesium ion were added to the resulting structure which was finally optimized using the automatic method implemented in PRIME with the RMS gradient set to $0.01 \mathrm{kcal} / \mathrm{mol} / \AA$. This Automatic method uses conjugate gradient minimization when the gradients are large, and switches to the truncated Newton method when they gradients are small enough. The hydrogen bond acceptation and donation isosurfaces for the paclitaxel binding sites of $\beta$ I- and $\beta$ III- tubulin were calculated with SiteMap $3.2^{45}$ as implemented in the Schrödinger Suite.

Paclitaxel and all the C-seco compounds were manually docked in the paclitaxel sites of $\beta \mathrm{I}-$ and $\beta \mathrm{III}-$ tubulin. The structure was locally optimized and energy minimized employed the Powell-Reeves conjugate gradient (PRCG) method as implemented in Macromodel ${ }^{46}$. In all cases the criteria of convergence was an energy gradient with a value lower than $0.05 \mathrm{~kJ} / \mathrm{mol} / \AA$.

An exhaustive structural study of the binding site was done through a conformational exploration of all the ligand-protein complexes generated. To do so 1000 steps of conformational search were performed with a hybrid method MCMM/LMCS, which is quick and efficient in the search of possible conformational minima of the energy hypersurface.

The resulting $\alpha, \beta$ I-tubulin or $\alpha, \beta$ III-tubulin-taxane complexes conformations were then evaluated. The free energy of the association was calculated for each complex with the aproximation implemented in Prime (MM-GBSA) ${ }^{43}$. The association free energy values obtained were compared with the biochemically obtained experimental data, in order to validate the modelling results.

The force field OPLS_2005 ${ }^{47}$ was employed in the molecular mechanics calculations. This force field employs a implicit water approximation, thus reducing the calculation time and allowing the building of more complex systems. The solvation method employed was $\mathrm{VSGB}^{48}$. Long and short range extended cutoffs where employed, being the cutoff values $8.0 \AA, 20.0 \AA$ and $4.0 \AA$ for the vdW, electrostatic and H-bonds energies.

The interaction between residue His229 and the azida substituted ligands was 
characterized using semiempiric calculations with Mopac $7.1^{49}$. The benzoyl group with the azide meta substitution and His229 were considered mantaining the geometrical disposition observed in the complexes and the HOMO and LUMO orbitals were calculated using the RM1 method ${ }^{50}$ toobtain the electrostatic potential of the system. The computed atomic charges were obtained using the Mulliken population analysis ${ }^{51,52}$. Finally a molecular mechanics correction (an increase of 14 $\mathrm{kcal} / \mathrm{mol}$ in the rotation energy of $\mathrm{N}$-methyl acetamide) was introduced for the -CO-NH- links when they are a peptide bond.

\section{Microtubule Polymerization Assays and Molecular fingerprint}

The procedures are available in the supplemental materials.

\section{Acknowledgment}

We are indebted to Matadero Vicente de Lucas de Segovia for providing calf brains for the tubulin purification, to Prof. Richard Luduena (University of Texas, USA) for the $\beta$ III transfected cells, to Dr Michel M. Gottesman (NIH, Bethesda USA) for KB-3-1 and KB-V1cells and to P. Lastres for his help with cell cytometry. This research was supported by NSFC (Grant No. 30930108) to (W.-S.F.), and by BIPPED2 (S2010/BMD-2457) (J.F.D.), project of the Comunidad de Madrid and the BIO2013-42984R (to J.F.D.) project from the Ministry of Economy and Competitiveness of Spain.

\section{References}

(1) Dumontet, C.; Jordan, M. A. Microtubule-binding agents: a dynamic field of cancer therapeutics. Nat Rev Drug Discov 2010, 9, 790-803.

(2) Guenard, D.; Gueritte-Voegelein, F.; Potier, P. Taxol and taxotere: discovery, chemistry, and structure-activity relationships. Acc. Chem. Res. 1993, 26, 160-167.

(3) Ojima, I.; Das, M. Recent Advances in the Chemistry and Biology of New Generation Taxoids. J. Nat. Prod. 2009, 72, 554-565. 
(4) Ojima, I.; Lichtenthal, B.; Lee, S.; Wang, C., Wang, X. Taxane anticancer agents: a patent perspective. Expert Opin Ther Patents, 2016, 26, 1-20.

(5) Galletti, E.; Magnani, M.; Renzulli, M. L.; Botta, M., Paclitaxel and docetaxel resistance: molecular mechanisms and development of new generation taxanes. ChemMedChem 2007, 2, 920-942.

(6) Fojo, T.; Coley, H. M. The role of efflux pumps in drug-resistant metastatic breast cancer: new insights and treatment strategies. Clin. Cancer Res. 2007, 7, 749-756.

(7) Kavallaris, M. Microtubules and resistance to tubulin-binding agents. Nat. Rev. Cancer 2010, 10, 194-204.

(8) Kamath, K.; Wilson, L.; Cabral, F.; Jordan, M. A. ßIII-tubulin induces paclitaxel resistance in association with reduced effects on microtubule dynamic instability. J. Biol. Chem. 2005, 280, 12902-12907.

(9) Orr, G. A.; Verdier-Pinard, P.; McDaid, H.; Horwitz, S. B. Mechanisms of Taxol resistance related to microtubules. Oncogene 2003, 22, 7280-7295.

(10) Gan, P. P.; McCarroll, J. A.; Po'uha, S. T.; Kamath, K.; Jordan, M. A.; Kavallaris, M. Microtubule dynamics, mitotic arrest, and apoptosis: drug-induced differential effects of $\beta$ III-tubulin. Mol. Cancer Ther. 2010, 9, 1339-1348.

(11) Monzo, M.; Rosell, R.; Sanchez, J. J.; Lee, J. S.; O'Brate, A.; Gonzalez-Larriba, J. L.; Alberola, V.; Lorenzo, J. C.; Nunez, L.; Ro, J. Y.; Martin, C. Paclitaxel resistance in non-small-cell lung cancer associated with beta-tubulin gene mutations. J. Clin. Oncol. 1999, 17, 1786-1793.

(12) Berrieman, H. K.; Lind, M. J.; Cawkwell, L. Do beta-tubulin mutations have a role in resistance to chemotherapy? Lancet Oncol. 2004, 5, 158-64.

(13) Mesquita, B.; Veiga, I.; Pereira, D.; Tavares, A.; Pinto, I. M.; Pinto, C.; Teixeira, M. R.; Castedo, S. No significant role for beta tubulin mutations and mismatch repair defects in ovarian cancer resistance to paclitaxel/cisplatin. BMC cancer 2005, 5, 101.

(14) Ojima, I.; Borella, C. P.; Wu, X.; Bounaud, P.-Y.; Oderda, C. F.; Sturm, M.; Miller, M. L.; Chakravarty, S.; Chen, J.; Huang, Q.; Pera, P.; Brooks, T. A.; Baer, M. R.; Bernacki, R. J. Design, Synthesis and Structure-Activity Relationships of Novel Taxane-Based Multidrug Resistance Reversal Agents. J. Med. Chem. 2005, 48, 2218-2228.

(15) Ferlini, C.; Raspaglio, G.; Mozzetti, S.; Cicchillitti, L.; Filippetti, F.; Gallo, D.; Fattorusso, 
C.; Campiani, G.; Scambia, G. The seco-taxane IDN5390 is able to target class III $\beta$-tubulin and to overcome paclitaxel resistance. Cancer Res. 2005, 65, 2397-2405.

(16) Pepe, A; Sun, L; Zanardi, I; Wu, X-Y; Ferlini, C, Fontana, G; Bombardelli, E; Ojima, I. Novel C-seco-taxoids possessing high potency against paclitaxel-resistant cancer cell lines overexpressing class Ш $\beta$-tubulin. Bioorg. Med. Chem. Lett. 2009, 19, 3300-3304.

(17) Petrelli, A.; Valabrega, G. Multitarget drugs: the present and the future of cancer therapy. Expert Opin Pharmacother 2009, 10, 589-600.

(18) Zimmermann, G. R.; Lehar, J.; Keith, C. T. Multi-target therapeutics: when the whole is greater than the sum of the parts. Drug Discov. Today 2007, 12, 34-42.

(19) Yang, C. G.; Barasoain, I.; Li, X.; Matesanz, R.; Liu, R.; Sharom, F. J.; Yin, D. L.; Díaz, J. F.; Fang, W. S. Overcoming Tumor Drug Resistance with High-Affinity Taxanes: A SAR Study of C2-Modified 7-Acyl-10-Deacetyl Cephalomannines. ChemMedChem 2007, 2, 691-701.

(20) Wang, H.; Li, H.; Zuo, M.; Zhang, Y.; Liu, H.; Fang, W.; Chen, X. Lx2-32c, a novel taxane and its antitumor activities in vitro and in vivo. Cancer lett. 2008, 268, 89-97.

(21) Zhou, Q.; Li, Y.; Jin, J.; Lang, L.; Zhu, Z.; Fang, W.; Chen, X. Lx2-32c, a Novel Taxane Derivative, Exerts Anti-resistance Activity by Initiating Intrinsic Apoptosis Pathway in Vitro and Inhibits the Growth of Resistant Tumor in Vivo. Biol. Pharm. Bull. 2012, 35, 2170-2179.

(22) St. George. M.; Ayoub. A. T.; Banerjee. A.; Churchill. C. D.; Winter, P.; Klobukowski, M.; Cass, C. E.; Luduena, R. F.; Tuszynski, J. A.; Damaraju, S. Designing and Testing of Novel Taxanes to Probe the Highly Complex Mechanisms by Which Taxanes Bind to Microtubules and Cause Cytotoxicity to Cancer Cells. PloS ONE 2015, 10, e0129168.

(23) Yeh, L. C.; Banerjee, A.; Prasad, V.; Tuszynski, J. A.; Weis, A. L.; Bakos, T.; Yeh, I. T.; Luduena, R. F.; Lee, J. C. Effect of CH-35, a novel anti-tumor colchicine analogue, on breast cancer cells overexpressing the $\beta I I I$ isotype of tubulin. Invest New Drugs 2016, 34, 129-37.

(24) Dumontet, C.; Jordan, M. A.; Lee, F. F. Ixabepilone: targeting betaIII-tubulin expression in taxane-resistant malignancies. Mol. Cancer Ther. 2009, 8, 17-25.

(25) Cai, P.; Lu, P.; Sharom, F. J.; Fang, W. S. A semisynthetic taxane Yg-3-46a effectively evades P-glycoprotein and $\beta$-III tubulin mediated tumor drug resistance in vitro. Cancer lett. 2013, 341, 214-223

(26) Magnani, M.; Ortuso, F.; Soro, S.; Alcaro, S.; Tramontano, A.; Botta, M. The $\beta I / \beta I I I-t u b u l i n$ 
isoforms and their complexes with antimitotic agents. FEBS J. 2006, 273, 3301-3310.

(27) Appendino, G.; Noncovich, A.; Bettoni, P.; Dambruoso, P.; Sterner, O.; Fontana, G.; Bombardelli, E. The Reductive Fragmentation of 7-Hydroxy-9, 10-dioxotaxoids. Eur. J. Org. Chem. 2003, 4422-4431.

(28) Vedejs, E.; Engler, D.; Mullins, M. Reactive triflate alkylating agents. J. Org. Chem. 1977, 42, 3109-3113.

(29) Appendino, G.; Danieli, B.; Jakupovic, J.; Belloro, E.; Scambia, G.; Bombardelli, E., Synthesis and evaluation of C-seco paclitaxel analogues. Tetrahedron Lett. 1997, 38, 4273-4276.

(30) Matesanz, R.; Barasoain, I.; Yang, C. G.; Wang, L.; Li, X.; de Ines, C.; Coderch, C.; Gago, F.; Barbero, J. J.; Andreu, J. M.; Fang, W. S.; Diaz, J. F. Optimization of taxane binding to microtubules: binding affinity dissection and incremental construction of a high-affinity analog of paclitaxel. Chem. Biol. 2008, 15, 573-85.

(31) Matesanz, R.; Rodríguez-Salarichs, J.; Pera, B.; Canales, Á.; Andreu, José M.; JiménezBarbero, J.; Bras, W.; Nogales, A.; Fang, W.-S.; Díaz, José F., Modulation of Microtubule Interprotofilament Interactions by Modified Taxanes. Biophys. J. 2011, 101, 2970-2980.

(32) Prota, A. E.; Bargsten, K.; Zurwerra, D.; Field, J. J.; Díaz, J. F.; Altmann, K.-H.; Steinmetz, M. O., Molecular Mechanism of Action of Microtubule-Stabilizing Anticancer Agents. Science 2013, 339, 587-590.

(33) Matesanz, R.; Trigili, C.; Rodríguez-Salarichs, J.; Zanardi, I.; Pera, B.; Nogales, A.; Fang, W. S.; Jímenez-Barbero, J.; Canales, Á.; Barasoain, I.; Ojima, I.; Díaz, J. F. Taxanes with high potency inducing tubulin assembly overcome tumoural cell resistances. Bioorg. Med. Chem. 2014, 22, 5078-5090.

(34) Chaudhary, A. G.; Gharpure, M. M.; Rimoldi, J. M.; Chordia, M. D.; Kingston, D. G. I.; Grover, S.; Lin, C. M.; Hamel, E.; Gunatilaka, A. A. L. Unexpectedly Facile Hydrolysis of the 2-Benzoate Group of Taxol and Syntheses of Analogs with Increased Activities. J. Am. Chem. Soc. 1994, 116, 4097-4098.

(35) Kowalski, R. J.; Giannakakou, P.; Gunasekera, S. P.; Longley, R. E.; Day, B. W.; Hamel, E. The Microtubule-Stabilizing Agent Discodermolide Competitively Inhibits the Binding of Paclitaxel (Taxol) to Tubulin Polymers, Enhances Tubulin Nucleation Reactions More Potently than Paclitaxel, and Inhibits the Growth of Paclitaxel-Resistant Cells. Mol. Pharmacol. 1997, 52, 
613-622.

(36) Joe, P. A.; Banerjee, A.; Ludueña, R. F. The roles of cys124 and ser239 in the functional properties of human $\beta$ III tubulin. Cell Motil. Cytoskeleton 2008, 65, 476-486.

(37) Buey, R. M.; Barasoain, I.; Jackson, E.; Meyer, E.; Giannakakou, P.; Paterson, I.; Mooberry, S.; Andreu, J. M.; Diaz, J. F. Microtubule Interactions with Chemically Diverse Stabilizing Agents: Thermodynamics of Bindingto the Paclitaxel Site Predicts Cytotoxicity. Chem. Biol. 2005, 12, 1269-1279.

(38) Andreu, J. M. Large Scale Purification of Brain Tubulin With the Modified Weisenberg Procedure. In Methods in Molecular Medicin; Zhou, J., Humana Press: 2007, 137, pp 17-28.

(39) Díaz, J. F.; Barasoain, I.; Andreu, J. M. Fast Kinetics of Taxol Binding to Microtubules: Effects of solution variables and microtubule-associated proteins. J. Biol. Chem. 2003, 278, 8407-8419.

(40) Buey, R. M.; Díaz, J. F.; Andreu, J. M.; O'Brate, A.; Giannakakou, P.; Nicolaou, K. C.; Sasmal, P. K.; Ritzén, A.; Namoto, K. Interaction of Epothilone Analogs with the Paclitaxel Binding Site: Relationship between Binding Affinity, Microtubule Stabilization, and Cytotoxicity. Chem. Biol. 2004, 11, 225-236.

(41) Schrödinger, L. Maestro v9.3; Schröedinger, LCC, New York, NY,2012.

(42) Schrödinger Release 2014-3: Desmond Molecular Dynamics System, version 3.9, Maestro-Desmond Interoperability Tools, version 3.9; Schrödinger, D. E. Shaw Research, New York NY, 2014.

(43) Jacobson, M. P.; Pincus, D. L.; Rapp, C. S.; Day, T. J.; Honig, B.; Shaw, D. E.; Friesner, R. A. A hierarchical approach to all-atom protein loop prediction. Proteins 2004, 55, 351-367.

(44) Lowe, J.; Li, H.; Downing, K. H.; Nogales, E. Refined structure of alpha beta-tubulin at 3.5 A resolution. J. Mol. Biol. 2001, 313, 1045-1057.

(45) Halgren, T. A. Identifying and Characterizing Binding Sites and Assessing Druggability. $J$ Chem Inf Model 2009, 49, 377-389.

(46) Schrödinger Release 2014-3: MacroModel, version 10.5; Schrödinger, LLC, New York, NY, 2014.

(47) Banks, J. L.; Beard, H. S.; Cao, Y.; Cho, A. E.; Damm, W.; Farid, R.; Felts, A. K.; Halgren, T. A.; Mainz, D. T.; Maple, J. R.; Murphy, R.; Philipp, D. M.; Repasky, M. P.; Zhang, L. Y.; Berne, 
B. J.; Friesner, R. A.; Gallicchio, E.; Levy, R. M. Integrated Modeling Program, Applied Chemical Theory (IMPACT). J Comput Chem 2005, 26, 1752-1780.

(48) Li, J.; Abel, R.; Zhu, K.; Cao, Y.; Zhao, S.; Friesner, R. A. The VSGB 2.0 Model: A Next Generation Energy Model for High Resolution Protein Structure Modeling. Proteins 2011, 79, $2794-2812$.

(49) James, J. P. S. MOPAC 2012; Stewart Computational Chemistry, Colorado Springs, CO, USA, 2012; HTTP://OpenMOPAC.net.

(50) Rocha, G. B.; Freire, R. O.; Simas, A. M.; Stewart, J. J. P. RM1: A reparameterization of AM1 for H, C, N, O, P, S, F, Cl, Br, and I. J Comput Chem 2006, 27, 1101-1111.

(51) Mulliken, R. S. Electronic Population Analysis on LCAO-MO Molecular Wave Functions. I. J Chem Phys 1955, 23, 1833-1840.

(52) Csizmadia, I. G. Theory and Practice of MO Calculations on Organic Molecules (Progress in theoretical organic chemistry); Elsevier, Amsterdam, 1976. 


\section{Figure legends}

Figure 1. Structures of Paclitaxel, Cabazitaxel Docetaxel, IDN5390 and LX2-32C

Figure 2. Structures of taxoids $\mathbf{1 k}$ and $\mathbf{1 l}$

Figure 3. Representation of the HOMO (A), LUMO (B) and the Poisson-Boltzmann electrostatic surface $(\mathrm{C}, \mathrm{D})$ of the $\mathrm{H} 229$ of tubulin and the azide m-benzoate of the taxanes. The H229 is represented in gray carbons while azide m-benzoate is represented in cian carbons. Both molecules are represented in ball and stick. Electrostatic surface in blue represents positive charge, while electrostatic surface in red represents negative charge.

Figure 4. Structures of taxoids $\mathbf{1 m} \sim \mathbf{1 0}$

Figure 5. Time course of polymerization for vehicle (black line), paclitaxel (red line), $\mathbf{1 k}$ (green line), $1 \mathbf{l}$ (blue line), 1m (dashed black line), 1n (dashed red line), 10 (dashed green line) measured by turbidimetry at $350 \mathrm{~nm}$. Microtubule protein: $20 \mu \mathrm{M}$ in $10 \mathrm{mM}$ sodium Phosphate, $1 \mathrm{mM}$ EDTA and $4 \mathrm{mM} \mathrm{MgCl}_{2}$; GTP: $1 \mathrm{mM}$; drug: 25 $\mu \mathrm{M} ; 37^{\circ} \mathrm{C}$.

Figure 6. Effect of taxoids $1 \mathbf{k - o}$ on the cell cycle of of Hela and Hela- $\beta$ III. Cells were incubated for $20 \mathrm{~h}$ with either drug vehicle DMSO (control cells) or with serial concentrations of each drug. The concentrations shown are those at which the maximal accumulation of cells in the $\mathrm{G}_{2} / \mathrm{M}$ phase was observed. 
Figure 1

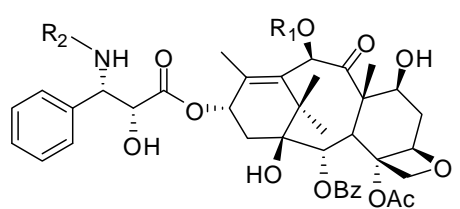

Paclitaxel $R_{1}=A c, R_{2}=B z$

Docetaxel $R_{1}=H, R_{2}=B o c$

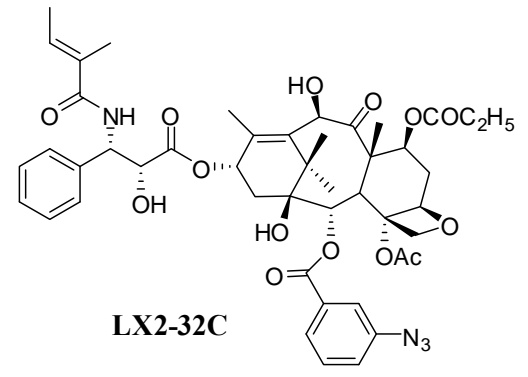

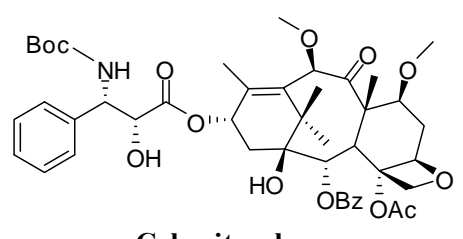

Cabazitaxel

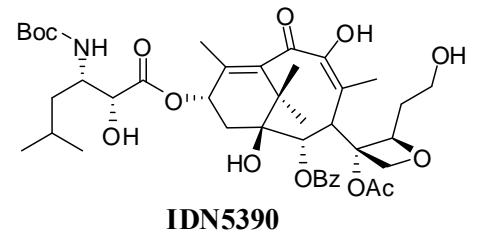


Figure 2

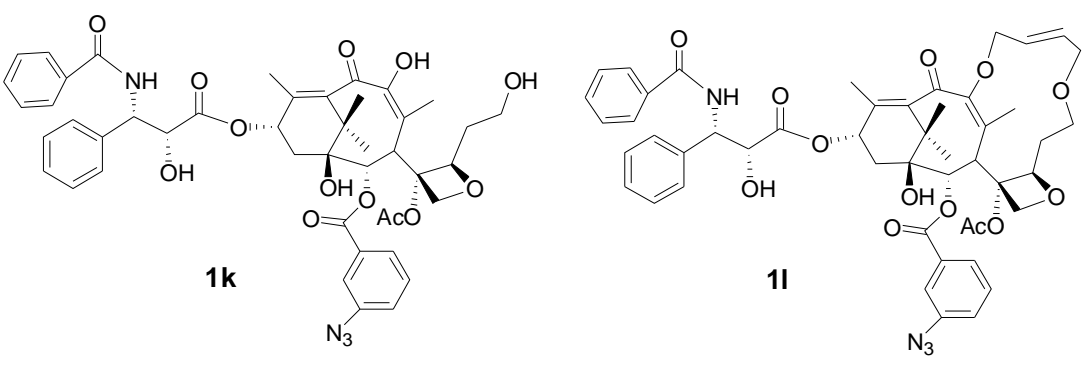


Figure 3

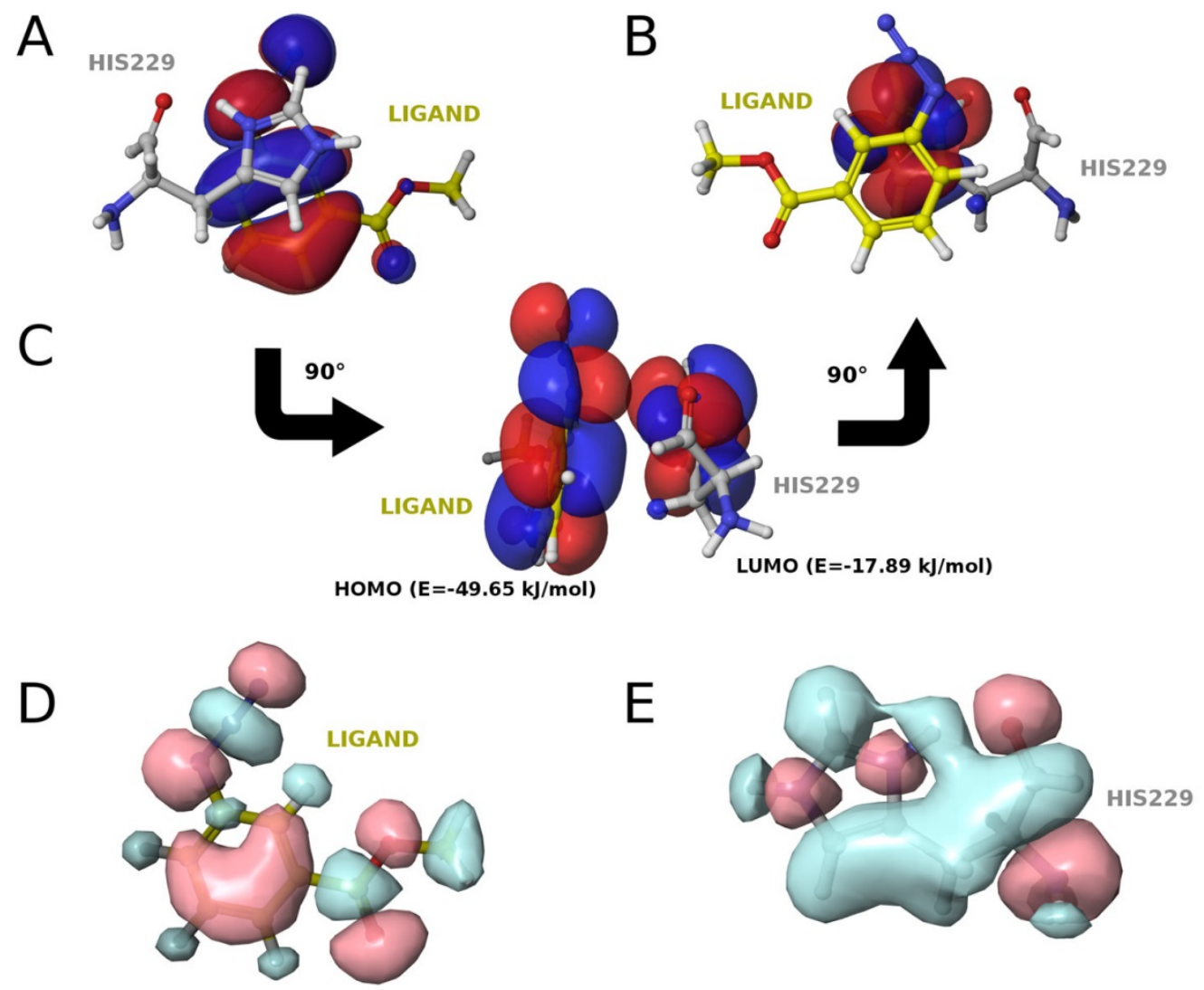


Figure 4

$$
\text { (Im R=OMe }
$$


Figure 5

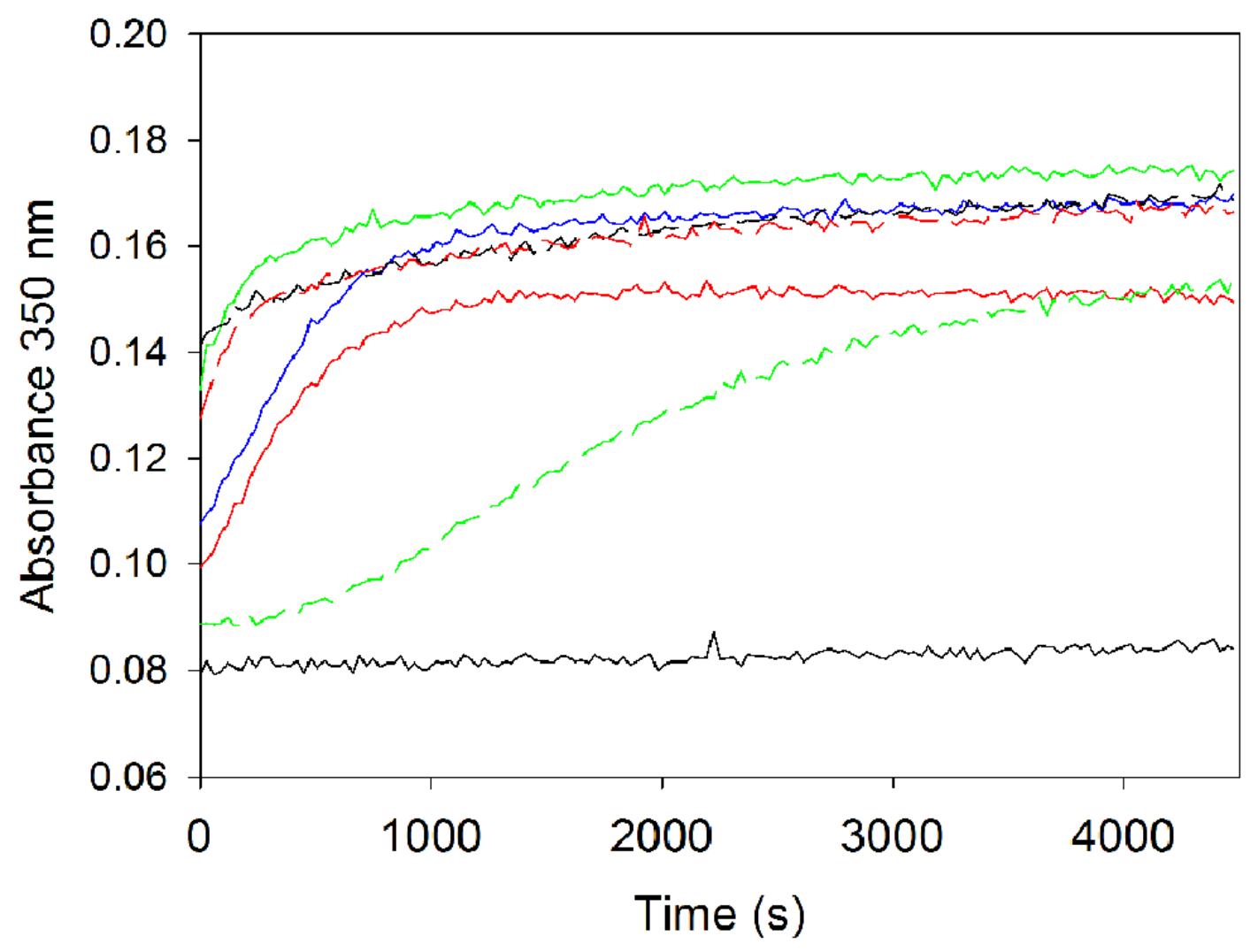


Figure 6

Hela

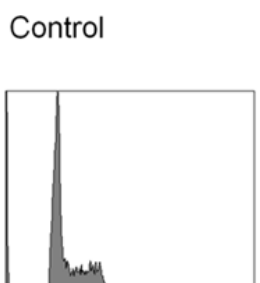

$20 \mathrm{nM} 1 \mathrm{k}$

$15 \mathrm{nM} 1 \mathrm{~m}$

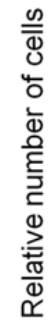

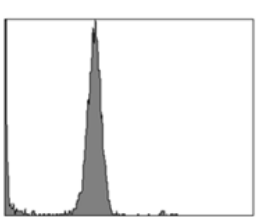

Hela $\beta$-III

Control

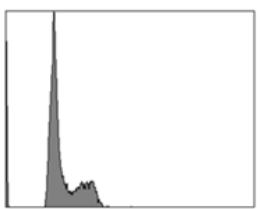

$15 \mathrm{nM} 1 \mathrm{~m}$

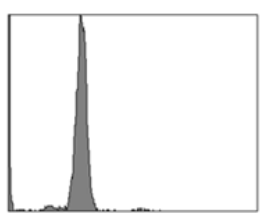

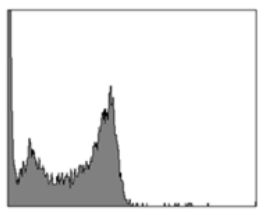

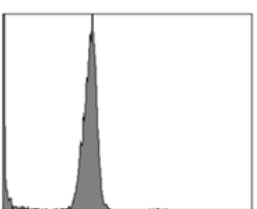

$10 \mathrm{nM} 1 \mathrm{n}$

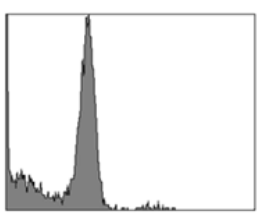

35 nM Paclitaxel

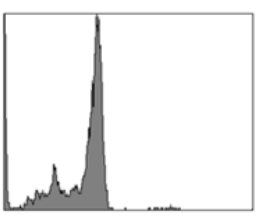

$20 \mathrm{nM} 1 \mathrm{n}$
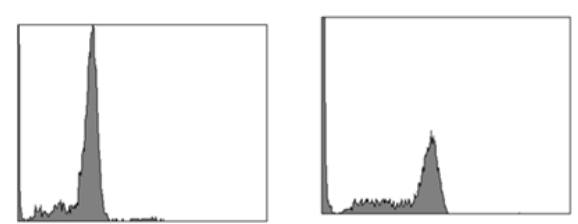

Relative DNA content (PI fluorescence)

$25 \mathrm{nM} 10$

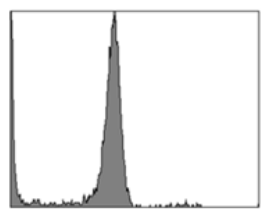

$55 \mathrm{nM} 1 \mathrm{k}$

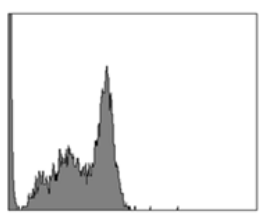

$80 \mathrm{nM} 10$

$15 \mathrm{nM} 11$

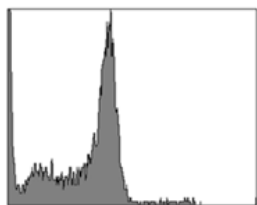

$25 \mathrm{nM} 11$

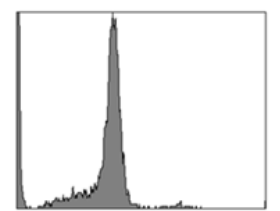

\section{)}


Table 1 Cytotoxicity and Binding Affinity to Microtubules of Taxoids 1a-j

\begin{tabular}{|c|c|c|c|c|c|c|c|}
\hline \multirow{2}{*}{ Compounds } & \multicolumn{2}{|c|}{ Cytotoxicity $\left(\mathrm{IC}_{50}, \mathrm{nM}\right)$} & \multirow{2}{*}{$\begin{array}{l}\text { Ratio } \\
\mathrm{R} / \mathrm{S}\end{array}$} & \multicolumn{2}{|c|}{ Cytotoxicity $\left(\mathrm{IC}_{50}, \mathrm{nM}\right)$} & \multirow{2}{*}{$\begin{array}{l}\text { Ratio } \\
\mathrm{R} / \mathrm{S}\end{array}$} & \multirow{2}{*}{$\begin{array}{c}\text { Binding Affinity } \\
\left(35^{\circ} \mathrm{C} \cdot \mathrm{x} 10^{7} \mathrm{M}^{-1}\right) \\
\mathrm{Kb} / \mathrm{Kb}\left(\text { paclitaxel }{ }^{*}\right)\end{array}$} \\
\hline & Hela & Hela- $\beta$ III & & A 2780 & A2780AD & & \\
\hline 1a & $3.5 \pm 0.2$ & $26 \pm 5$ & 7.5 & 22.3 & 1719 & 77.1 & 0.96 \\
\hline $1 b$ & $27.9 \pm 0.5$ & $158 \pm 31$ & 5.7 & & & & 0.23 \\
\hline $1 c$ & $126 \pm 16$ & $282 \pm 19$ & 2.2 & & & & 0.17 \\
\hline 1d & $8 \pm 3$ & $58 \pm 4$ & 6.9 & & & & 0.89 \\
\hline $1 \mathrm{e}$ & $3.3 \pm 0.4$ & $20 \pm 7$ & 6.0 & 25.4 & 1395 & 55.0 & 1.30 \\
\hline 1f & $22.0 \pm 0.3$ & $118 \pm 13$ & 5.3 & & & & 0.61 \\
\hline $1 g$ & $6.7 \pm 0.9$ & $34 \pm 6$ & 5.1 & 25.1 & 2194 & 87.4 & 0.96 \\
\hline $1 h^{27}$ & $192 \pm 14$ & $2982 \pm 127$ & 15.6 & 282 & $>10000$ & $>35.4$ & 0.10 \\
\hline $1 \mathbf{i}$ & $312 \pm 44$ & $3842 \pm 4$ & 12.3 & & & & n.d. \\
\hline $\mathbf{1 j}$ & $30 \pm 5$ & $226 \pm 9$ & 7.6 & & & & n.d. \\
\hline paclitaxel & $1.3 \pm 0.2$ & $25 \pm 5$ & 19.6 & 6 & 4554 & 759 & 1.00 \\
\hline
\end{tabular}

$*$ Kb for paclitaxel is $0.56 \times 10^{7} \mathrm{M}^{-1}$.

Table 2 Cytotoxicity of taxoid 1e and paclitaxel in Hela- $\beta$ III tumor cells

\begin{tabular}{ccc}
\hline Compouds & \multicolumn{2}{c}{$\begin{array}{c}\text { Cytotoxicity }\left(\mathrm{IC}_{50 .} \mathrm{nM}\right) \\
\text { SiRNA }^{\mathrm{b}}\end{array}$} \\
\hline 1e & $13.3 \pm 1.4$ & $9.0 \pm 1.1$ \\
paclitaxel & $19.7 \pm 0.7$ & $5.2 \pm 0.9$ \\
\hline
\end{tabular}

a: In the absence of $\beta$ III tubulin siRNA.

$\mathrm{b}$ : In the presence of $\beta$ III tubulin siRNA. 
Table 3 Cytotoxicity and Binding Affinity to MTs of Taxoids 1k-o

\begin{tabular}{|c|c|c|c|c|c|c|c|c|c|c|}
\hline \multirow{2}{*}{ Compounds } & \multicolumn{2}{|c|}{ Cytotoxicity $\left(\mathrm{IC}_{50}, \mathrm{nM}\right)$} & \multirow{2}{*}{$\begin{array}{l}\text { Ratio } \\
\text { R / S }\end{array}$} & \multicolumn{2}{|c|}{ Cytotoxicity $\left(\mathrm{IC}_{50}, \mathrm{nM}\right)$} & \multirow{2}{*}{$\begin{array}{l}\text { Ratio } \\
\text { R / S }\end{array}$} & \multicolumn{2}{|c|}{ Cytotoxicity $\left(\mathrm{IC}_{50}, \mathrm{nM}\right)$} & \multirow{2}{*}{$\begin{array}{c}\text { Ratio } \\
\text { R/S }\end{array}$} & \multirow{2}{*}{$\begin{array}{c}\text { Binding Affinity } \\
\left(35^{\circ} \mathrm{C}, \times 10^{7} \mathrm{M}^{-1}\right) \\
\mathrm{Kb} / \mathrm{Kb}\left(\text { paclitaxel }^{*}\right)\end{array}$} \\
\hline & Hela & Hela- $\beta$ III & & A2780 & A2780AD & & KB (Hela) & KB-V1 & & \\
\hline $\mathbf{1 k}$ & $1.0 \pm 0.3$ & $209 \pm 38$ & 209 & $1.6 \pm 0.6$ & $>5000$ & -- & $5.1 \pm 0.1$ & $5100 \pm 1000$ & 1000 & 1.18 \\
\hline 11 & $0.7 \pm 0.2$ & $45 \pm 12$ & 64 & $2.8 \pm 0.7$ & $32 \pm 14$ & 11.4 & $15 \pm 05$ & $94 \pm 30$ & 6.2 & 1.15 \\
\hline $1 \mathrm{~m}$ & $3.3 \pm 0.5$ & $33 \pm 7$ & 10 & $4.3 \pm 1.2$ & $893 \pm 233$ & 207 & $6.6 \pm 2$ & $255 \pm 100$ & 38.7 & 0.132 \\
\hline 1n & $0.9 \pm 0.6$ & $19 \pm 4$ & 21 & $4.1 \pm 2.6$ & $96 \pm 44$ & 23.4 & $5.2 \pm 2$ & $503 \pm 200$ & 97 & 2.17 \\
\hline 10 & $2.14 \pm 0.07$ & $72 \pm 20$ & 33.6 & $5.1 \pm 0.2$ & $1425 \pm 519$ & 279 & $2.9 \pm 2$ & $3400 \pm 1000$ & 1172 & 1.28 \\
\hline paclitaxel & $1.1 \pm 0.4$ & $34 \pm 9$ & 31.8 & $1.07 \pm 0.05$ & $1282 \pm 44$ & 1198 & $1.9 \pm 1$ & $9800 \pm 4000$ & 5157 & 1.00 \\
\hline
\end{tabular}

$* \mathrm{~Kb}$ for paclitaxel is $2.5 \times 10^{7} \mathrm{M}^{-1}$.

Table 4 Critical concentrations of ligand-induced tubulin assembly

\begin{tabular}{ccccccc}
\hline Compounds & DMSO & paclitaxel & $\mathbf{1 k}$ & $\mathbf{1 1}$ & $\begin{array}{c}1 \mathrm{~m} \\
\mathbf{1 0}\end{array}$ \\
\hline $\begin{array}{c}\mathrm{Cr}(\mu \mathrm{M}) \pm \\
\mathrm{StdErr}\end{array}$ & $>20$ & $5.36 \pm 1.04$ & $3.82 \pm 0.13$ & $2.34 \pm 0.10$ & $3.20 \pm 0.07$ & $3.63 \pm 1.00$ \\
\hline
\end{tabular}


Table of Contents graphic

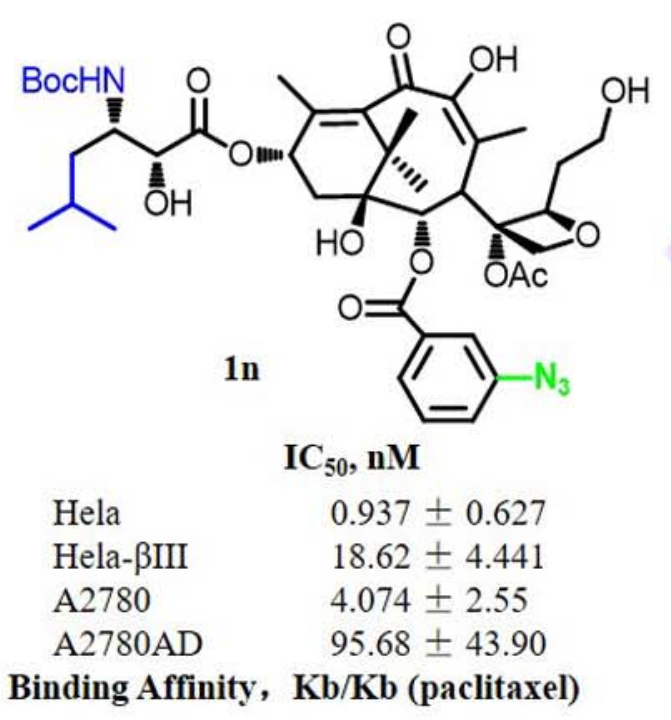

2.17

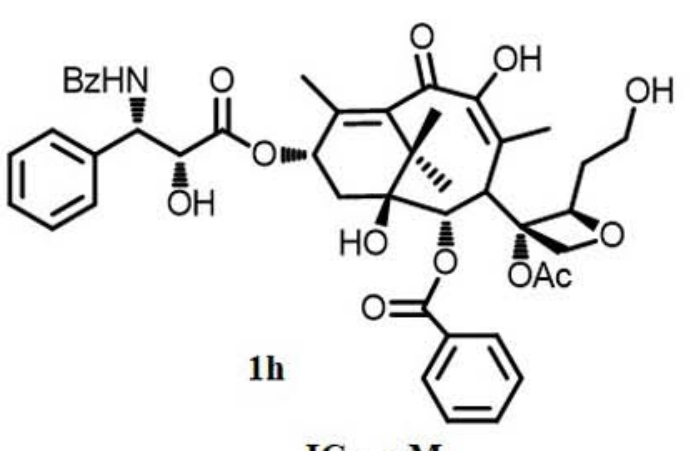

$\mathrm{IC}_{50}, \mathrm{nM}$

$\begin{array}{ll}\text { Hela } & 191.5 \pm 13.9 \\ \text { Hela- } \beta \text { III } & 2981.52 \pm 126.6 \\ \text { A2780 } & 282 \\ \text { A2780AD } & >10000\end{array}$

Binding Affinity, Kb/Kb (paclitaxel)

0.10

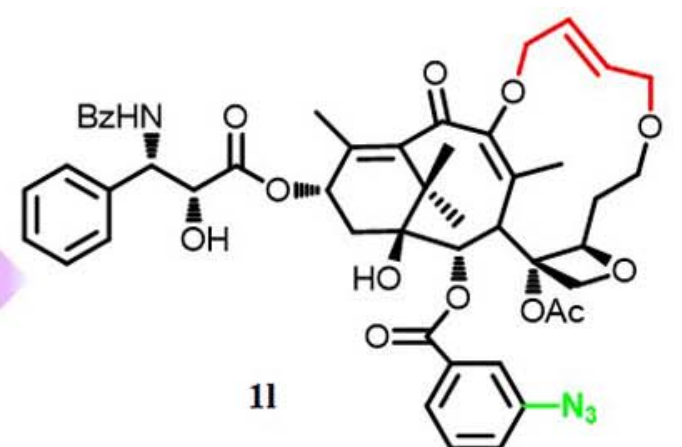

IC $_{50}, \mathbf{n M}$

Hela

Hela- $\beta$ III

A2780

A2780AD

$0.661 \pm 0.199$

$45.31 \pm 12.46$

$2.814 \pm 0.666$

$31.75 \pm 14.24$

Binding Affinity, $\mathbf{K b} / \mathbf{K b}$ (paclitaxel)

1.15 